\title{
الإعلام الرقميّ وواقع التربية الإعلاميّة في الأردن
}

\section{Digital media and the reality of media education in Jordan}

ع عدنان الزعبي

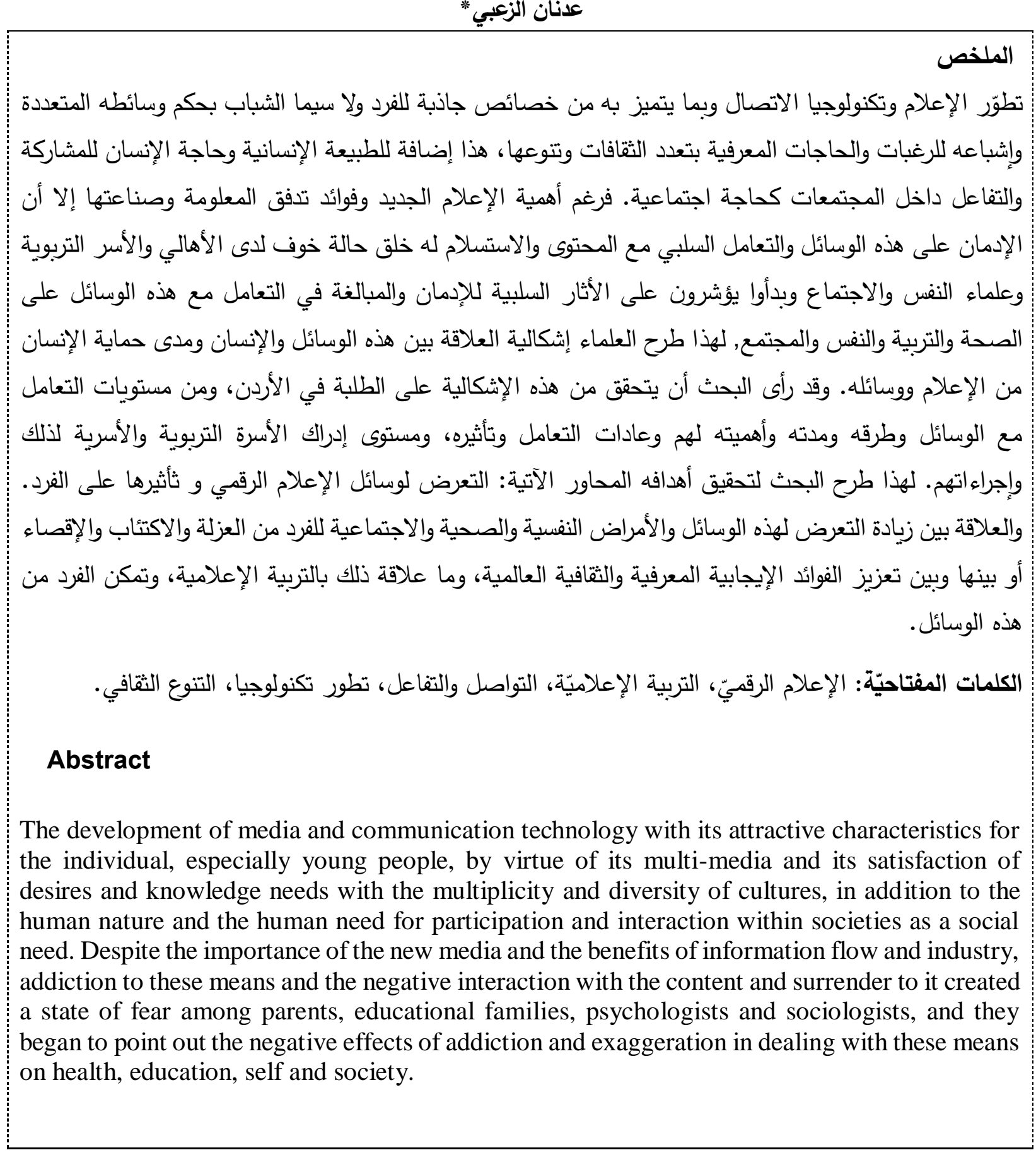


For this reason, scholars have raised the problem of the relationship between these means and humans and the extent to which humans are protected against the different outlets of Media. The research sought to verify this problem on students in Jordan, and the levels of dealing with means, methods, duration and importance to them, the habits of dealing and its impact, and the level of awareness of the educational family about this and their procedures. For this reason, the research presented the following themes to achieve its objectives: Exposure to digital media and its impact on the individual, the relationship between increased exposure to these means and psychological, health and social diseases of the individual: isolation, depression and exclusion, or between them and the promotion of positive global cognitive and cultural benefits, and what is the relationship of this with media education, and the individual's comptence thereof.

Key Words: Digital Media, Media Education, Communication and Interaction, Technological Advancement, Cultural Diversity

المقدمة

لا يستطيع الإنسان الاستغناء عن الاتصال أو تجاهله بوصفه أساس بناء العلاقات الإنسانية وبناء التفاعل بين بني البشر وفي مختلف نواحي الحياة. وبمقدار ما توسع الإنسان في عملية التواصل تتسع قاعدة المعرفة لديه، وتعززت الثمولية والتشاركية والانفتاح على مختلف ثقافات الأمم والمعرفة العالمية الثاملة. زادت أهمية الإعلام في العملية الاتصالية نظرًا للدور الكبير الذي لعبته في الفلسفة التربوية تعلمًا وتربية واعدادًا، ورفعت من مستوى التعرض للمعرفة بأساليب وأدوات أقرب إلى رغبة وحواس الفرد، مما عكس أثر الإعلام والتواصل

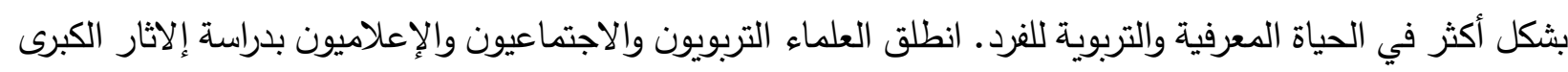

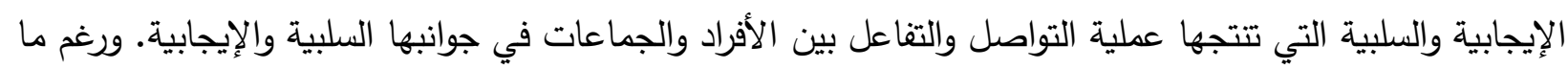
أحدثه هذا التواصل من إيجابيات خاصة في التقدم التكنولوجي الاتصالي الرقمي إلا أن السلبيات التي أحدثتها كانت

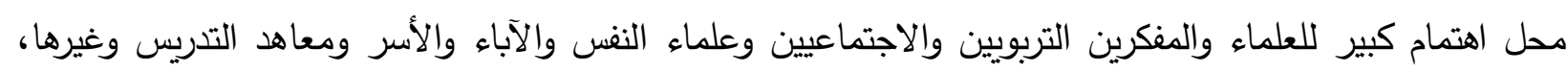
مركزين على:

- الاستغلال الخاطيء أو الاستقبال الخاطيء للمعلومة. - ضعف التعامل مع التدفق الكبير للمعلومات التي توفرها الثبكات الاتصالية العالمية . بعد تطور تكنولوجيا الاتصال وظهور علم الإنترنت الذي فتح المجال لأفراد المجتمع الانساني وسط فضاء مفتوح تجاوز حدود الزمان والمكان, وأضعف من قدرة الدول والحكومات والرقابة من فرض سيطرتها وتحكمها بالمعلومة

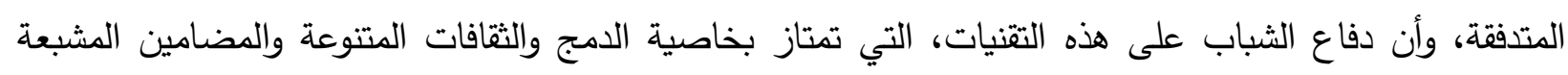

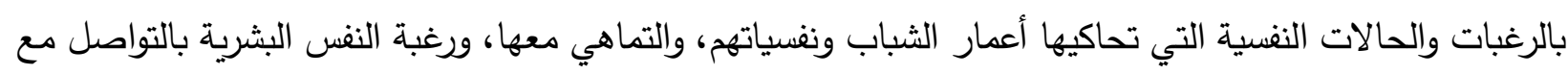

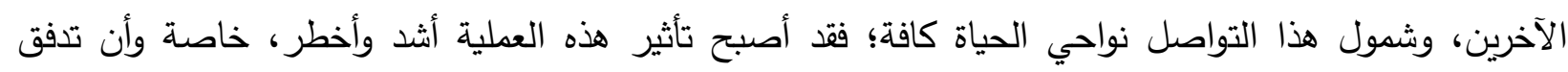

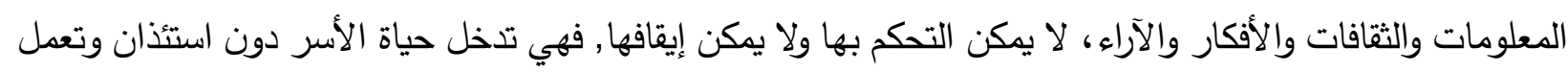


- تسهم في اختلاط مفاهيم وقيم قد لا تكون منسجمة مع تعالمينا وأخلاقياتنا وعاداتنا، مما يؤدي إلى إنعكاس ذلك على السلوك اليومي الأسري والاجتماعي، والتأثير السلبي على المفاهيم والقيم التربوية , والسلوكيات الأسرية

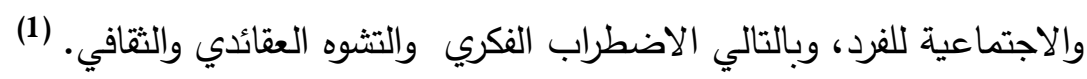

\section{: 1-}

عندما نتحدث عن تعزيز القيم النبيلة والمثل والتعليم وتعديل السلوكيات السلبية، وقبلها التصدي للأفكار التي لا تتلاءم مع واقع مجتمعنا وأخلاقياتنا, والقيام بمعالجة ذلك ببيان ما هو مفيد وما هو غير مفيد، وسط واقع امتاز بتدفق ثقافي

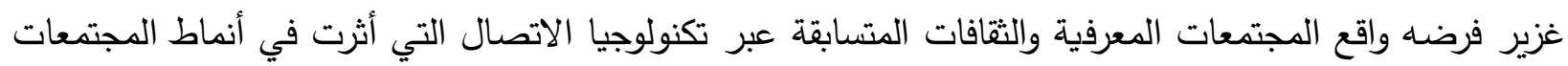

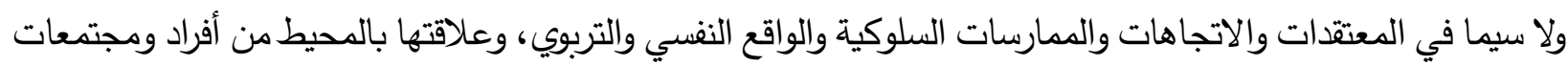
وأسر ، فقد أظهر ذلك أهمية العلاقة بين التربية والإعلام بوصفهما خطابًا جماعيًا وأدوات تربوية وتعليم وتوعية وتثقيف وعيف تسعى لتصويب التجاوزات، وتعزيز الإيجابيات وبيان الفرق بين ما هو مفيد وما هو غير مفيد من منظور قيمي ديني

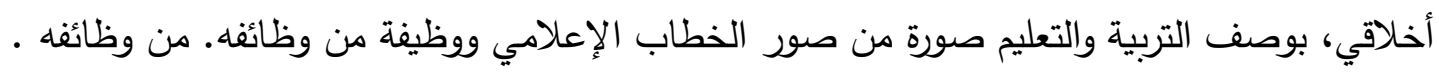
ولعل السؤال الأهم في إثكالية العلاقة بين الإعلام الرقمي والتدفق الثقافي الذي يوفره، وأثره في الفرد أينما يسكن من وحيثما يعيش هو : من يحمي الإنسان ؟، ومن يحافظ عليه من مخاطر الإدمان على هذه التقنيات، وما تحمله من ثقافات وأفكار وآراء؟. ومن يحمي الأفراد والمجتمعات من سيطرة مراكز القوى وأصحاب الأجندات السياسية والمالية والفكرية،؛ وسط فضاء مفتوح متاح لمن يملك الأدوات. وكيف نحمي أنفسنا وأبناءنا ومجتمعاتنا من الأخطار الصحية والنفسية والاجتماعية والتربوية التي يفرضها واقع الاتصال الرقمي ؟ في الوقت الذي لا نريد أن نشهد ردة فعلٍ تتاقضيةٍ

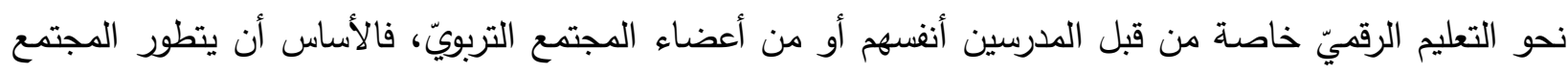
التربوي وأن يكون رائدا للتغيير والتطوير والتأهيل والتمكين ليخرج بنوعية طلبة قادرين على النقد والتمييز مبادرين في التحليل للاستفادة والتطور ـ؟ بكون واندين

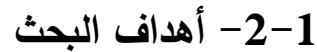

تقوم أهداف البحث على ما يريد الباحث تحقيقه في هذه الدراسة ومنها: التعرف على أهمية الإعلام الرقمي وفوائد تفاعل الأفكار والثقافات بين الأفراد والمجتمعات. التعرف على الجوانب السلبية والإيجابية لتدفق المعلومات وسط لإني المجتمعات الافتراضية والفضاء المفتوح. ومن ثم التعرف على الأمراض النفسية والصحية والتربوية والاجتماعيّة المترتبة على إدمان التقنيات الرقمية. والتعرف على نسب استخدام شرائح الطلبة لتقنيات الإعلام الرقمي وأولويات الاستخدام.

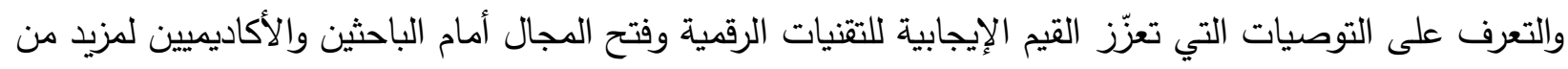
الدراسات والأبحاث حول الإعلام الرقمي. 
- - 1- أهمية البحث

تكمن أهمية البحث فيما يراه الباحث من أن التربية من خلال الإعلام أحد أنماط التربية، التي تقوم على الخطاب الجماعي. حيث تسعى الاستراتيجيات الوطنية والدولية التربوية والإعلامية إلى تأسيس منهج للتربية الإعلامية الهادفة،

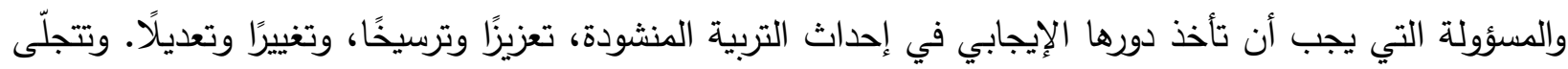
أهمية التربية الإعلامية في : التهوله التركيز على ترسيخ القيم الإيجابية وتقويتها، وكذلك التعديل في القيم السلبية أو تغييرها، وللتربية من خلال الإعلام وسائل ومنطلقات، ويترتب عليها نتائج ايضًا. تضم مناهج التربية الإعلامية التي تم تطويرها مؤخرًا مضامين المجتمع المعلوماتي المتدفقة بما تشمله من ثقافات متتوعة، الأمر الذي يتوجب علينا التأقلم مع هذا التطور والاستفادة من ما تقدمه التكنولوجيا الرقمية، وبالتالي دراسة التربية الإعلامية والرقمية. إن هذا الحقل المعرفي هو اتجاه عالمي جديد، يختص بتعليم أفراد الجمهور مهارة التعامل

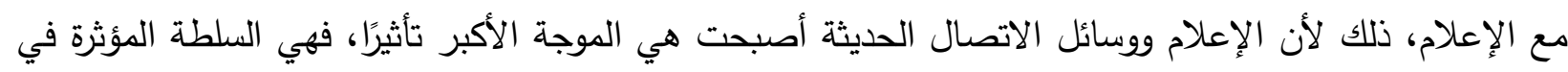
القيم والمعتقدات والتوجهات والممارسات، ويجب التسليم بحقيقة الاعتراف بأن وسائل الإعلام هي بحد ذاتها شكلًا من أشكال التعليم، لا سيما في المجتمعات المعاصرة.

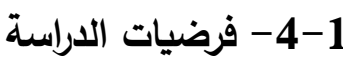

$$
\text { تقوم الفرضية الرئيسية على : }
$$

1-4-1- زيادة التعرض لوسائل الاتصال الرقمي يزيد في مستوى التأثر من مضامينها، وقد انبثق عنها الفرضيات

1-4- 2- تسهم وسيلة الإعلام الرقمي الأكثر استخداما في زيادة وعي طلبة المدارس والجامعات بالأثار السلبية. 1-4-3- تزيد زيادة فترة التعرض لإحدى تقنيات الإعلام الرقمي من فرص الأصابة بأمراض الإعلام الرقمي النفسية والاجتماعية. 1-4-4- يعزز التعامل الصحي للتقنيات الرقمية وفي فترات مناسبة الفوائد الإيجابية لها ولا سيما المعرفة بالثقافات

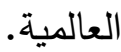
1-4-5- يرتبط توسع ثقافة الفرد العالمية (الدولية ) بثقافته الإعلام الرقمي وتقنياته.

1-4-6 - يمكن اختيار وسائل الإعلام المناسبة لإشباع المعرفة الفرد من مواجهة تحديات المستقبل الرقمية.

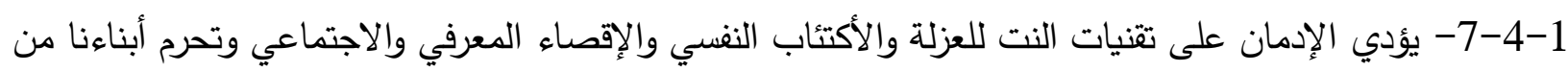
مواجهة المستقبل. 1-4-8- يعزز تعمّق ثقافة الطالب بالتربية الإعلامية قدرة الطلبة على النقد والاستجابة الإيجابية.

1-5-1-1- هل يزيد التعرض لوسائل الإعلام الرقمي من ثأثيرها في الفرد ؟ هأ 1-5-2- هل تسهم وسيلة الإعلام الرقمي الأكثر استخداما في زيادة وعي طلبة المدارس والجامعات بالأثار السلبية لوسائل الإعلام؟ 
1-5-3- هل تتوقف زيادة فرص الأصابة بالأمراض النفسية والصحية على زيادة فترة التعرض لإحدى تقنيات الإعلام

1-5-4- هل يعزز التعامل الصحي للتتنيات الرقمية وفي فترات ونوعية مناسبة الفوائد الإيجابية لها ولا سيما المعرفة

بالثقافات العالمية؟

1-5-5-5- هل يرتبط توسع ثقافة الفرد العالمية (الدولية ) بثقافته الإعلامية الرقمية وتتنياتها ؟

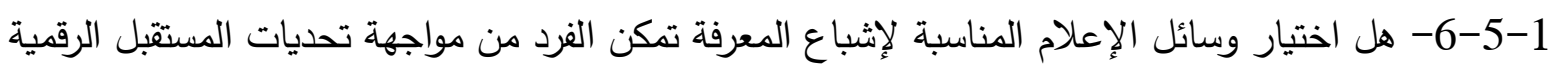

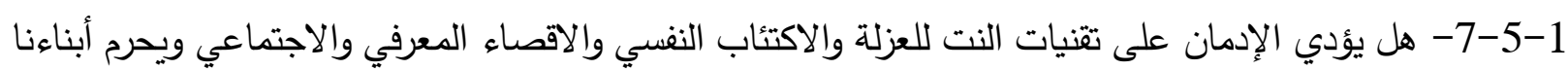

من مواجهة المستقبل؟

1-5-8-8 هل يعزز تعمّق الطالب بثقافة التربية الإعلامية قدرته على النقد والاستجابة الإيجابية.

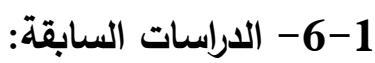
لقد أدى ظهور التأثيرات الكبيرة لوسائل الإعلام، ولا سيما الرقمية، وانعكاس ذلك على حياة وممارسات الأفراد

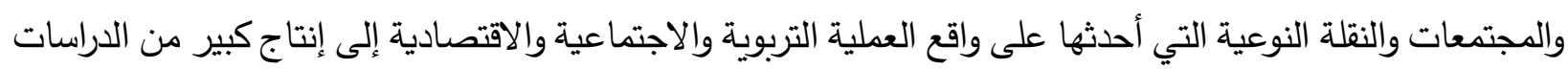

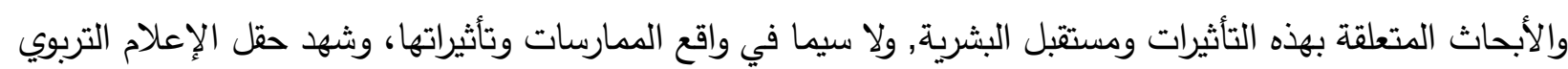

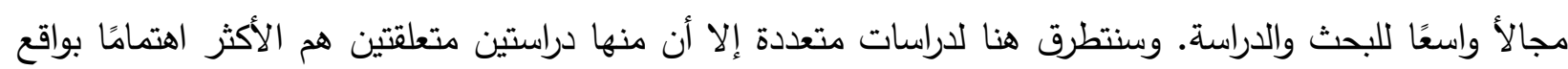

1-1-6-1 الدراسة الأولى: ( تأثير تدريس التربية الإعلامية كمنهج للتدريس حارث محمد الخيول، 2016)

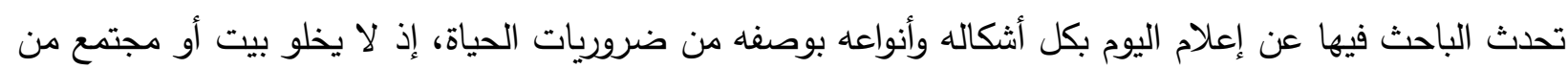

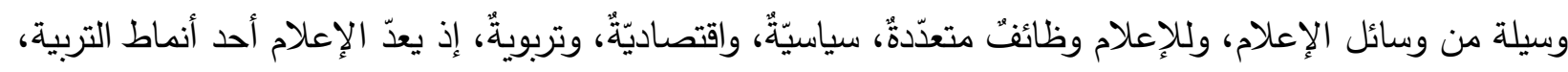

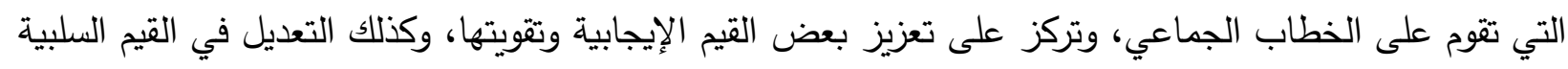

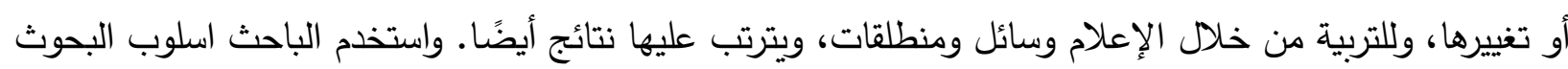

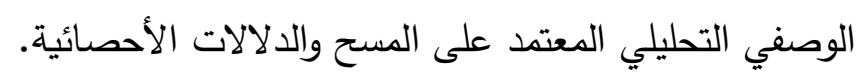

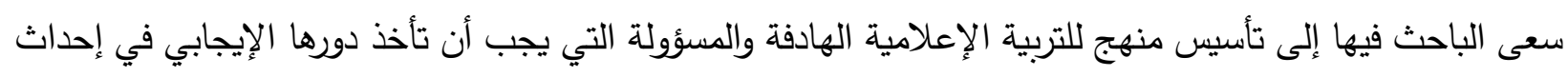

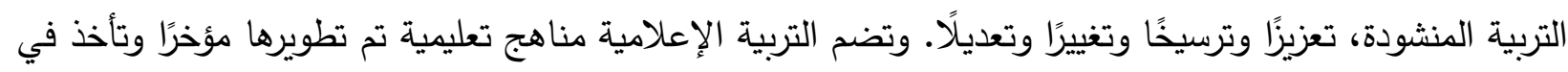

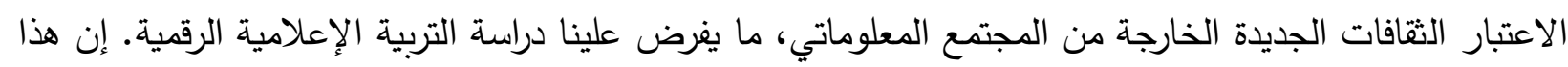

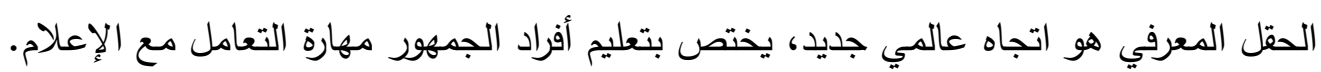

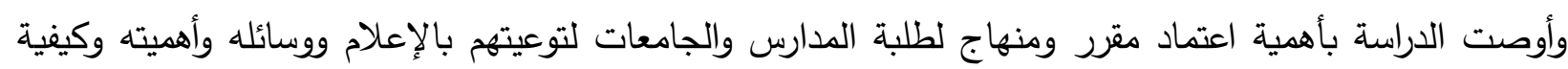

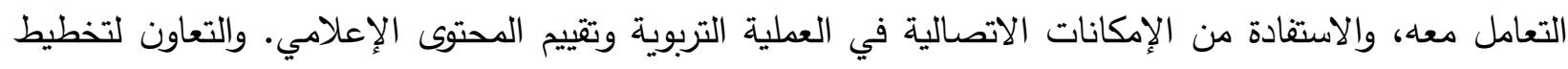
المحتوى الإعلامي للطلبة، وتعزيز دور الطلبة للمساهمة في بناء الثقافة العالمية وفقا للثقافة العربية والاسلامية.

المقاربة مع دراستنا

يقوم هذا البحث في الأساس من أهمية الإعلام ودوره في غرس المعرفة وتعزيز الثقافة وإحداث التعليم والتربية ضمن

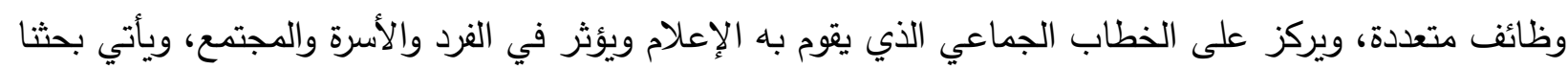

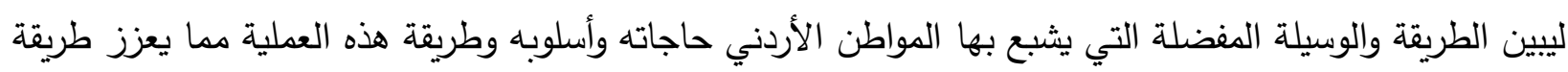
رسم المنهجية في إحداث التأثير في المواطنين. 


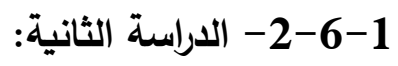

(التربية الإعلامية والمعلوماتية في الأردن، 2016، شيرين صبحي نيل البنا وباسم الطويسي/ معهذ الإعلام الأردني ) تهلف إلى توفير إطار معرفي ومعلوماتي مرجعي لمخططي وصناع القرار السياسي والباحثين والمشرعين، والمهتمين بهذا الموضوع، واعتباره مرجعيات للحديث التربوي الإعلامي المتعلق بذلك، وإبراز أهمية تبني المؤسسات التعليمية

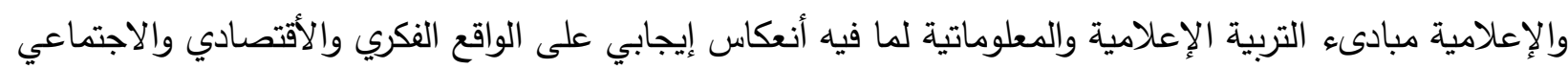

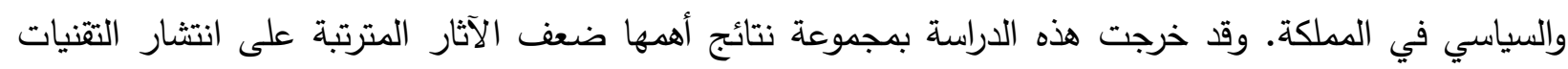
الرقمية ولا سيما انعكاسها الإيجابي على المجتمع كمرفة وتتوع ثقافي, وإطار عام توحيدي، وقاعدة نقدية إبداعية منهجية في التعامل مع المدخلات الجديدة. وبينت الدراسة أهمية إدخال ودمج الإعلام الرقمي بتقنياته في المنهج التعليمي لتعزيز مجتمعات المعرفة فهو في الأردن ضعيف. وترجمة الدستويات العالية من استخدامات هذه التقنيات في المملكة (70\%أن ترنت، 147\% هواتف..) إلى ممارسات ممنهجة تعزز الانفتاح والممارسة الديمقراطية، واحترام الرأي الآخر وتمحيص المعلومة والبحث عن الحقيقة وترسيخ مجتمع المحبة والتقارب ونزع الكراهية والفوضى..إلخ.

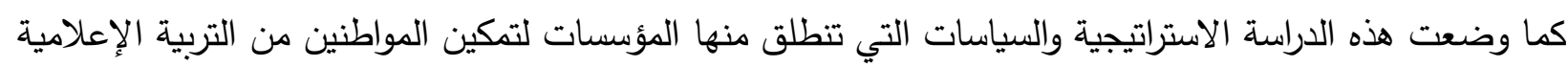
والمعلوماتية.

\section{مقاربة مع دراستنا}

هدفت هذه الدراسة لتوفير إطار معرفي لصناعة التربية الإعلامية بهدف وضح المناهج وتوفير الأدوات وتهيئة القائمين

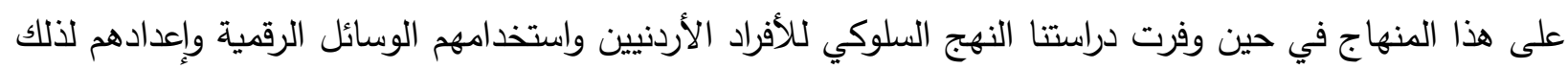
مما يوفر حصيلة قوية ومعرفة واقعية لكيفية توجيه المنهاج والأدوات التربوية. 1-6-3-1 دراسة (3) - الإعلام والتربية الإعلامية ودورها في تتمية الوعي الأجتماعي لاعى طلبة وطالبات المرحلة للاكتور عوض الله، عصام الدين برير آدم .عميد كلية التربية، جامعة أم درمان الإسلامية، 2011، مجلة التربية

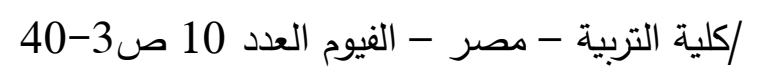

هدفت الدراسة إلى التعرف على واقع الإعلام التربوي في السودان، وأهمية التربية الإعلامية لطلبة الددارس والوقوف

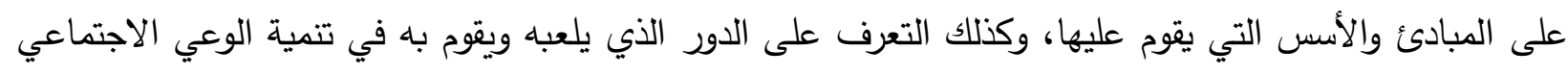

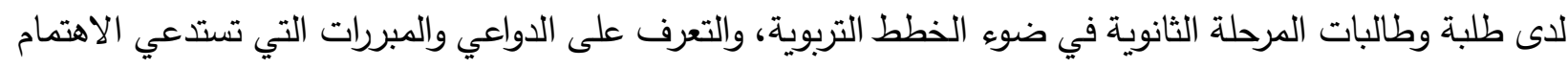

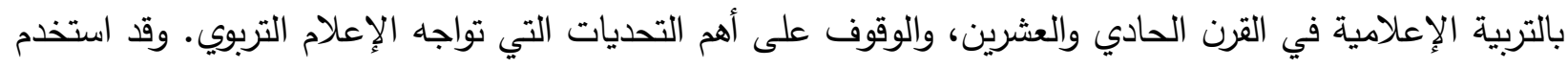

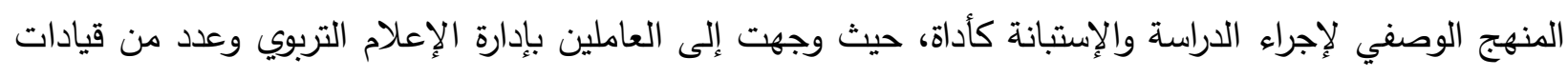

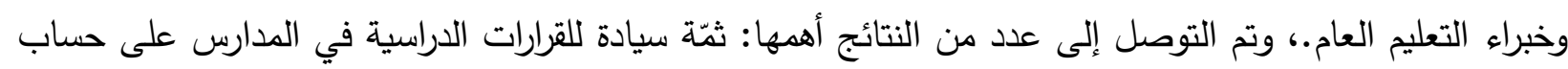

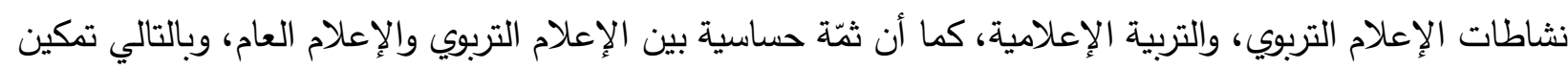

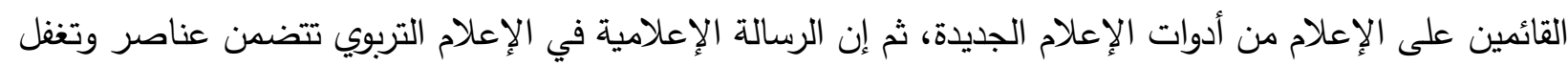
أخرى ولكن سيطرة الدول الكبرى على الإعلام أفرغت غزوًا ثقافئًا كثيفًا. 


\section{مقاربة مع دراستتا}

جاءت دراستتا لتضيف البعد الإيجابي لعملية التعرض لهذه الوسائل من خلال التطرق إلى مهارات التعامل مع الأدوات الجديدة ومدى استغلالها بطريقة إيجابية بعد التعرف على واقع الاستخدام لهذه الوسائل وآثاره الإيجابية والسلبية، بحيث يتم تمكين الثباب خاصة والمجتمع عامة من كيفية التعامل والاستفادة من هذه الوسائل في إثراء العملية التعليمية ولا سيما أن تحديات كورونا فرضت علينا اللجوء إلى هذه الأدوات بشكل أكبر وأكثر .

. 1-4-6- دراسة (4): الإعلام التربوي والتربية الإعلامية الرقمية - مقاربة نسقية مفاهيمية - د.محمد النذير عبدالله ثاني أستاذ مشارك بجامعة حائل - المملكة العربية السعودية دراسة، منشور في مجلة الدراسات الإعلامية المركز الديموقراطي العربي - برلين - ألمانيا - العدد السابع مايو 2019

هدفت الدراسة إلى التعرف على آثار الثورة التكنولوجية وتحولاتها على النشئ ولا سيما الإدمان على الإنترنت، والإقبال على البرامج التلفزيونية والثقافية الأجنبية والتأثر بها أيدولوجيا أو ترويجيا. كما هدفت للتعرف على ماهية وأهمية التربية الإعلامية في مواجهة هذا التحدي. وقد خرجت الدراسة التي استخدمت المنهج الوصفي بنتائج أهمها تأكيد الخبراء أن الثباب ولا سيما الذين لم تتوفر لهم حظوظ كافية من التعليم كانوا على وعيّ ببيئته وملمين بأحداث الساعة من خلال إطلاعه على الوسائل الإعلامية، وقادرين على استخدام أدوات الاتصال في التعبير عن ذواتهم، وأصبحوا مواطنين

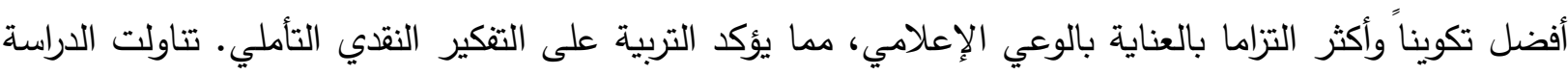

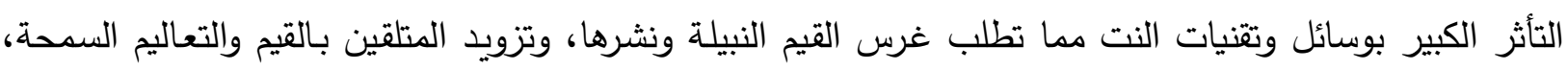
والمثل العليا، وتتمية الإتجاهات السلوكية البناءة، والنهوض بالمستوى التربوي والفكري والحضاري والوجداني للمتلقين.. كما تبين تأثر القيم والثقافات والسلوكيات بالثقافة القادمة جراء التنوع والثقافات الجديدة وإشباع الحاجات والميل للتفاعل مع الأخرين مما تطلب تنمية اتجاهات فكرية تسهم في تعزيز التماسك الاجتماعي وتحقق تكوين الضمير الذي يوجها سلوك الفرد في الحياة، ويعزز الضبط الأجتماعي لاى الفئات الطلابية ونشر الوعي التربوي على مستوى القطاعات التعليمية المختلفة، وعلى مستوى المجتمع بوجه عام، والأسرة بوجه خاص. والاهتمام بالجيل الجديد بوصفهم الثروة

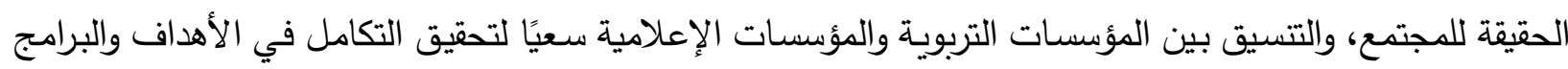
والأنشطة.

مقاربة مع دراستنا : تتاول هذا البحث أهمية وتأثير وسائل الإعلام على أفراد عينة الدراسة وتوصيات الثقافة الفكرية

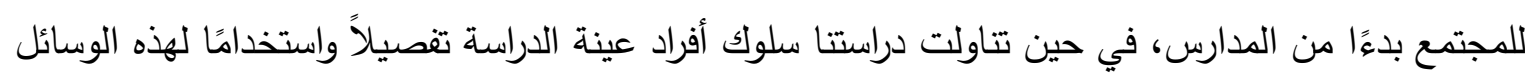
وأولوياتهم في الاختيار ونظرتهم لفلسفة الإعلام التربوي. 


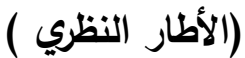

- 2-2 -1-1-1 مفاهيم : التربية الإعلامية الرقمية:

: 1-1- 2

أ- أطلق مؤتمر فينا (1999) الذي أدارته منظمة الأمم المتحدة للعلوم والثقافة ( اليونسكو) تعريفا للتربية الإعلامية لخص مضمونه بما يلي : قدرة الطالب على التعامل مع كل وسائل الإعلام ومضامينها التي تقدمها تقنيات الإعلام

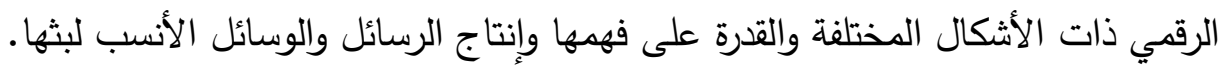
ب- منظمة (اليونسكو) : قدرة الوصول لوسائل الإعلام ومصادر المعلومات الرقمية لمعرفة وفهم مضامينها وتحليلها بإسلوب نقدي , وإبداء ردود الفعل والمشاركة في المضدون المون.

ت- (دليل التربية الإعلامي مدى الحياة , 2016 اليونسكو): المهارات والمعارف التي تمكن الفرد من فهم طبيعة وسائل الاتصال والوسائط التي تتقل المعلومات والمعارف وتخزينها وإعادة التعامل معها بعرضها ونقل وتثكيل ردود

فعل عليها

- 2-1-2

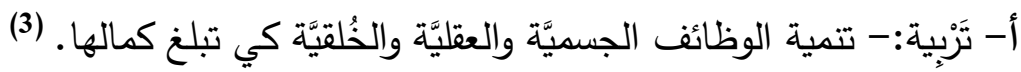

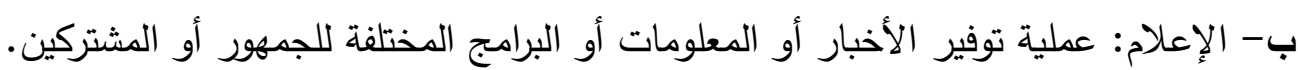
- الإعلام الرقمي (متعدد الوسائط) : مجموعة التقنيات والمنتوجات التي تسمح باستعمال المعلومات في شكل نصوص أو صور ثابتة أو متحرّكة وبطريقة تفاعلية، ويمن أن تكون شبكات مغلقة أو مفتوحة (4) . - التربية المعلوماتية : ممارسة عمليات التعلم والتعليم ومصادر المعلومات كافة والتعامل معها بروح النقد والتحليل والإبداع(5)

- التربية الرقمية : القدرة على استخدام تكنولوجيا الاتصال والمعلومات من أجل الحصول على المعلومات الرقمية وفهما وتقييمها ومن ثم إيصالها. (6) - الملاحة الرقمية : مهارات العثور على المعلومات، وتصنيفها حسب الأولوية المطلوبة، وتقدير صدقية المعلومات

ونوعيتها وأهدافها (7)

2-1-2-1 إجرائيًا : تعريف الفرد في الأردن على وسائل الإعلام وخصائصها وأنواعها وتقنياتها الحديثة ومضامينها بهدف تتشئته وتمكينه من التعامل مع محتواها بوعي وتحليل ونقد وبالتالي المشاركة في إنتاج المادة الإعلامية .

\section{2-2-2 النظرية الإعلامية المعتمدة في الاراسة : المارية}

اعتمد الباحث في دراسته على نظرية الحاجات والإثباعات بوصف الفرد يتوجه للوسيلة التي يرى أنها الأفضل في إثباع حاجاته المعرفية والثقافية ورغباته النفسية والثقافية. ولهذا ركزت أسئلة الدراسة على علاقة أفراد العينة مع الوسائل ئل ئلئل الإعلامية وسلوكياته معها ليبني علاقة إيجابية ما بين مستوى وزمن التعرض والتأثير السلبي والإيجابي. (8) 


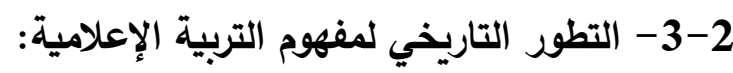

بدأ الأهتمام بالتربية الإعلامية في النصف الثاني من القرن العشرين حينما تتبهت المؤسسات التعليمية بإضافة (تقافة

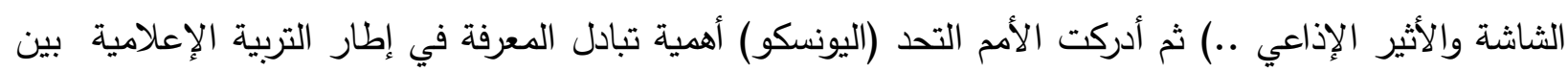

الدول, وتجلى ذلك في توصيات ندوة مدينة جران ولد الألمانية عام 1982 التي تناولت موضوع التربية الإعلامية.

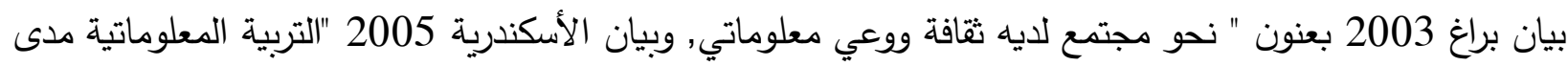

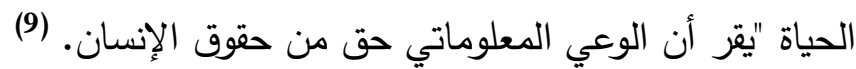
ثم جاء مؤتمر باريس عام 2007 ليؤكد أجندته على أهمية برامج التطبيق وشموليتها لدى المؤسسات التعليمية من التصني

خلال المعلمين وبحوث الطلبة ودخولها المؤسسات المدنية ومتخذي القرار والمجتمع المحيط بالعملية التربوية. (10) ثم جاء إعلان موسكو عام 2013 بأهمية إجراء إصلاحات هيكلية في مناهج التربية لإدخال مفاهيم التربية الإعلامية

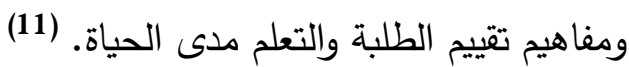
في عام 2015 أدخلت الأمم المتحدة تعديلات على مفاهيم التنمية الألفية واستبدلت المسمّى بالتتمية المستدامة أن سجاما مع التعليم مدى الحياة أكدت على حرية الحصول على المعلومة وحرية الصحافة وضمان حرية التعبير ـ (12) لقد سعت الأمم المتحدة إلى تعميم فكرة المواطنة العالمية أو ما اسمته عالمية المواطنة، وقصدت بذلكية توسيع مفهوم الوطن إلى تجاوز الحدود الجغرافية التي ينتمي اليها إلى المستوى العالمي، من خلال إبراز القواسم المشتركة بين بني البشر . (13) في عام 2016 وفي لاتفيا جاء مؤتمر التربية والإعلام الأوروبي ليؤكد ضرورة تملك المهارات والقدرات الفنية والمعرفية التكنولوجية لوسائل الاتصال ومعرفة مضامينها ليتمكن من ممارسة حقوقه الإنسانية والمعلوماتية بالتعبير والحفاظ على لإعى المهنية وأخلاقيات التعامل مع هذه التكنولوجيا. لقد أصبح الإعلام اليوم بكل أشكاله وأنواعه من ضروريات الحياة، ولا يخلو بيت أو مجتمع من وسيلة من وسائل

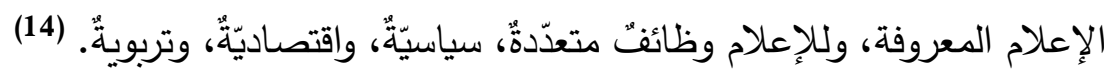

\section{2-2 فلسفة التربية الإعلاميّة الرقميّة.}

تقوم فلسفة التربية الإعلامية على معرفة وفهم العلاقة والبعد التفاعلي ما بين مفاهيم التربية الإعلامية وتطبيقاتها المنهجية بعد دراستها وتحليلها، وبين تطبيقاتها على أرض الواقع ومدى استفادة العناصر الأساسية لمكونات العملية التربوية، وتقوم فلسفة التربية الإعلامية على: أ- مفاهيم التفاعل بين الأفراد والمجتمعات: لتعزيز - حقوق الانسان - الحرية والديمقراطية في المجتمعات النامية - حق الحصول على المعلومة بوصفها حقًا من حقوق الانسان - الانصهار الحضاري - التعايش الديني.- الانصهار 
الثقافي والحضاري - حماية الكرة الأرضية من الأخطار - النزعة نحو الإنسانية والمواطنة العالمية والتثاركية. -

التشريعات الدولية - تتمية وتطوير المجتمعات الانسانية المهشة - تبادل المعرفة والخبرات...الخ (15) لإندانة ب- الثقافة البيئية للاعلام الرقمي.

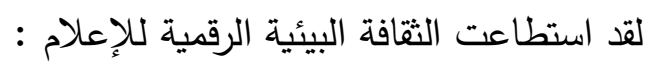
- توسيع قاعدة الثقافة المعرفية الإعلامية وتنوع الأصناف المعرفية وانفتاح المنهجية التفكيرية ووضعها بين يدي أي طالب وأي معلم وأي باحث، مما ساهم في توسيع الأفق الثقافي للفرد. - تعزيز النمط النقدي الأمثل للأفراد من خلال عملية المحاكات والمقارنة والملائمة التي يسعى لأن تكون القاسم المشترك بين مختلف المجتمعات. - تطوير وتعميق ذهنية الطالب بإبداء رأيه والتعبير عن فكره بعيدًا عن السلبية كمتلقي فقط، فالمعلومة تحلل وتقارن وتدخل مجال العصف الذهني الفكري للوصول للنتيجة. وبمثل ما تحمل الثقافات الإعلامية من بيئة وثقافة الإعلام الرقمي من إيجابيات فإن واقع السيطرة على وسائل الإعلام الرقمية والتحكم بمضامين الرسائل المرسلة عبر الفضاء الكوني ومن خلال المجتمعات الافتراضية يثكل تهديدًا صريحًا لواقع المثل والأسس التربوية والاجتماعية والإنسانية للكائن البشري والأسرة والمجتمع , لهذا فإن المؤسسات التربوية والاجتماعية وعلماء النفس والتربية والمجتمع والآباء

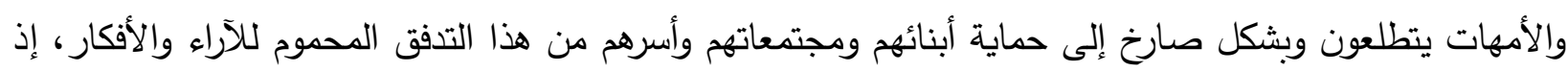
إن بعضها غير سليم وغير متفق مع ثقافتنا، وبناء تتشأة قيمية فكرية واسعة تمكن الطالب من فهم الواقع الإعلام ي التهات وثقافته والسلبيات المرافقة والإيجابيات، ومنهجية الأداء التربوي للمعرفة الإعلامية بثقافتها وبيئتها الرقمية الحديثة.

ت- الإعلام المنهجي في التعليم. يمكن للتربية الإعلامية المدرسية أن تساعد في حلّ مشكلات كبرى مثل مشكلة الأمية الحضارية والأمية التكنولوجية، والأمية السياسية ونحوها. من خلال: - تعويد الطلبة على حب المكتبة المدرسية وحب الكتاب، والرغبة في القراءة، لكونها وسيلة للتوعية والتثقيف والعلاج.

- مساعدة الطلبة على فهم الثقافة المجتمعية والثقافة العالمية، وربط المواد الدراسية بالأحداث والوقائع الحقيقية.

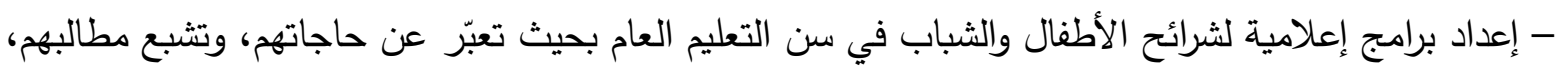
وترقى بأذواقهم وتصحح أفكارهم، وتنظم أمور حياتهم. - مساعدة المعلمين والمعلمات والأباء والأمهات ومن يقع في حكمه على على اكتهاب الثقافة التربوية التي توجه عملهم

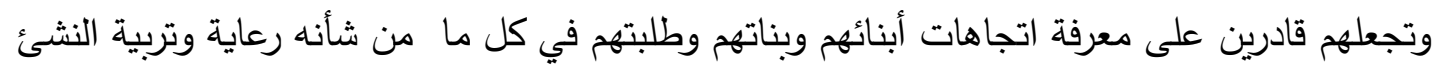
- تعزيز الانتقاء الثقافي الصحيح من البرامج الإعلامية الترفيهية والثقافية، مع العمل على إكساب الطلبة مهارات النقد والتحليل وحل المشكلات.

- تتمية مهارات الطلبة القرائية والكتابية والتحليلية والإدراكية والنقدية، والمساعدة في تتشئتهم اجتماعيًا بشكل سليم. - تحصين الطلبة من المؤثرات الثقافية والحضارية الضارة بالقيم والمعتقدات وبالثقافة المحلية. (17) 


\section{ج- آثار الإعلام على التربية وطرق المعالجة: \\ ج-1 - ج- أثر الإعلام على التربية: (18)}

- لقد ظلت المدرسة المصدر الأول للمعرفة حتى بدايات القرن العشرين، وظل المعلمون هم المصادر الرئيسة لتوزيع المعرفة، وكان الناس قديمًا يعتمدون على المدرسة كمصدر يستمدون منه المعرفة.

ج-2 إيجابيات وسلبيات الإعلام الرقمي

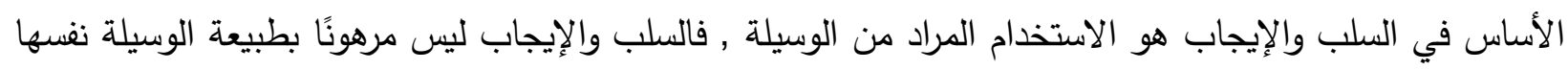

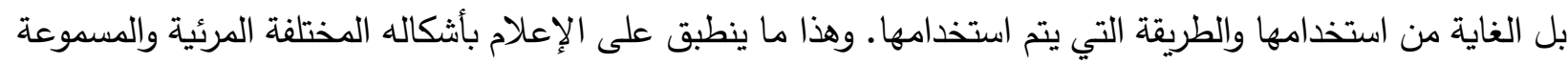
والمكتوبة؛ بل حتى نشرات الإعلان الدعائي يمكن أن تتحول إلى أداة ضارة رغم قصد النفع منها إذا وجهت وجهة الإنة

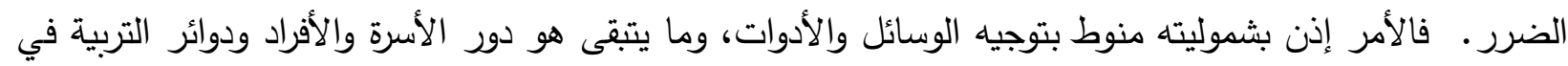

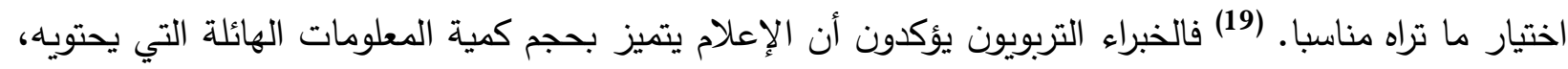
وتجدده. على أن وسائل الإعلام لها دور في توسيع آفاق ومدارك ومعارف الطلبة بوصفها بوابة المعرفة العالمية، وما يعنيه من

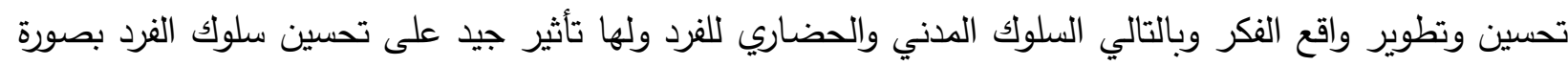

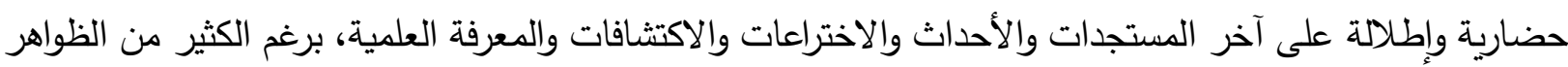

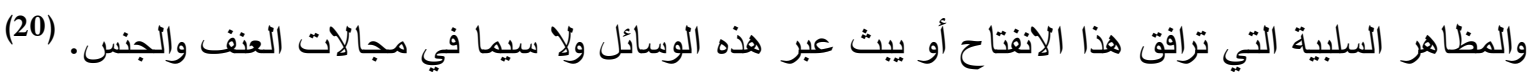

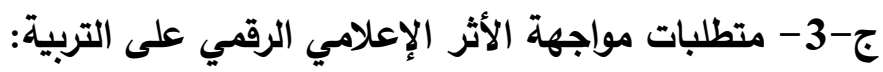

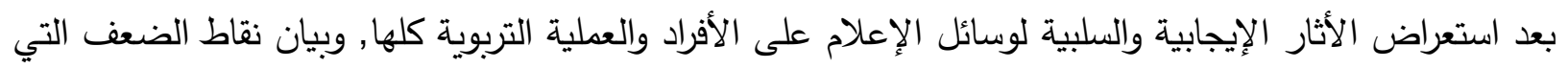

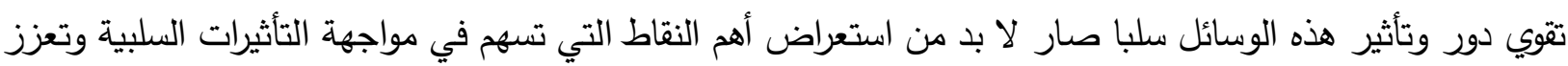
الدور الإيجابي لوسائل الاتصال الرقمي ومنها (21): - تفعيل دور الأسرة، والمدرسة، والمسجد، والمجتمع؛ إذ عليها جميعًا عبء إرشاد الأبناء لكيفية التعامل السليم مع هذه الأدوات.

- غرس مفاهيم الحرية والتعبير عن الذات في داخل الغرف الصفية.

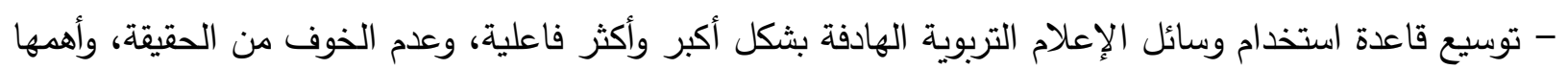

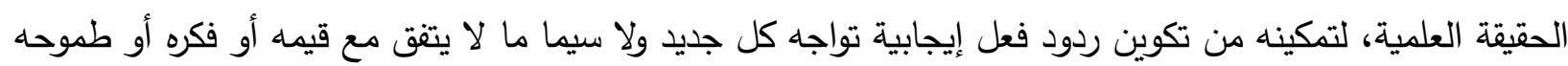

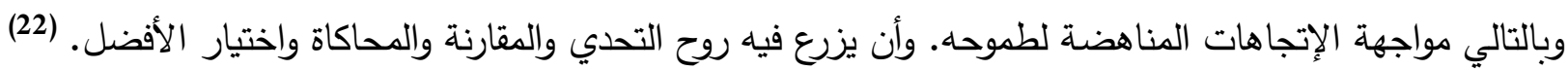

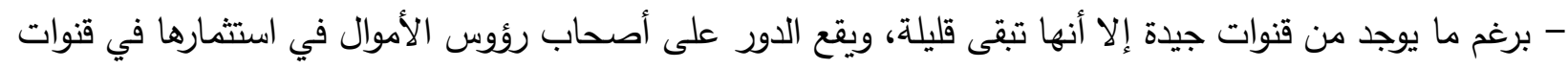

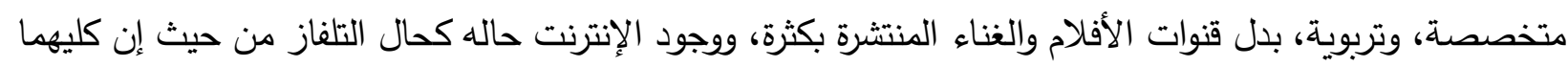
ضرورة، ويطظلّب مراقبة من مؤسسات دولية، ومحلية. وإن نشر الوعي بين الناس لسلبيات الإنسات الإعلام، وغربلة الإعلام 
وتقنينه كفيل بمقاومة التأثير السلبي للإعلام. من خلال الاستمرار بالنصح، والتوجيه للأبناء، وتتمية الرقابة الذاتية

لايهم، وتعميق المفاهيم الدينية والأخلاقية. (23)

علمًا أنه ما يزال بعضهم يضيف فئي مرحلة المقاربة بين التقليدي والملاحة الرقمية بعض البرامج على المناهج بغية

الاستفادة منها (فلندا). (24)

- تشير بعض الأبحاث إلى أنه لا علاقة إيجابية بين مستوى استخدام تكنولوجيا الإنترنت مثلاً (الحاسوب) لاى المتعلمين والتقدم في مساق الرياضيات، أو الإرتقاء بمستوى القراءة والكتابة , إلا أنه يمكن القول بأن هذه التكنولوجيا

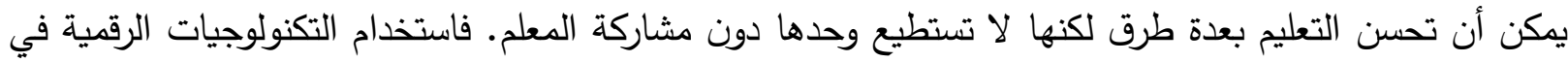

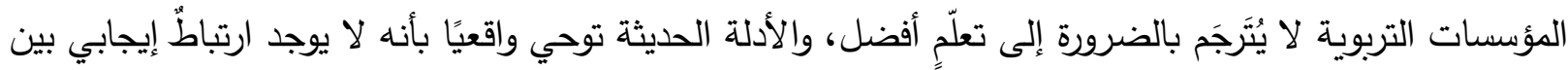

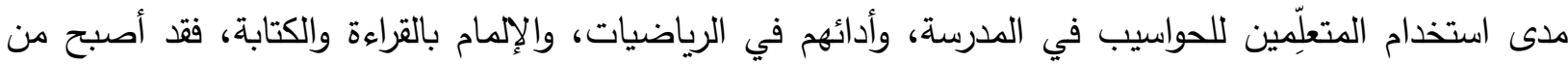

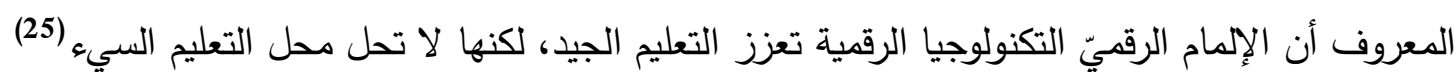
2-2 - التربية الإعلامية الرقمية في الأردن. حال الثباب في الأردن حال الثباب في العالم يجدون من وسائل التواصل الاجتماعي أو الرقمي فرصة للتعبير عن الذات لا سيما أن بعض الوسائل تخفي الهوية وتمنح الفرد فرصة القول والتعبير فتوفّر لله ما لم توفره مراحل وطرق التردي التعليم والتتشئة التي تفرض رقابة كبيرة. وهنا نجد أن الثباب كانوا وما زالوا عرضة وهدفًا لأصحاب الأجندات السياسية والأيدلوجية وقد أثار استطلاع (إتجاهات الشباب ,2015. دراسة رمركز الدراسات الأستراتيجية الجامعة الأردنية ).إلى أن 8\% من الشباب قريبون من المنظمات الدولية. غير أنها تراجعت بدراسات لاحقة وبشكل ملحوظ. إن التربية الإعلامية وتمكين الثباب من مهارات التعامل مع وسائل الإعلام الرقمي وفهم خصائصها ومضامينها تراهيا

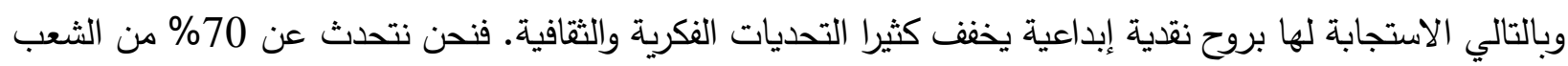
الأردني هم من الثباب أي من أعمار 15-64 سنة وبمعدل 29 سنة وهم الأكثر عرضةً للتعامل مع النت وتقنيات الإعلام الرقمي، في الوقت الذي تبلغ فيه نسبة السكان الذين يستخدمون ويتعرضون للإنترنت في الشرق الأوسط يزيد

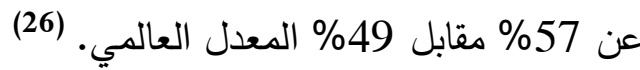
قاد قام محمد الراجي، وهو باحث في مركز الجزيرة للدراسات، بدراسة حول الإعلام الرقمي والمناخات المعززة والمعطلة

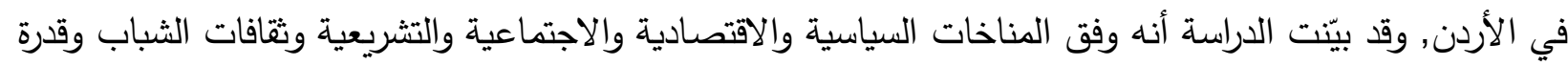

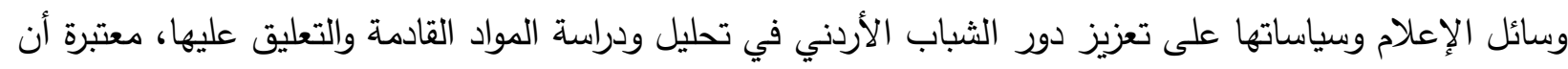

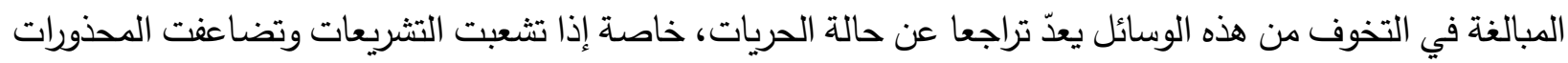
مما يخلق إرباكا وفوضى وتثعبًا في مناحي عزل الأفراد عن المجتمع العالمي. ويعدّ مطلع القرن العشرين البداية في هي نثأة الصحافة الإكترونية في العالم العربي ومنها الأردن خاصة وتحديدًا في بدايات 2005 و و2007 (وكالة سرايا الإخباريّة )، ثم بدأت المنافسات كسباق محموم إلى أن بلغ عددها على ما يزيد عن 1000 موقع، فبرزت كصناعة

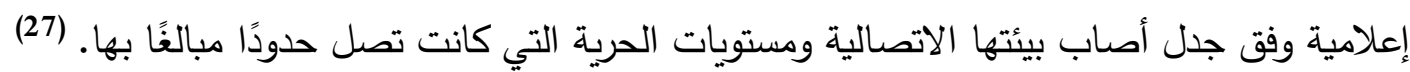


إن التضييق على حرية التعبير في المواقع الإكترونية (الحريات الإكترونية/الإنترنت) دفع بمنظمة فريدوم هاوس في تقريرها السنوي الخاص بمؤشر حرية الإنترنت في العالم لعام 2017، إلى تصنيف كل من مصر والسودان والسعودية والبحرين والإمارات وسوريا في خانة "دول غير حرة"، ودولًا أخرى مثل المغرب وتونس وليبيا والأردن ولبنان في خانة "دول حرة جزئيًا، وهو التصنيف نفسه الذي احتلته هذه الدول في مؤشر حرية الإنترنت لمؤسسة فريدوم هاوس خلال العام 2016، (وهو يقيس مستوى هذه الدول فيما يخص حرية الإنترنت، وحرية وسائل الإعلام الرقمي، وحرية وسهولة الوصول إلى المعلومات عبر الأجهزة والمنصات الرقمية المختلفة وفي تفاعلها مع البيئة الإعلامية، غير أن تجربة الصحافة الإكترونيّة في الأردن تميزت بالخصائص الآتية: - ساهم الإعلام الرقمي المعرفي بمساعدة الناس الأضعف فرصًا على التعلم، ممن لا تسمح لهم الظروف ذلك كالمسجونين والمرضى في المستشفايات والمناطق النائية، وفتح مجال التعليم للموظفين الملتزمين بدوامهم أن يتعلموا

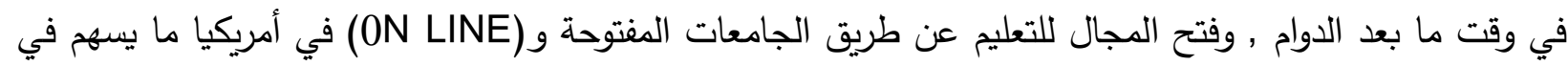

الدمج الاجتماعي، على أن تلك الأبحاث بينت ضرورة وجود استعداد للعلم. (28) - أنتج العمل الصحفي الإلكتروني في الأردن مفهومًا خاصًّا أو مفهومًا جديدًا لحرية الصحافة الإلكترونية عبر تفاعله مع محيطه السياسي. - أنتج العمل الصحفي الإكتروني كُتابًا فاعلين جددًا من خارج الجسم الصحفي التقليدي أسهموا في بلورة المفهوم الجديد لحرية الصحافة الإلكترونية وصياغة مرتكزاته. - تجسيد تطورات المشهد السياسي والاجتماعي الذي وُسمِتَ إحدى محطاته بالحراكَ الشعبي ومطالبته بالإصلاح وذلك عام 2011. - وجود علاقة تبادلية بين مظاهر البيئة الإعلامية للصحافة الإلكترونية والسياق السياسي العام؛ حيث ينعكس هذا التفاعلُ. 2-4-2-2 الصحافة الإكترونية واتجاهاتها في الأردن أ-2-2-3- مراحل حالة الحرية الصحفية الإكترونية. أ- حالة حرية الصحافة الإكترونية قبل التثريع (2006- 2011)، قبل أي قانون لتنظيم الإعلام الإلكتروني . ب- حالة حرية الصحافة الإلكترونية بعد التشريع (2012- 2015). ت - حالة حرية الصحافة الإلكترونية (2015-2016).

أ-حالة حرية الصحافة الإكترونية قبل التشريع (2006-2011) : امتزجت حرية الصحافة الإلكترونية في هذه المرحلة بمظاهر مختلفة، حيث خضعت خلال هذه المرحلة لمقتضيات قانون المطبوعات والنشر رقم 8 لسنة 1998 قبل أن يُعَدَّل في العام 2012(29) ويستوعب الصحافة الإكترونية المادة 49 التي الزمت المطبوعات الإكترونية التي تتشر الأخبار والتحقيقات والمقالات والتعليقات بالتسجيل والترخيص، وتطبق عليها جميع التشريعات النافذة ذات العلاقة بالمطبوعة الصحفية وقد امتازت هذه المرحلة بما يلي: (30) 
- سقف مفتوح من الحرية في التعبير : إذ بدت مظاهر مختلفة لحرية الصحافة في سياق الفراغ القانوني، الذي واكب مرحلة التأسيس وتطور النشاط الصحفي الإلكتروني خلال الأعوام الستة الأولى، والتي مثلت حالة خاصة بحرية الصحافة لهذا القطاع الإعلامي و"ارتفاع منسوب أو مستوى حرية الصحافة الإكترونية " عمومًا في هذه الفترة، إذ إذئه ظهر فيها ما يأتي: > تنبهت الدولة لخطورة المواقع الإخباريّة الإككترونية، وسقوف الحرية الإعلامية المفتوحة ووجود إراده حقيقية في توسيع قاعدة حرية التعبير في إطار مسيرة الدولة في الإصلاح السياسي. > وجود شغف ونهم لدى الإعلاميين والصحفيين في التعبير عن هموم ومشاكل الوطن والمواطن. > شكلت الصحف الإلكترونية حالة من الحرية في انتقاد النواب والحكومة والقطاعات الأخرى والتأثير في الرأي العام . > تحجيم الصحف الأسبوعية التي كانت تمثل سقفا عاليا من الحرية من عام 1992 وفرض قواعد تشريعية صعبة حدت من سقف الحرية فيها.. وتجاوز الحريات لسقف المحرمات والوصول لسقوف وهمية خرقت كل التابوهات. > أصبحت التعليقات تحظى بأهمية اتصالية بالغة بوصفها مؤشرًا محددًا لحجم أن تثار الصحيفة الإكترونية وتأثيرها

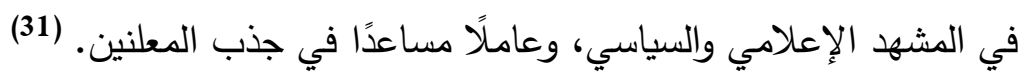
- فوضى سقف الحريات (الوهمي ) و تجاوز الخطوط الحمراء : لقد ساهم واقع الحريات العالي وتجاوزه السقوف الحمراء وكسرها من الإعلاميين في الصحف الإكترونية والمعلّقين والمواطنين الإعلاميين, والجراءة العالية في النقد والوصول إلى الحديث في بنية المحذورات كالجيش والأجهزة الأمنية ومؤسسة العرش, لظهور عدد من المميزات لهذه المرحلة، التي تمثّلت بما يأتي:

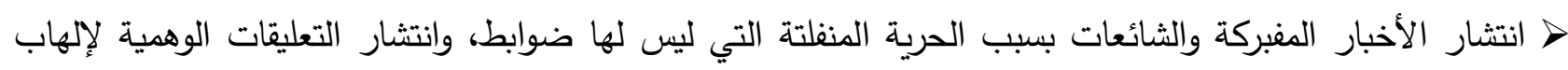
واستثارة حماس المستخدمين/المعلقين للاشتباك، وإصدار الأحكام القاسية بدل التتوير وإطلاع الرأي العام على لهیى المعلومات والحقائق، كما تمّ توظيف الصحافة الإلكترونية لمحاكمة الأفراد والتجاوز على حقوق الآخرين والاغتيال الرمزي والمعنوي للشخصية، والتشويش الفكري والثقافي الذي تعرض له الجمهور بسبب إغراق المشهد الإعلامي بالصحف والمواقع الإخباريّة الإلكتروني، حيث اختلط الحابل بالنابل، بما انعكس سلبًا على جودة المنتج الإعلامي.

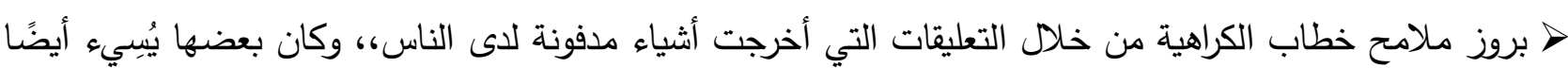

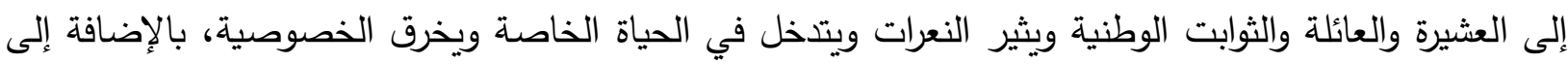

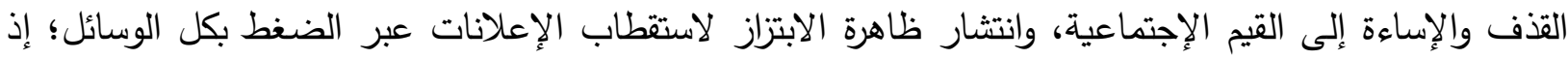
أصبحت المواقع الإخباريّة منصات لكسب المال. وظهور ظاهرة تمويل بعض المواقع حيث دخلت فيها عوامل اتصالية ومصالح اقتصادية وسياسية، وهو ما يؤثرّ في استقلالية المواقع الإخباريّة الإكتروني ومن ثم دورها وإطارها الوظيفي وموقعها في المجال العام كراو للثقافة السياسية وأداة للخطاب، لذلك يصبح متغير التمويل محددًا أساسيًّ لطبيعة البيئة الإعلامية الإلكتروني بكل مكوناتها وعناصرها. (32)

\section{ب- حالة حربة الصحافة الإلكترونية بعد التشريع (2012- 2015) -}

اكتسبت الصحافة الإكترونية زخمًا كبيرًا وحضورًا قويًا في سياق الحراك الثعبي، مما جعل بعض التجارب الصحفية تعيش حالة انغمارٍ وتماهٍ مع تطورات هذا الحراك ومساراته، وقد أسهم النشاط الصحفي الإكتروني عمومًا - قبل مرحلة التشريع- في ضخّ جرعات من الجراءة وسَّعت مساحات حرية الرأي والتعبير وأدت إلى تكسير الخطوط الحمراء 
والتابوهات التي لم تستطع الصحافة التقليدية والإعلام الرسمي الاقتراب منها. بما تحمل تلك الفوضى وذاك الانفلات لحرية الصحافة الإكترونية من مظاهر سلبية، أضرت أولاً بالنشاط الصحفي الإلكتروني، وثانيًا: بالمجتمع ومنظومته القيمية والثقافية، وأمام هذه النتائج دفعت السلطة/الحكومة إلى العمل على تتظيم الحقل الصحفي الإلكتروني وقَوْنَنَةٍ نشاطه عبر مجموعة من التشريعات التي كان أبرزها :

قانون المطبوعات والنشر المُعدَّل رقم (32) لسنة 2012، الذي استوعب الصحافة الإلكترونية لأول مرة وألزمها بالتسجيل والترخيص، حسب المادة (49) التي تضمنت : إلزام الصحف الإكترونية بالتسجيل والترخيص بقرار من المدير ، وعلى مالك المطبوعة الإلكترونية توفيق أوضاعه وفق أحكام هذا القانون خلال مدة لا تزيد على تسعين يوما من تاريخ تبليخه قرار المدير بذلك.

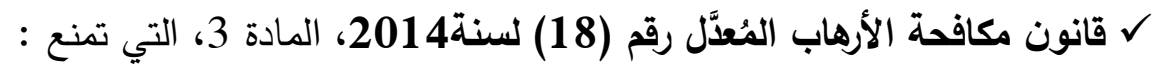
استخدام نظام المعلومات أو الثبكة المعلوماتية أو أي وسيلة نشر أو إعلام أو إنشاء موقع إلكتروني لتسهيل القيام بأعمال إرهابية او دعم لجماعة أو تتظيم أو جمعية تقوم بأعمال إرهابية أو الترويج لافكارها. ل قانون منع الجرائم الإكتروني رقم (27) لسنة 2015 (بنسختيه المعدَّلتين 2017 و 2018)، التي تمنع: إساءة استخدام الوسائل الذي نجم عنه انتشار ظاهرة الجرائم الإككترونية سواء ما يمس الوحدة الوطنية إضافة إلى الى الجرائم الماسة بالأشخاص مثل جريمة الابتزاز والجرائم الواقعة على الأموال كجرائم الاحتيال الإلكتروني. قانون العقوبات: قانون العقوبات رقم 16/ 1960 وجميع تعديلاته، المادة (122 ) التي تعاقب كل من ارتكب دون مبرر تحقير دولة أجنبية أو جيشها أو علمها أو شعارها الوطني علانية أو زعيمها..إلخ. المادة (150 ) التي تعاقب صاحب كل كل كتابة، أو خطاب أو عمل يقصد منه أو ينتج عنه إثارة النعرات المذهبية أو العنصرية أو الحضً على النزاع بين الطوائف ومختلف عناصر الأمة يعاقب..إلخ. ت- حالة الصحافة الإكترونية بعد 2015 : ارتقع مؤشر الرقابة الذاتية بنسبة 91.3\%، إذ "حاصرت الحكومة الإعلام ولا سيما الإعلام الإكتروني، وفرضت قيودًا على الإعلام الإلكتروني والتعليقات التي ينتجها المواطنون تعقيبًا

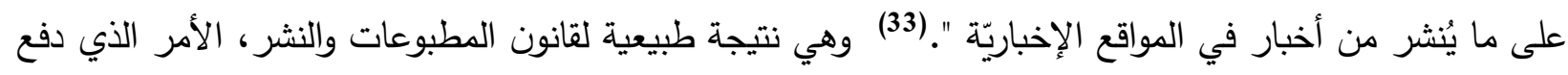

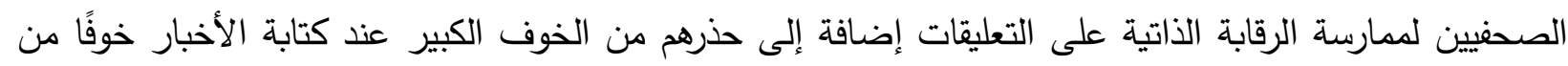
الملاحقة القانونية. في هذا السياق العام الذي يُوَّبّرِ المشهد الإعلامي، صنَّفت منظمة فريدوم هاوس في تقريرها السنوي

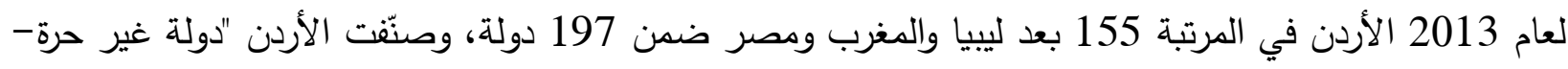

وقد ازدادت القضايا التي تُزْفَع ضد الأشخاص في قضايا النشر خلال عامي 2016 و2017،، وملاحقة الناس بسبب كتاباتهم وتدويناتهم على الفيسبوك، وهو أحد ملامح هذه المرحلة، كما تراجع الأردن في مؤشر حرية الصحافة في تقرير لثبكة مراسلون بلا حدود عام 2014 بمقدار سبع درجات عن العام 2013 و وكانت سيفا مسلطًا على أقلام

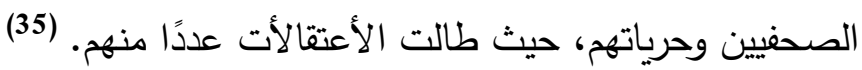


2-4-4- الأطار التشريعي والتظيم القانوني للصحافة الإكترونية ـ في غضون سبعة أعوام والمشهد الإعلامي للصحافة الإكترونية يخلو من التشريعات الضابطة، والتي اتسمت حسب مناخ الحريات الإعلامية الذي وصل سقفه السماء كما صرح به الملك عبدالله الثاني ملك الممكلة الأردنية الهاشمية. وتضاعفت أعداد المواقع الإكترونية في الإدي الأردن حتى تجاوز الألف. و ومثلت هذه المواقع حالة متميزة من التعبير العام والنقدي والمطالبة بالإصلاح السياسي والاقتصادي والاجتماعي , ومحاربة الفساد واتهام عدد من الجهات , ومهاجمة أداء الحكومة وانتقاد مجلس الأمة. وقد ولد

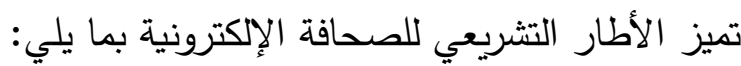

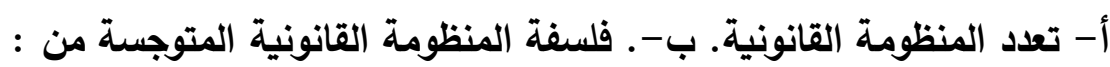
- الروتين العام الذي تعوده رجل الدولة وموظفوها. - الحالة الأمنية وتأثيرها في موظف الدولة ولان سيما الذين هم من الدرجة الأولى. - عدم استيعاب أهمية ودور الإعلام ووسائل التواصل ولا سيما الرقمية من النهوض في في الدولة وإحداث التنمية الثاملة. وقد ساهمت هذه العوامل بفرض القيود الآتية:- قيود قانونية (التعاريف الفضفاضة).- القيود الجزائية وهاجس الزج بالسجن - القيود الأمنية: تتحكم الرؤية الأمنية في فلسفة القوانين خوفًا من الحرية.- القيود المهنية: التي تتطلب قدرة الصحفي من الوصول للمعلومة. وقيود القوانين غير المكتوبة. فنحن جميعا نتطلع إلى ضوابط الحرية وليس إلى موانعها أو تقييدها، إذ ضمن الدستور حرية التعبير عن الرأي ؛ لأنها حق من الحقوق التي لا تحتمل الحوار والجدال، لكنها حق إقى مشروط بالمسؤولية وحقوق الأخرين.. فالمانع والقيد يعني بالمطلق الحد من الحرية , لكن الضابط يرسم الأطار والحدود بقصد التطوير، وسلامة المجتمع وأمنه والمصلحة العليا للدولة وصون حق الفرد وحرمته والأسرة والمجتمع وحقه الأمني والاجتماعي

\section{2-4-5 - 2 مفاهيم التربية الإعلامية:}

تقوم الرؤية الأردنية للتربية الإعلامية والمعلوماتية على تطوير المفاهيم الإعلامية وترسيخها لدى أفراد المجتمع الأردني بهدف تصويب مفاهيم الممارسات الإعلامية وفق معايير الحرية المسؤولة وبناء المجتمع المسؤول بل الفرد

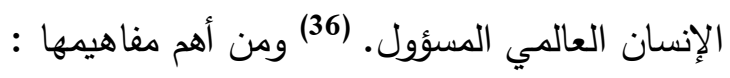

أ- التربية : وظيفة هذا العلم البحث في أسس التتمية البشرية وعواملها وأهدافها الكبرى، وتقوم على التتمية والتَهْذِيبُ وَالتَعْليُُ وَالتتشئة الثاملة والتثقيف والتغذية الفكرية, وتعزيز قيم الأخلاق والعقل. وتكوين المواطن الصالح, أي تكوين الثخص الذي يمتثل الأوامر والنواهي والقوانين في المجتمع بمحض إرادته لإحداث النمو المتوازن الجسدي والعقلي.. وبناء مجتمعنا الذي يحتاج إلى تعزيز قيم وثوابت ومعايير اخلاقية ومهنية قائمة على:

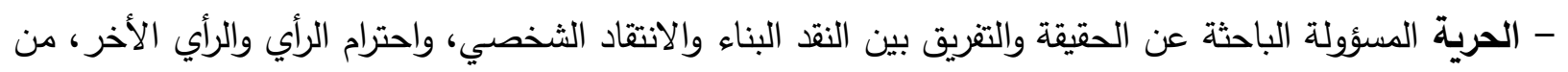

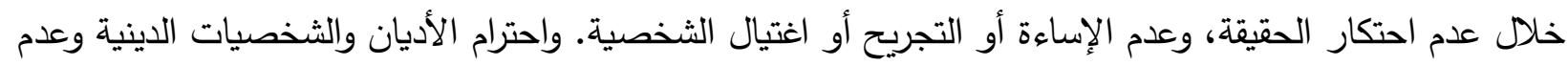
الإساءة للاقليات. أو أمن المجتمع وسلامته ووحتته، والتعامل الإعلامي القائم على المهنية وأخلاقياتها، وخلق تفاعل

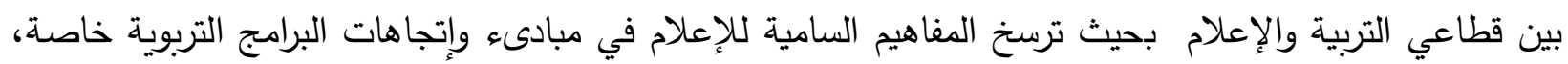
كجزء من مناهج الطلبة وللمراحل كافة المدرسية والجامعية (37) . 


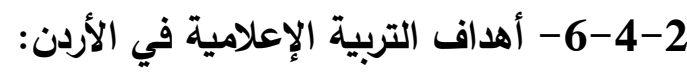

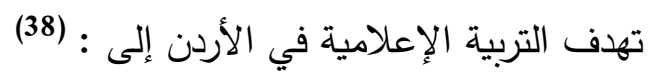

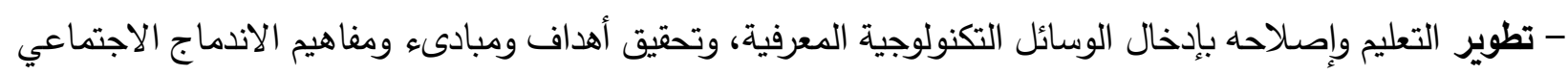

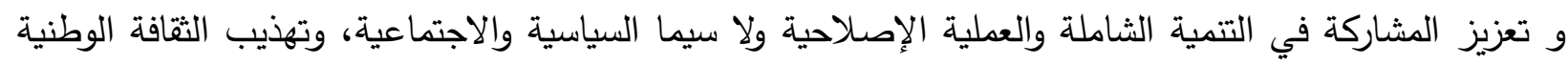

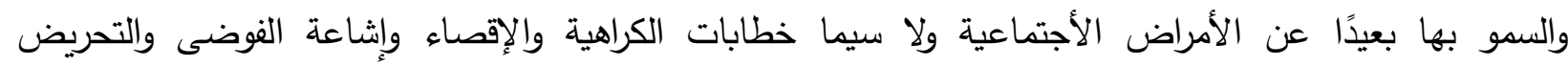

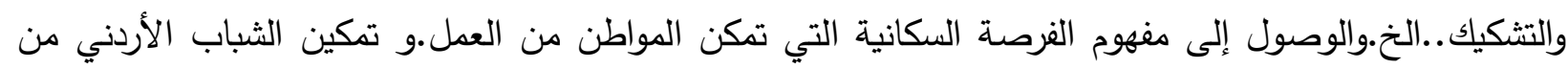

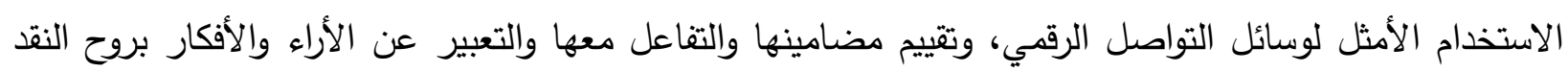

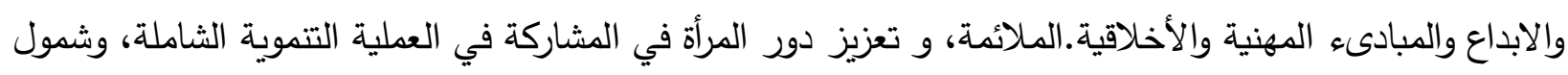

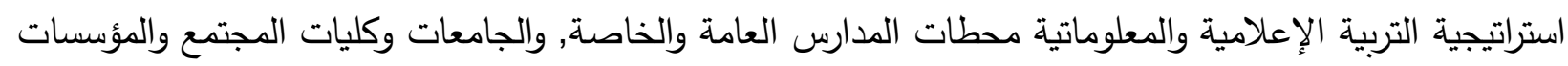
الأرشادية والتوجيهية والإعلامية.

\section{2-4- 7- الاستهلاك الإعلامي الرقمي في الأردن.}

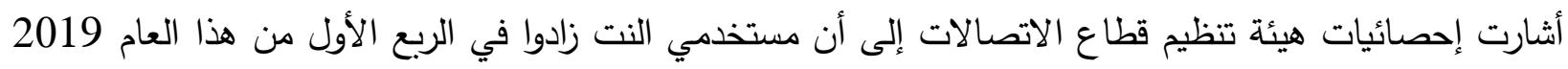

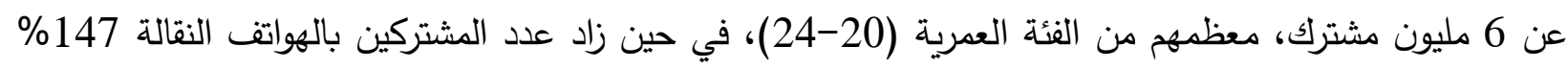

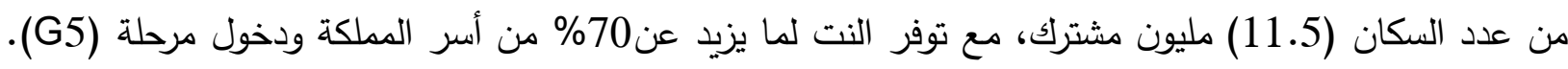

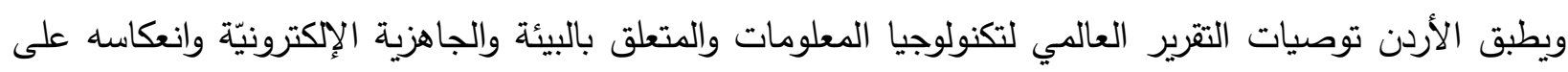

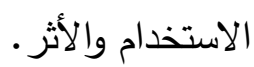

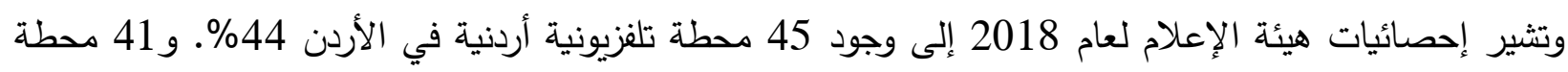

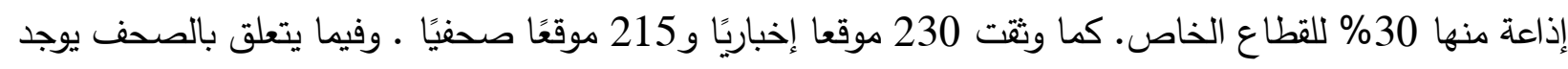

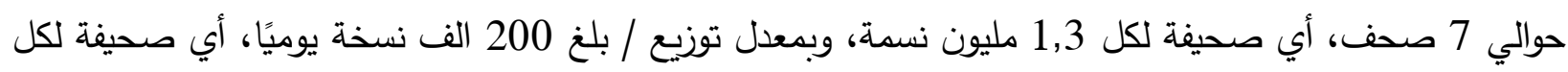
46 شخص حسب إحصائات 2018 لشركة ابسوس للأبحاث والدراسات 2012 -2013 لوند

\section{2-8-8- 2-8 التثريعات الإعلامية التربوية:}

لقد أُجريت الكثير من التعديلات على التشريعات الإعلامية والتربوية لتتلاءم مع التطورات الحاصلة على واقع التواصل

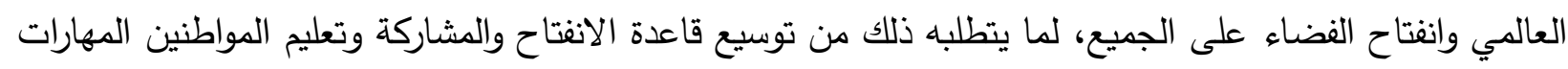

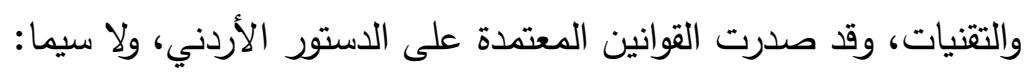

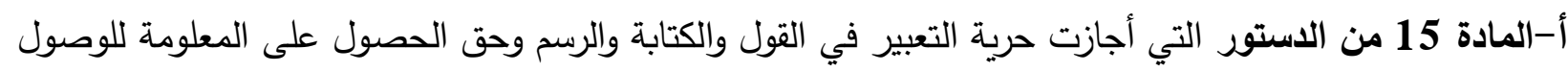

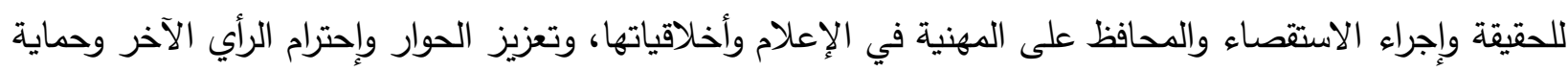
المجتمع والبعد عن الفوضى والتحريض والإساءة, والقدرة على الاستجابة الإيجابية وبيان الحقائق. 
ب- قانون وزارة التربية والتعليم رقم 3 لسنة 1994، حيث نصت المادة 4 الفقرة (ه) على تمكين الطالب من الانفتاح على الثقافات الإنسانية كافة, فركزت المادة في فقرتيها:(ح, ط) على تمكين الطالب من التعرف على مهارات الانفتاح

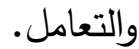

ت - قانون التعليم العالي والبحث العلمي رقم 23 لسنة 2009 حيث أشارت الفقرات (ج د هـ ي) إلى أهمية الحفاظ على التراث الوطنية واحترام الهوية الوطنية والثقافة الوطنية العربية والعالمية، وتعزيز مهارات الإبداع والابتكار والتفوق، إضافة لتوفير البيئة البحثية النقدية وإجراء الدراسات والأبحاث والوصول للآراء والأفكار العامة والدقيقة للمواطينين. ث - قانون حق العصول على المعلومات. قانون رقم 47 لعام 2007، وفق ما كان قد صدر عن الأمم المتحدة ، وتحديدًا قرار رقم 59 الذي طالب بحق المواطن بالحصول على المعلومة من الجهات العامة, وعلى هذه المؤسسات العامة تأمين هذه المعلومات لطالبها. وكانت الأردن الدولة العربية الثانية التي أقرت هذا القانون بعد لبنان، وقد أُقرّ القانون وأصبح نافذ المفعول عام 2007.

3

1-3 - المنهج العلمي والخصائص الايمغرافية لعينة الاراسة:

: 1-3 - 1-3 عينة الاراسة

توزعت الخصائص الديمغرافية لعينة الدراسة حسب المستوى المهني، والمستوى التعليمي والنوع الاجتماعي (الجندر) حيث تمت الدراسة على المجتمع الأردني كمجتمع للدراسة مثلتها عينة طبقية عشوائية شملت 600 فرد، ومن مختلف المستويات العلمية والمهنية والجندر، حيث استجاب (559) مستجوبًا، ولم يجب (41) وبنسبة (93\%). موزعة كما

\begin{tabular}{|c|c|c|}
\hline النسبة & العدد & نوع الجندر \\
\hline$\% 54$ & 330 & ذكور \\
\hline$\% 46$ & 229 & إناث \\
\hline
\end{tabular}

\begin{tabular}{|c|c|c|}
\hline النسبة & العدد & المهنة \\
\hline$\% 22$ & 120 & مدارس \\
\hline$\% 14$ & 78 & جامعات \\
\hline
\end{tabular}




\begin{tabular}{|c|c|c|}
\hline$\% 8$ & 38 & جامعات \\
\hline$\% 9$ & 52 & مدارس \\
\hline$\% 13$ & 74 & موظفون \\
\hline$\% 22$ & 100 & متقاعدون \\
\hline$\% 15.3$ & 86 & إعلاميون \\
\hline
\end{tabular}

\begin{tabular}{|c|c|c|}
\hline$\% 23$ & 125 & ما دون التوجيهي \\
\hline$\% 25$ & 143 & الدبلوم \\
\hline$\% 42$ & 237 & البكالوريوس \\
\hline$\% 3$ & 18 & الماجستير \\
\hline$\% 7$ & 36 & الدكتوراه \\
\hline
\end{tabular}

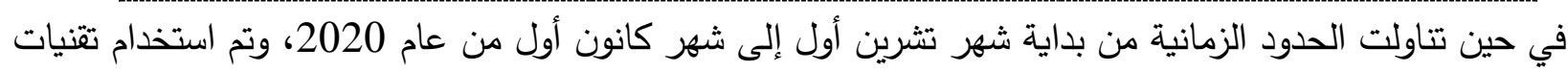

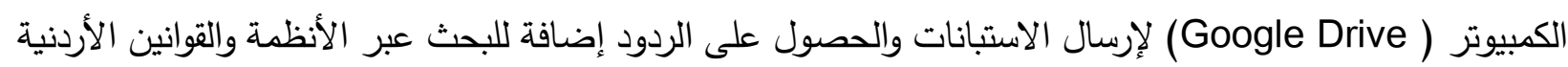
من خلال منصات المؤسسات الوطنية.

\section{2-1-3-2-1 المنهج العلمي والطرق الإحصائية المتبعة:}

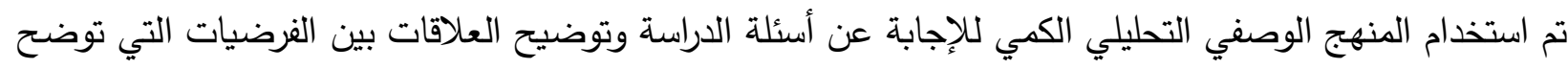

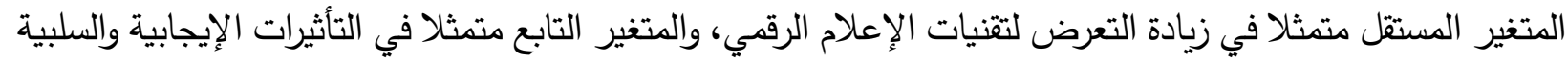

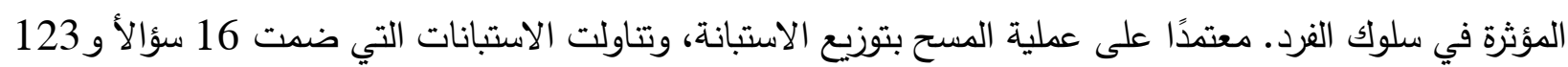

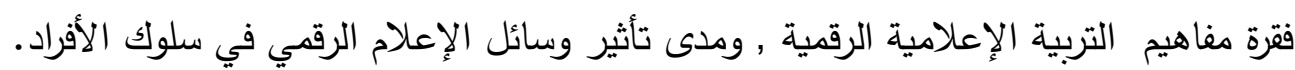

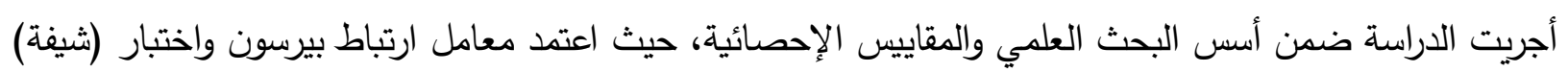

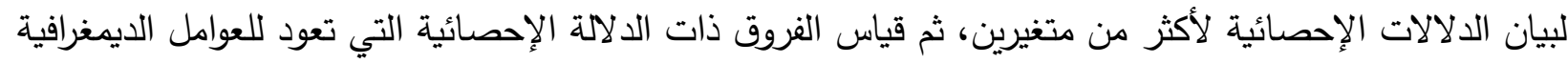
لأفراد عينة الدراسة. حيث تم استخدامه في معظم فرضيات الدراسة للإجابة على مستويات هذه المتغيرات، ومقياس

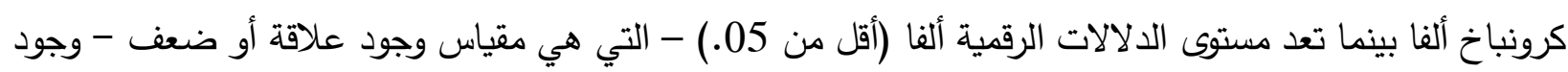
العلاقة بين مستويات عينة الدراسة اضافة لطريقة T.test. واعتمد الباحث سلم ليكرت كمعيار إحصائي لتصحيح

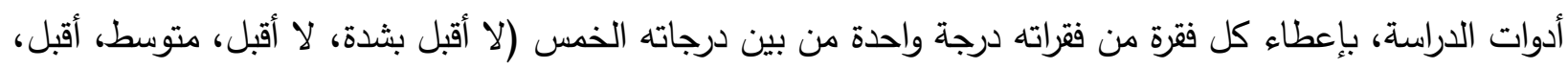

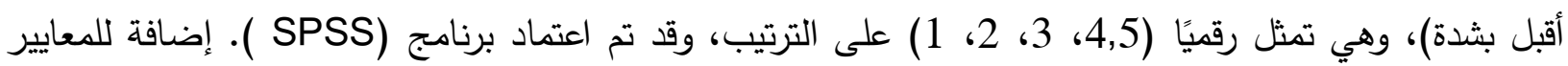




\section{الإحصائية الحسابية الأخرى كمقاييس التشتت المركزية وغيرها).}

3-2-3- نتائج الاراسة : بينت نتائج الدراسة بعد تحليل ودراسة اختيارات الأفراد وعددها ونسبها ومتوسطاتها الحسابية والانحراف المعياري، و الوسائل الإحصائية والحسابية كما يلي : (ملاحظة سيتم وضع جداول حول توزيع البيانات

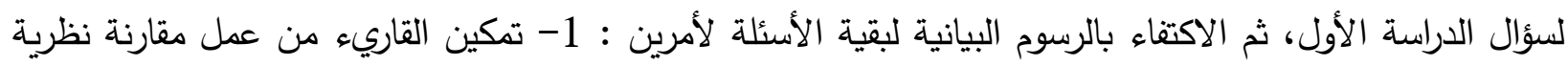
لتوزيع التكرارات بين الفقرات ومستويات تركيز عينة الدراسة حسب مقياس ليكرت الظاهرة أكثر في الرسوم البيانية. 2اختصار عدد الصفحات لما ينسجم مع متطلبات النشر ما دام النتيجة موضحة بالرسم البياني).

أولا : سؤال الدراسة الأول والمتعلق: هل يزيد التعرض لوسائل الإعلام الرقمي من ثأثيرها في الفرد، وبمستوى استخدام

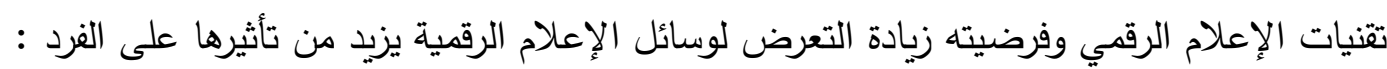

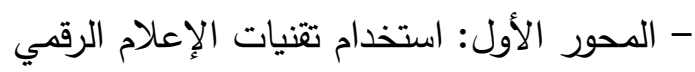
يتبيّن من خلال النظر إلى الجدول والرسم البياني رقم 1 التوزيع التكراري والنسب المئوية والمتوسطات الحسابية والانحرافات المعيارية لمدى اهتمام عينة الدراسة باستخدام الإعلام الرقمي أن المتوسطات الحسابية لفقرة خلق المجتمع المعرفي لاى أبناء الكرة الأرضية حصلت على أعلى متوسط حسابي), وبمستوى متوسط وبانحراف معياري مقداره 887,. ، بينما حصلت الفقرة ( مساعدة الدول النامية للنهوض والتطور والتتمية) والفقرة (الحد من العزلة المعرفية بهدف تثقيفنا لمواجهة المستقبل) على أدنى متوسط حسابي مقداره (2) وبمستوى متوسط أيضا ـ مما يشير إلى أن ثمّة ارتباطا واضحا بين الفقرات وبعلاقة إيجابية طردية تحقق فرضية السؤال، لا سيما وأن مستوى الدلالة الفا كان (>5, ) وللمستويات كافة, وهذا يتماشى مع نظرية الحاجات والإشباعات التي تعكس مدى تعلق الناس بمضامين الوسائل الإعلامية؛ لإثباغ رغباتهم وحاجاتهم للمعرفة وبالتالي التوجه للاعلام والوسيلة المختارة

جدول رقم ( 1) مجموع التكرارات الإحصائية لراي العينة على سؤال لماذا نستخدم الإعلام الرقمي.

\begin{tabular}{|c|c|c|c|c|}
\hline | الإنحرافالمعياري & | المتوسط لحسابي & 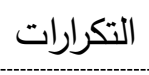 & | الفقرة & اقم الفقرة \\
\hline., 887 & 2.99 & 97 & خلق المجتمع المعرفي لدى أبناء الكرة & 1 \\
\hline .831 & 2.7 & 85 & $\begin{array}{r}\text { الأفراد ولا سهارات النقد والتحليل والتدقيق لاى } \\
\text { المجتمعات النامية }\end{array}$ & 2 \\
\hline .767 & 2.44 & 72 & |لانسيل قواسم مشتركة بين المجتمعات & 3 \\
\hline .752 & 2.3 & 69 & : توسيع قاعدة الرأي العام العالمي & 44 \\
\hline .742 & 2.1 & 62 & | التبادل الثقافي بين المجتمعات & 5 \\
\hline .741 & 2.1 & 61 & تجسير فوهة المعرفة بين بني البشر & 6 \\
\hline .732 & 2 & 55 & والتنمية & 7 \\
\hline
\end{tabular}


مجلــة جامعة الزيتونة الأردنيّة للدراســات الإنسـانيّة والاجتمـــيّة، المجلد(2)، الإصدار(2)،2021

\begin{tabular}{|r|r|r|r|r|}
\hline 731 & 2 & 54 & 8 & \\
& & & & \\
& & 522 & & \\
\hline
\end{tabular}

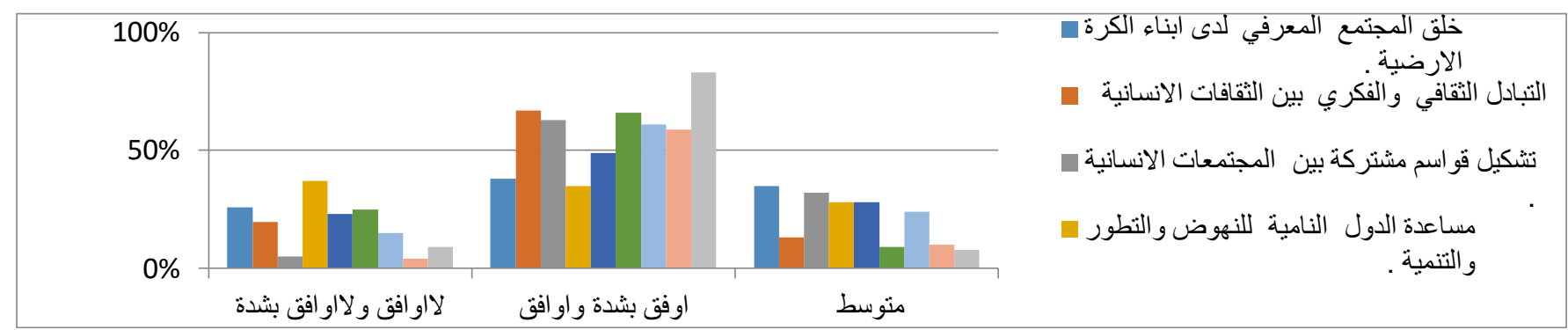

رسم بياني رقم ( 1) مجموع التكرارات الإحصائية لراي العينة على سؤال لماذا نستخدم الإعلام الرقمي.

لقد حصلت فقرة (خلق مهارات النقد والتحليل والتدقيق لاى الأفراد ولا سيما المجتمعات النامية) على متوسط حسابي 2.7 وبمستوى متوسط وانحراف معياري مقداره (831.). وتثير الدلالات الإحصائية المبينة أن ثمة ارتباطا واضحا بين الفقرات. لا سيما أن مستوى الدلالة الفا كان (>5, ). وللمستويات كافة، تلاها فقرة تثكيل قواسم مشتركة بين المجتمعات الإنسانية بمتوسط حسابي مقداره 2,44 وانحراف معياري مقداره 767,. بينما جاءت فقرة التبادل الثقافي بين المجتمعات الإنسانية بمتوسط حسابي مقداره 2.4 وبمستوى متوسط وانحراف معياري مقداره 752. وتدل الدلالات الإحصائية أن ثمة ارتباطا واضحا بين الفقرات. لا سيما أن مستوى الدلالة الفا كان (>5, ) وللمستويات كافة، تلاها فقرتا تجسير فوهة المعرفة بين بني البشر، والتبادل الثقافي والفكري بين الثقافات الإنسانية. لا سيما أن مستوى الدلالة الفا كان (>5, ) وللمستويات كافة, والتي تدل على وجود علاقة إيجابية بين زيادة التعرض لتقنيات الإعلام الرقمي وبين التأثر بالمضامين الخاصة بهذه الفرضية.

- ولغاية التعرف على مستويات المعرفة لاى عينة الدراسة حول أولويات حمايتهم من تأثير الإعلام الرقمي وتدفق المعلومات المفتوح جاء المحور الثاني والمتعلق بحماية الإنسان من سلبيات الإعلام الرقمي، الذي يجيب عن سؤال الدراسة الأول السابق وفرضيته. وبالنظر إلى الجدول والرسم البياني رقم(2) الممثل للتوزيع التكراري والنسب المئوية والمتوسطات الحسابية والانحرافات المعيارية لمدى حماية الإنسان من تأثيرات الإعلام الرقمي وبيان المتوسطات الحسابية تبين أن المتوسطات الحسابية للفقرة جائت على النحو الآتي: 
جدول رقم (2) لمجموع التكرارات ونسبها حول سؤال من يحي الانسان من تأثيرات الإعلام الرقمي؟

\begin{tabular}{|c|c|c|c|c|}
\hline الانحراف المعياري & المتوسط الحسابي & 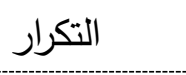 & 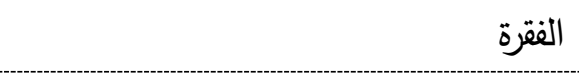 & ترتيب الفقرة \\
\hline .811 & 2.38 & 59 & تحفيز دور التشريعات & 8 \\
\hline .962 & 2.9 & 94 & تنفيذ مشاريع إعلامية إممية وفق نظرية & 3 \\
\hline ,882 & 2.48 & 73 & للإِعلام الرقمي العام بالتأثير الإيجابي والسلبي & 6 \\
\hline .954 & 2.7 & 89 & تأطير السياسات الإعلامية بالمسؤولية & 4 \\
\hline 1 & 3.5 & 125 & توسيع قاعدة التربية الإعلامية & 1 \\
\hline .766 & 2.32 & 55 & تقعيل دور المؤسسات الدولية لمراقبة & 9 \\
\hline .835 & 2.42 & 65 & تبادل الخبرات والتجارب العالمية & 7 \\
\hline .730 & 2.27 & 59 & تنفيذ مشاريع إعلامية أممية & 10 \\
\hline .983 & 3 & 99 & وضلع برامج للتوعية المجتمعات بالطرق & 2 \\
\hline .930 & 2.6 & 82 & تعظيم تنظيم دور مؤسسات حقوق & 5 \\
\hline & & 470 & & \\
\hline
\end{tabular}

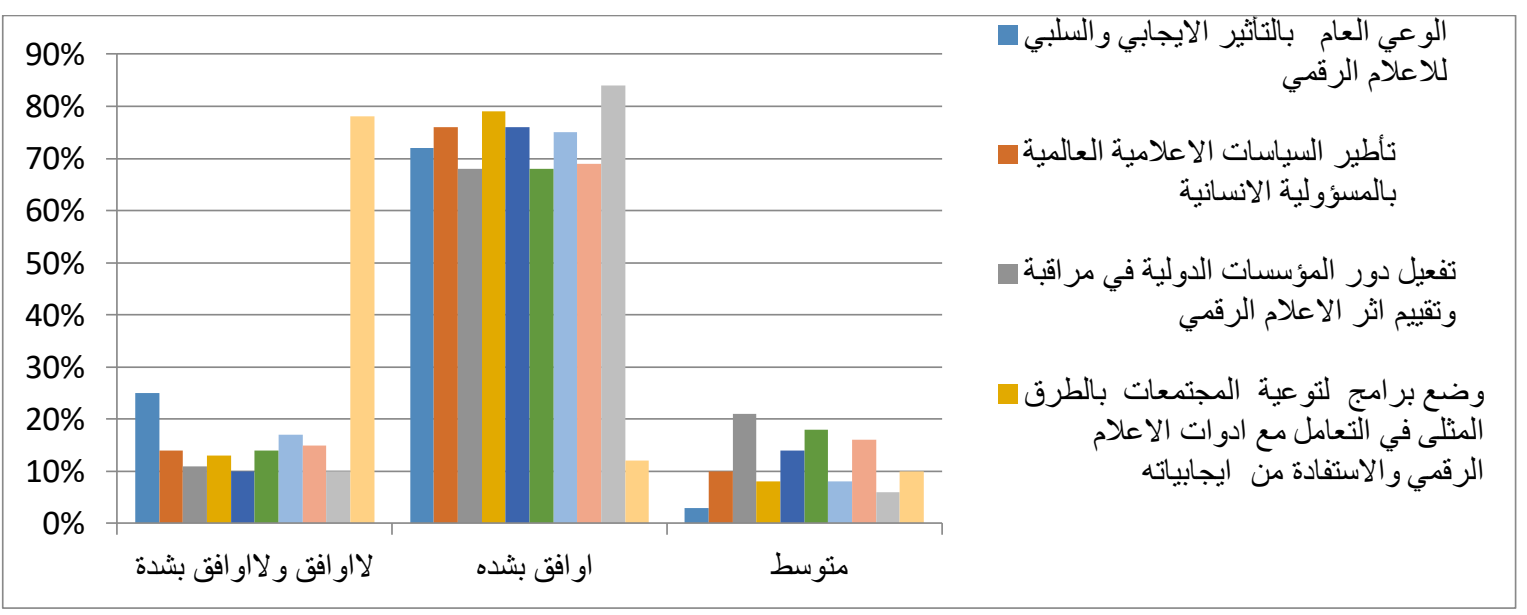

رسم بياني (2) لمجموع التكرارات ونسبها حول سؤال: من يحمي الانسان من تأثيرات الإعلام الرقي؟؟ 
بلغ توسيع قاعدة التربية الإعلامية (3.5) وبأعلى متوسط حسابي وبانحراف معياري مقداره (1) - في حين حصلت فقرة تتفيذ مشاريع إعلامية أممية وفق نظرية المسؤولية الإنسانية بمتوسط حسابي (2.27) وهي الأقل وبانحراف معياري مقداره( 73, ) . مما يشير إلى أن ثمة ارتباطا واضحا بين الفقرات الفرضية. وللوقوف على المقارنات بين

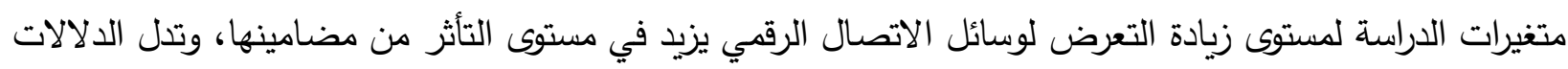
الإحصائية أن ثمة ارتباطا واضحا بين الفقرات. لا سيما أن مستوى الدلالة الفا كان (>5, ) وللمستويات كافة، فقد تبين

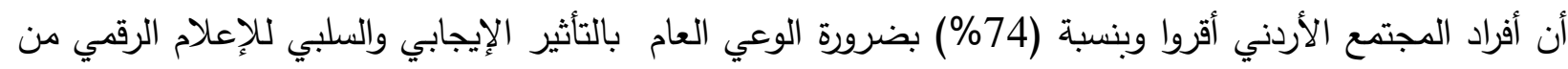
خلال التركيز على التربية الإعلامية، ونظرته نحو دور عالمي قائم على تأطير السياسات الإعلامية العالمية بالمسؤولية

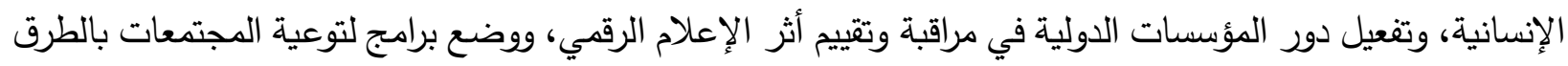
المثلى في التعامل مع أدوات الإعلام الرقمي والاستفادة من إيجابياته، تتظيم وتعظيم دور مؤسسات حقوق الإنسان

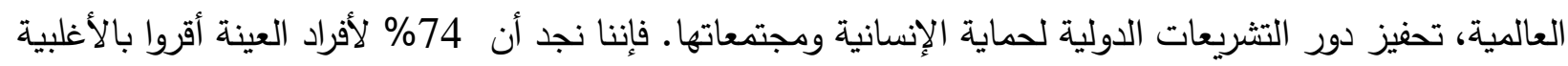
القصوى الأجراءات العلمية اللازم اتخاذها في سبيل مواجهة تأثيرات الإعلام الرقمي، لا سيما ونحن نتحدث عن أهمية

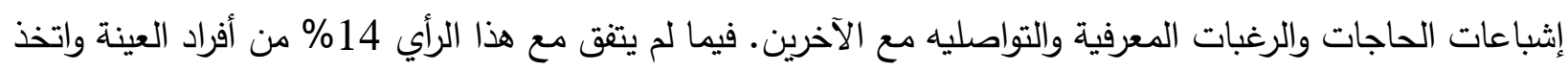
12\% موقف الوسط لعدم المعرفة الكاملة بمثل هذه القضايا أو لعدم القدرة على تكوين الرأي.

ثانيًا - سؤال الدراسة الثاني الذي يتعلق بالوسيلة الرقمية الأكثر استخدامًا وتأثيرًا في زيادة التوعية لطلبة المدارس والجامعات والمجتمع بخصوص تقليل الأثار السلبية للتقنيات الرقمية وفرضيته الوسيلة الرقمية الأكثر استخدامًا، هي الأكثر تأثيرًا على عينة الدراسة أثناء تلبية الحاجات والرغبات المعرفية ونظرة أفراد العينة إلى الوسيلة الأفضل، حيث تم الإجابة عنه بالمحاور الآتية: الأول: الوسيلة الأكثر رغبة في إشباع الحاجات. ومن خلا الجداول والرسم البياني رقم( 3) وتحليل البيانات التكرارية ونسبها ومقاييس النزعة المركزية يتبين:

أن 33\% من أفراد العينة يستخدمون الفيس بوك وسيلة أولى من بين تقنيات الإعلام الرقمي وبمتوسط حسابي 3.2 وانحراف معياري985. ولا سيما من الإناث والثرائح العمرية بين( 15-45) وبمستويات علمية من حملة درجة البكالوريوس من الموظفين وطلبة الجامعات والمدارس والإعلاميين. بينما مثل الهشتاغ والتوتر ما نسبته على التوالي ( 11\%،9\%) وبمتوسط حسابي على التوالي (2,6، 254) وبانحراف معياري على التوالي (685. و 672.). يليها الواتساب بنسبة 20\%، وبمتوسط حسابي 2,8 وبانحراف معياري 887. ومثّل الطلبة في الجامعات لا سيما الفئات العمرية في المرحلة الجامعية (20-45)، وأساتذة الجامعات وتميز عند الذكور أكثر من الإناث. يليها اليوتيوب14\% الذي يفضله الطلبة في الأعمار من ( 15-30) ومن الذكور وبالمستويات العلمية في المدرسة والجامعة. يليها الماسنجر (13\%) الذي يفضله الذكور أكثر من الإناث ولا سيما من الإعلاميين والموظفين وأساتذة الجامعات، وحملة الثهادات العليا، ومن الأعمار التي تتراوح ما بين 30 - 56 سنة. 
جدول (رقم 3) الوسيلة الرقمية الأكثر استخداما وتأثيرها في زيادة التوعية لطلبة المدارس والجامعات والمجتمع

\begin{tabular}{|c|c|c|c|c|}
\hline الانحراف لمعياري & :الوسط الحسابي & وموافق بثده & | الفقرة & رقم الفقرة \\
\hline .985 & 3.2 & 180 & الفيس بوك & 1 \\
\hline .685 & 2.6 & 61 & هاشتاغ & 5 \\
\hline .672 & 2.54 & 49 & التويتر & 6 \\
\hline .887 & 2.8 & 103 & | الواتساب & 2 \\
\hline .831 & 2.6 & 73 & اليوتيوب & 3 \\
\hline \multirow[t]{2}{*}{.788} & 2.4 & 73 & |الماسنجر & 4 \\
\hline & & 545 & & المجموع \\
\hline
\end{tabular}

الرسم البياني (رقم 3) الوسيلة الرقمية الأكثر استخداما وتأثيرها في زيادة التوعية لطلبة المدارس والجامعات والمجتمع

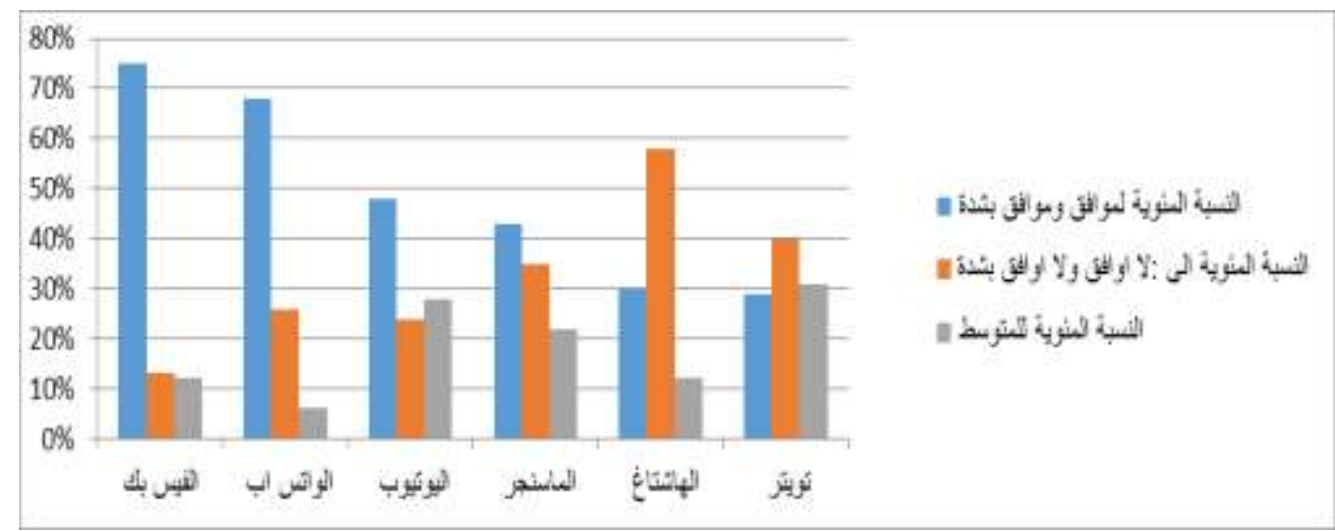

المحور الثاني: ويتعلق بمدة التعرض للوسائل الرقمية: من خلال الرسم البياني رقم( 4) والتحليل الرقمي للتكرارات الإحصائية المتعلقة بأجوبة أفراد العينة على أفضل الفترات المرغوبة في استخدام تقنيات النت لإشباع الحاجات والرغبات المعرفية تبين أن: 31\% من أفراد العينة يفضلون استخدام وسائل الإعلام الرقمية قبل النوم وبمتوسط حسابي مقداره 3.2 وانحراف معياري 852. ولا سيما عند الثباب من الجنسين في المرحلة العمرية ما بين (20-25)..

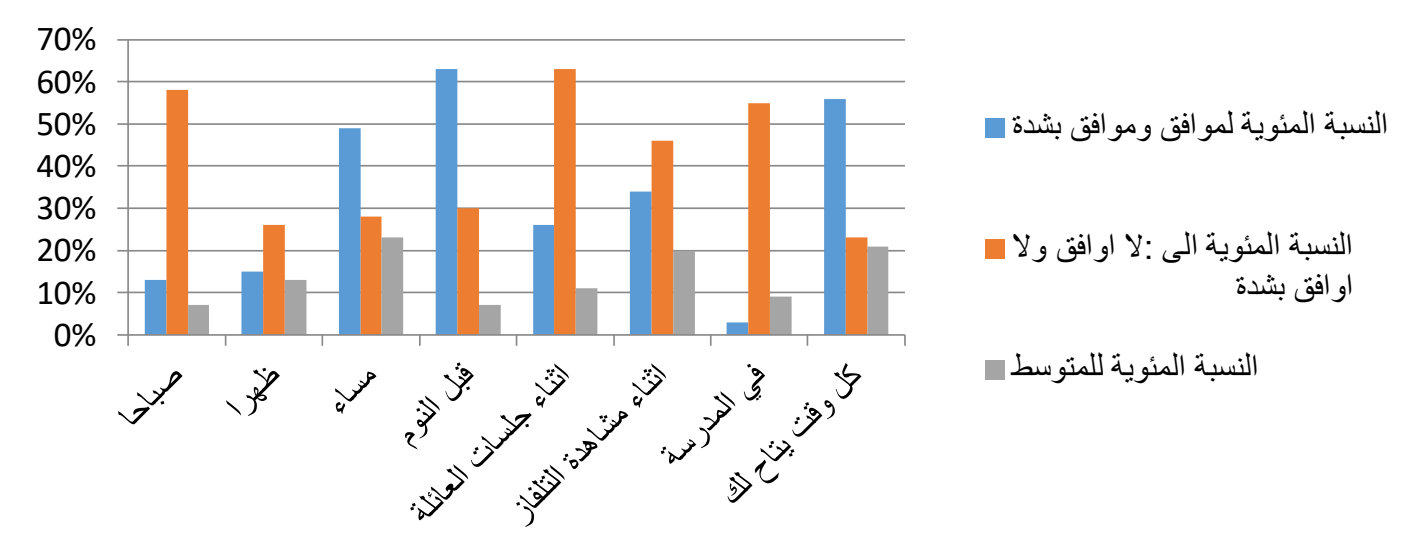




\section{رسم بياني رقم ( 4 ) التكرار الإحصائي حول التوقيت المفضل في استخدام أدوات الإعلام الرقمي}

في حين نجد أن خيارات الاستخدام في المدرسة أو أثناء مشادة التلفاز هي الأضعف وبلغت 8\% . وبمتوسط حسابي 2.1 2.1

-26\% من أفراد المجتمع الأردني يقرون استخدامه كلما اتيحت الفرصة وبمتوسط حسابي 2.26، وانحراف معياري

- بينما يفضل 21\% من أفراد العينة استخدامه في المساء وبمتوسط حسابي 2.5 وانحراف معياري 762. - في حين تزداد النسبة أثناء الجلوس مع العائلة وبنسبة 12\%. بمتوسط حسابي 2.3 وبانحراف معياري 626.

ثالثًا - سؤال الدراسة الثالث المتعلق بالتعامل الصحي للتقنيات الرقمية بفترات ونوعية مناسبة يعزز الفوائد الإيجابية

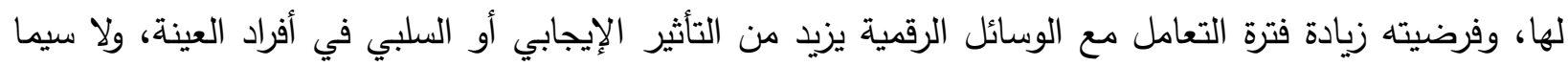

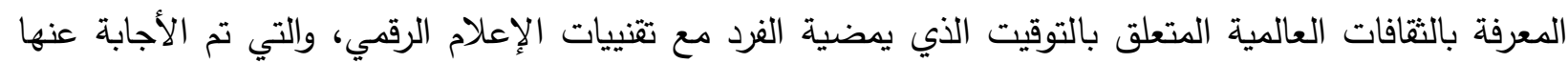
ضمن المحاور الآتية : فترة التعرض للوسيلة الرقمية : من خلال الوصف التحليلي الكمي لتكرارات العينة وتحليلها, والموضحة نسبها بالرسم البياني (رقم 5)، والإجابة على الفرضية. التعامل الصحي للتقنيات الرقمية وبفترات مناسبة يعزز الفوائد الإيجابية والأثار السلبية لها، ولا سيما لإشباع الحاجات المعرفية بالثقافات العالمية، وباستخدام المعايير والمقاييس الإحصائية وتكراراتها حسب معامل بيرسون وشيفية، وظهور مستوى الدلالة عند (>5, ) وللمستويات كافة، فقد تبين أن :

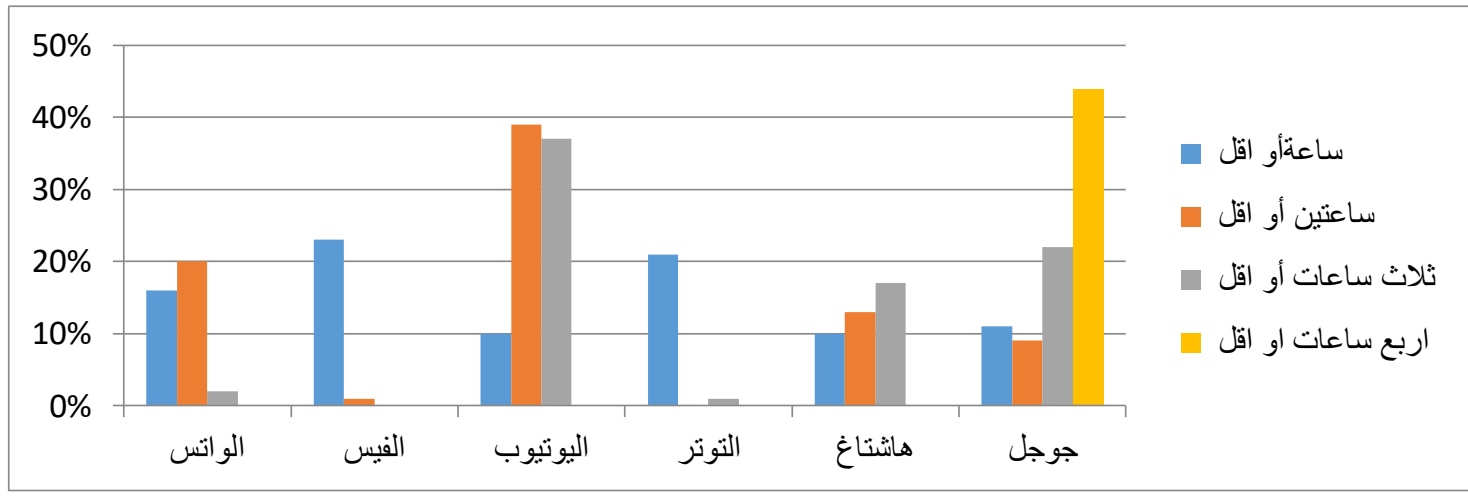

الرسم البياني رقم (5) نسب توزيع التكرارات الإحصائية على أفراد العينة حول الوقت الذى يمضية في التعامل مع النت : ساعة/يوميا

- 35\% من أفراد العينة يمضون ساعة أو أقل يوميًا في التعامل مع وسائل الإعلام الرقمي وبمتوسط حسابي 2.9 وانحراف معياري ( 788. ) - 19\% من أفراد العينة يمضون ثلاثة ساعات أو أقل يوميًا مع وسائل الإعلام الرقمي وبمتوسط حسابي 2.1 وانحراف معياري 721. معظمهم من الفئات العمرية( 15-25) الذكور ومن طلبة المدارس والجامعات. 
أما الفئة العمرية (25-56) الذكور فما نسبته 25 \% من أفراد العينة يمضون ساعتين أو أقل يوميًا مع وسائل الإعلام الرقمي بمتوسط حسابي 2.5، وانحراف معياري 676. في حين 20\% من أفراد العينة يمضون 4 ساعات أو أقل، وبمتوسط حسابي مقداره 2.3, وانحراف معياري 776. وتتركز على استخدامات (جوجل). وتبين أن أساتذة الجامعات والمعلمين والإعلاميين قد يمضون في البحث عن المعلومات ما يزيد عن ذلك ولكن بنسب قليلة. تعكس جميع الوسائل استخدامات متفاوته بين شرائح العينة تبعًا لمهنة كل شريحة واهتماماتها، ولم يظهر حتى الآن سلوكيات متعصبة لوسيلة أو حالة إدمان، أو حالة مرضية تميز وسيلة عن وسيلة مما يؤكد أهمية الإسراع بالتربية الإعلامية - - المحور الثاني: نوعية البرامج التي يفضلها الفرد في استخدامه للتقنيات الرقمية. وبالرجوع للرسم البياني رقم (6) يتبين أن : 32\% من أفراد العينة يفضلون البرامج الترفيهية كأولوية للبرامج التي يتابعونها على وسائل الإعلام الرقمية, ولا سيما الألعاب الإلكترونية، والرياضة والبرامج الدرامية والأفلام وغيرها وبمتوسط حسابي 2.9 وبانحراف معياري 823. بينما لا يفضل34\% منهم هذه البرامج، واختار 20\% حالة الوسط أي عدم اتخاذ القرار بذلك. ومعظم هذه الثريحة من الطلبة التي تتراوح أعمارهم بين (15-25) ومن الذكور وبمستويات علمية لطلبة المدارس والجامعات. (28\%) من أفراد العينة يفضلون البرامج الثقافية والفكرية والدينية وبمتوسط حسابي 2.6 وانحراف معياري 796. وتمثلت بأساتذة الجامعات والمعلمين والإعلاميين والمتقاعدين. - 26\% من أفراد العينة يفضلون البرامج السياسية وبمتوسط حسابي مقداره 2.3 وانحراف معياري 754. وتمثل بالإعلاميين وأساتذة الجامعات والمعلمين والمتقاعدين والموظفين. -16\% من أفراد العينة يفضلون البرامج التنموية والبيئية وبمتوسط حسابي 2، وانحراف معياري 676. وتمثلت بالمتقاعدين والمعلمين.

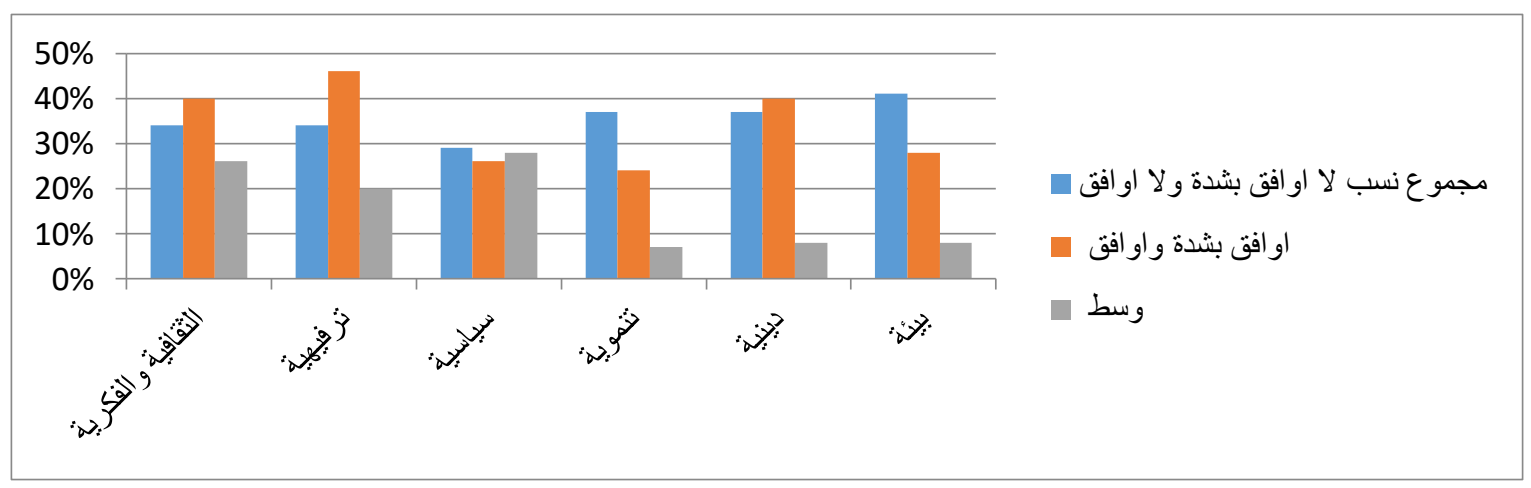

\section{الرسم البياني رقم (6) نسب مجموع التوزيع التكراري لأفراد العينة والمتعلق بأهم البرامج التي تركز عليها في استخدام تقنيات الإعلام الرقمي}

رابعًا _ سؤال الدراسة الرابع، ومقتضاه: هل التمكن من وسائل الإعلام الرقمي بالتربية الإعلامية تسهل عملية الإشباع المعرفي وتقنياته يزيد من فرصها بمواجهة تحيدات المستقبل، وتشبع رغباته المعرفية في صناعة المستقبل والتهيؤ له. فكما هو موضح بالرسم البياني رقم ( 7 ) وبعد إجراء الحسابات المتعلقة بالتكرارات الإحصائية فقد تم الإجبة عنه من رنديات 


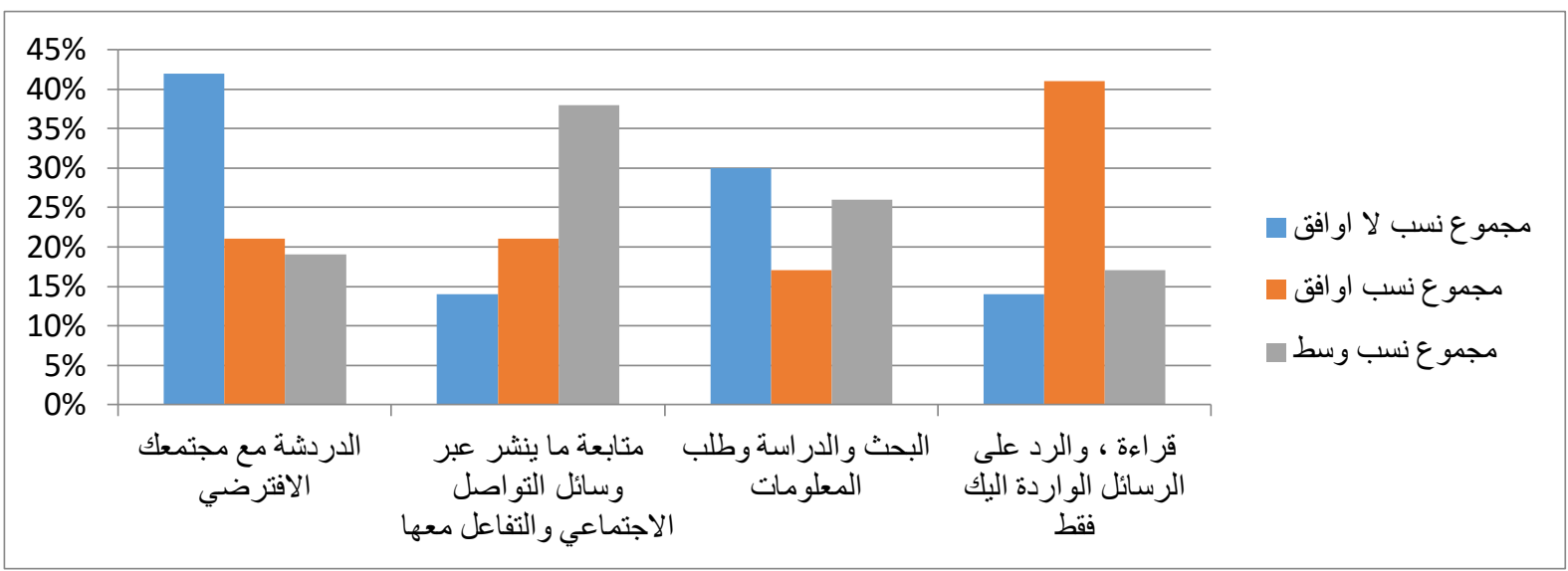

الرسم البياني رقم (7) لتوزيع نسب المجموع التكراري لرأي العينة على سؤال :غالبية الأوقات التي تمضيها على النت تكون في؟ الدحور الأول: أسباب استخدام الوسائل الرقمية، وقد بينت الدراسة أن:

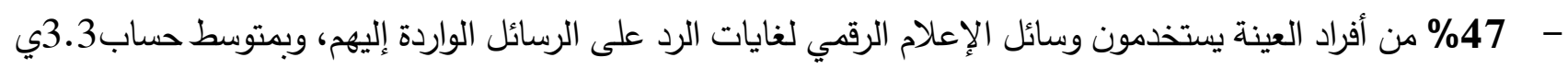

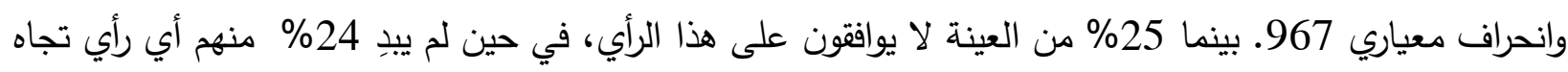

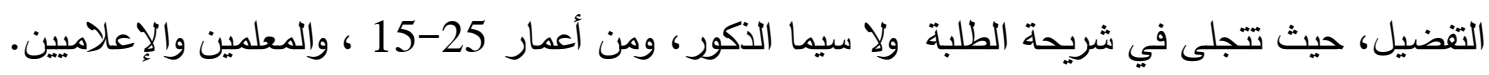

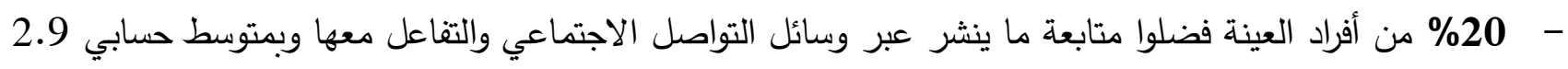

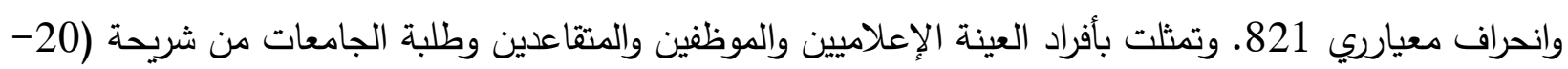

19\% من أفراد العينة اختاروا الدردشة مع المجتمع الافتراضي وبمتوسط حسابي2,7 وانحراف معياري 801. وتمثلت بطلبة المدارس والجامعات والموظفين ولا سيما الإناث، والمعلدين.

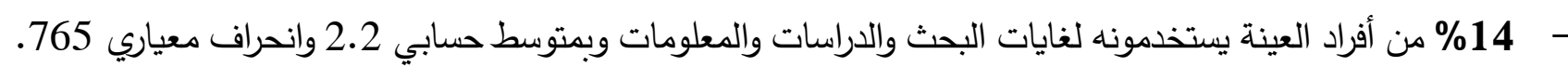
وتتمثل في الإعلاميين وطلبة الجامعات والمعلمين.

- المحور الثاني: جغرافية مصادر المعلومات والتعامل معها بالابتكار والتحليل والنقد والانتاج الرقمي، وحول جغرافية

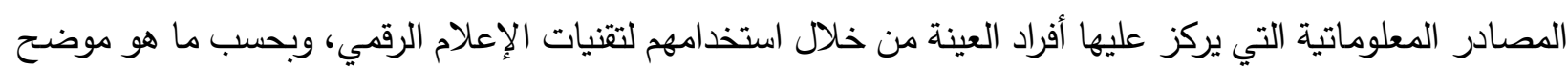

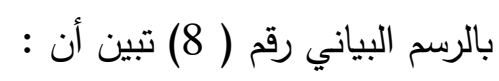




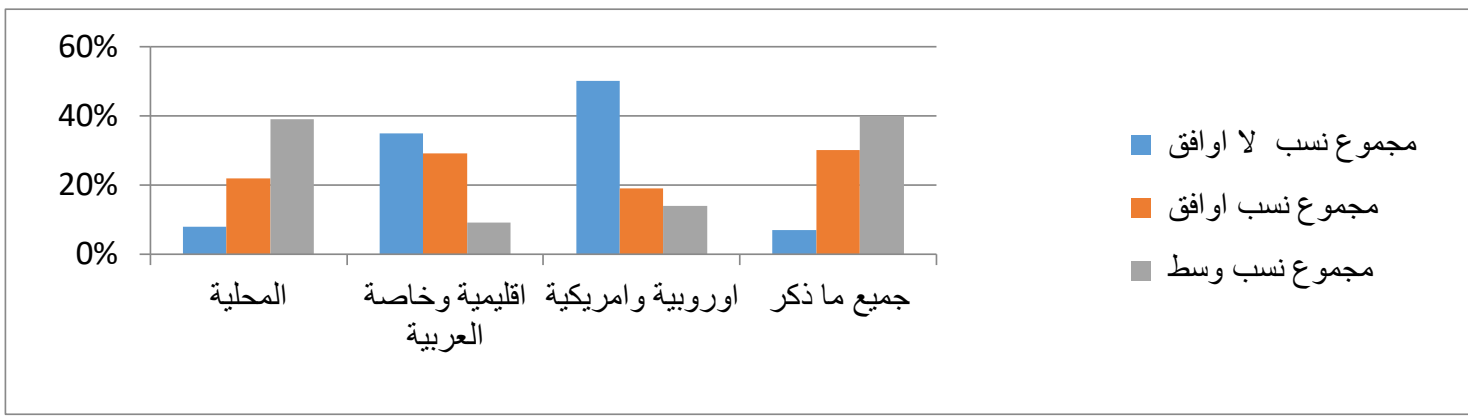

رسم بياني رقم (8) لنسب التوزيع التكراري لكصادر الموضوعات التي يركز عليها أفراد العينة في أولوياتهم في وسائل الإعلام الرقمي (النت) - 34 \% من أفراد العينة يفضلون الدصادر الأقليمية والعربية كأولوية (الجزيرة, العربية, أم بي سي، روتانا....إلخ)

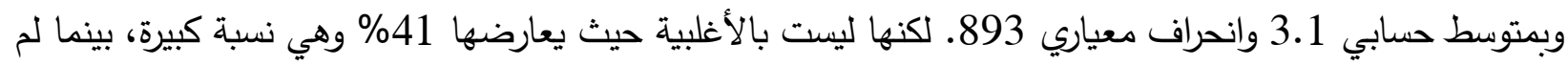

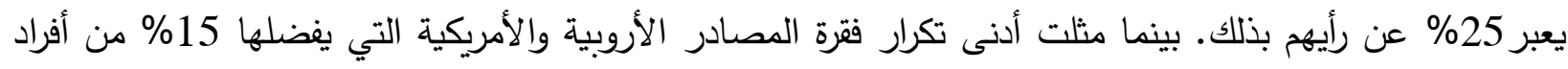

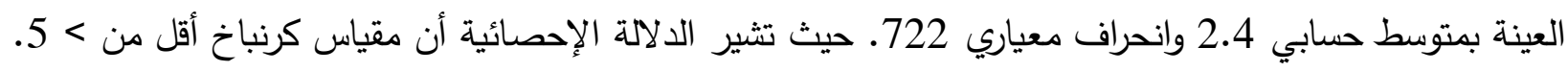
مما يؤكد وجود علاقة طردية إيجابية لإثباع الرغبات وتلبية الحاجات المعرفية ما بين زيادة التعرض للوسيلة المحببة يزيد من التأثير في أفراد العينة 28\% من أفراد العين اختاروا المصادر المحلية وهي الترتيب الثالث حسب معدل التكرارات وبمتوسط حسابي 2.7

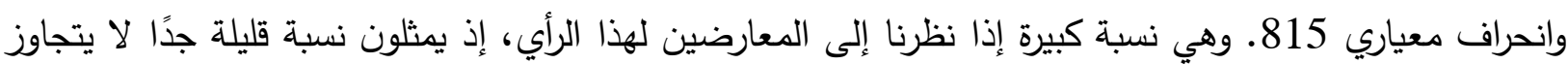
\% \% و ولهذا فإن المصادر المحلية تعدّ مهمة بالنسبة للمجتمع الأردني.

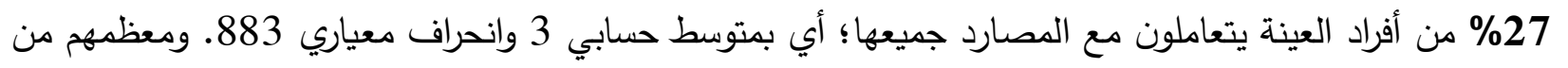
الإعلاميين والموظفين والمعلمين ولا سيما الإناث.

\section{المحور الثاني :أدوات مواجهة الأثار السلبية للإعلام الرقمي:}

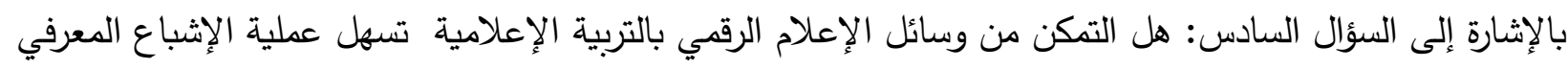

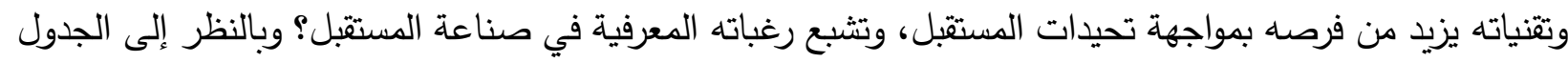

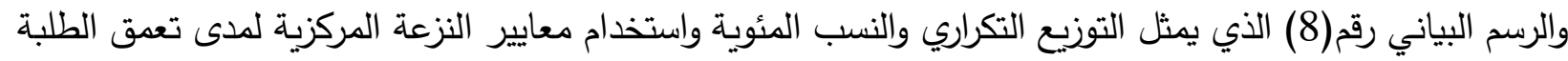

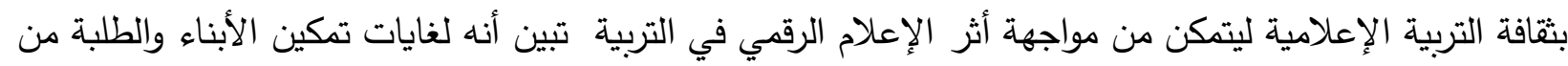

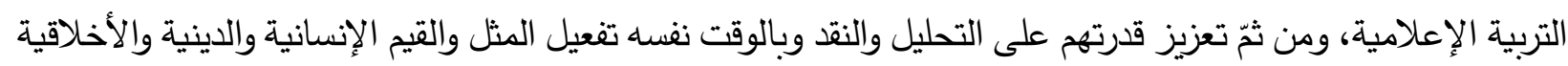

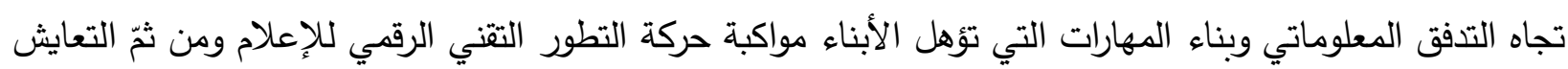

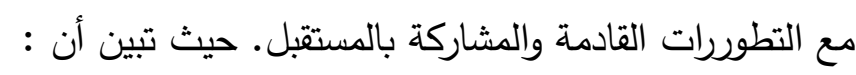
- 93\% من أفراد العينة يؤيدون قيام الآباء على التواصل الدائم مع الأبناء والتعرف على بلى السلوكيات الرقمية وتقهم مطالبهم، وجاءت الفقرة بمتوسط حسابي 3 وانحراف معياري 904.

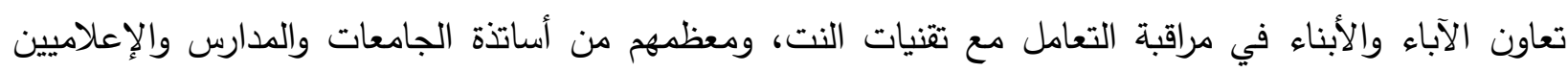
والمتقاعدين ولا سيما الذكور ، في حين عارض هذه الفكرة 7\% من أفراد العينة جلهم من الطلبة في الجامعات. 


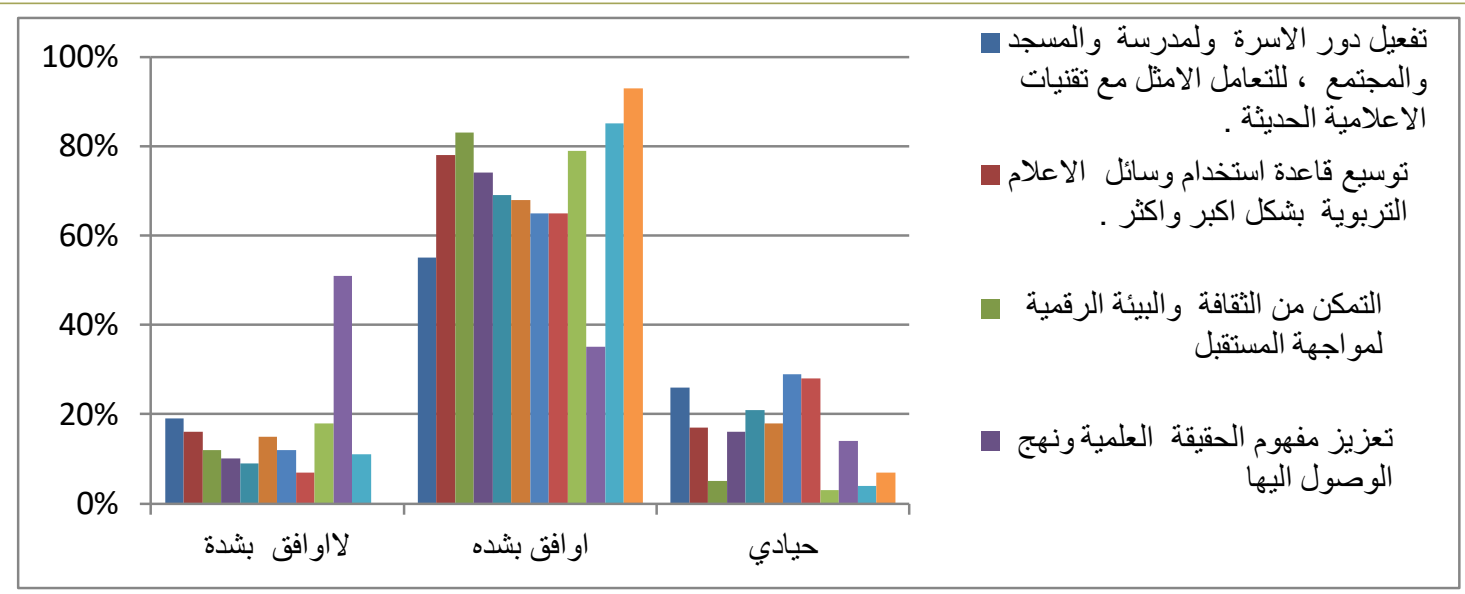

رسم بياني رقم (8) مجموع التكرارات والنسب لمدى التعمق بثقافة التربية الإعلامية لتمكين الطالب من مواجهة أثر الإعلام الرقمي في التربية

-85 من العينة أيدوا عملية توعية الأبناء بوجود أصحاب أيدولوجيات وبأهداف غير سليمة وبمتوسط حسابي 2.9

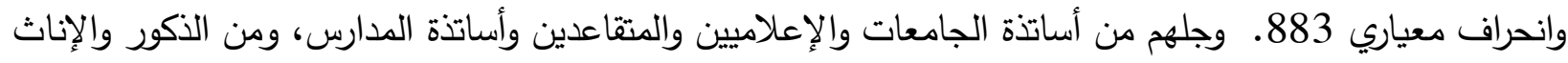

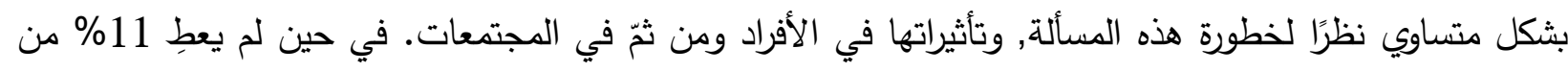

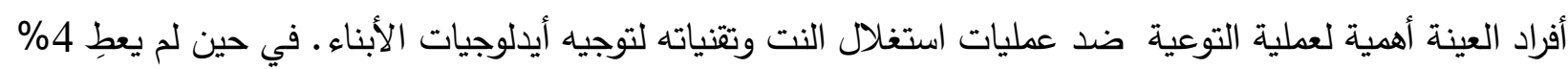
من أفراد العينة أي رأي تجاه ذلك. -79\% من أفراد العينة أيدوا بثدة دعوة المجتمعات والأسر لترسيخ قيم اللقاءات والحوار والنقاش وتبادل وجهات النظر، كأحد أدوات التربية الإعلامية الدشاركة في المستقبل, وكان معظمهم من الأساتذة وبمتوسط حسابي 2.8 وانحراف معياري 873. - 75 م من أفراد العينة أكدوا ضرورة التمكن من الثقافة والتربية الإعلامية الرقمية لمواجهة مخاطرها وبمتوسط حسابي

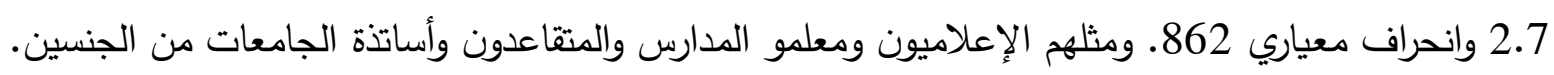

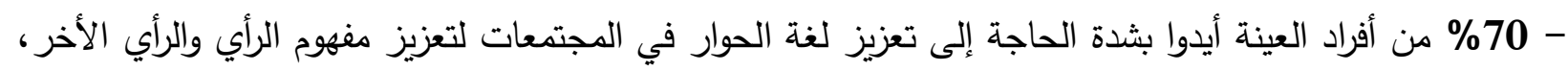

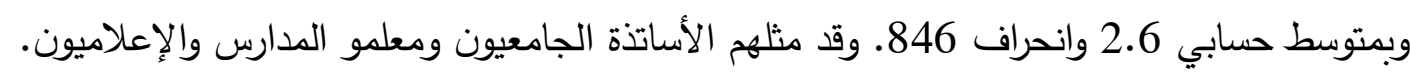

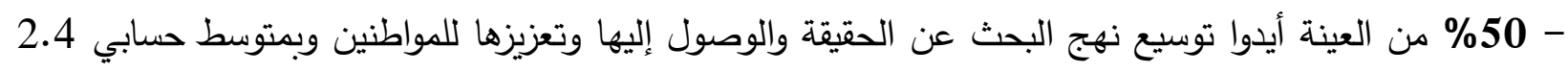
وانحراف معياري 821. ويمثلهم الإعلامييون والمعلمون الذكور والإناث والمنتقاعدون.

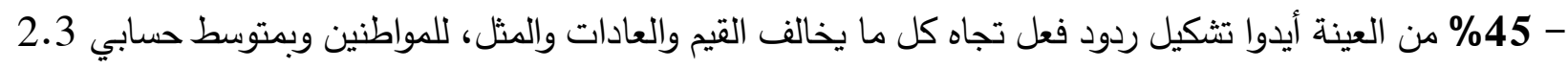
وانحراف معياري 783. ونيمثلهم الإعلامييون والمعلمون الذكور والإناث والمتقاعدون.

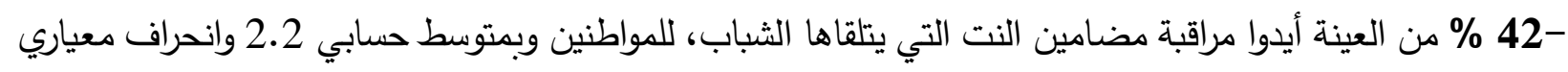
791. ويمثلهم الإعلامييون والمعلمون الذكور والإناث والمتقاعدون.

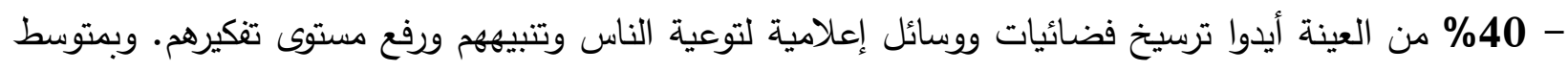
حسابي 2.1 وانحراف معياري 765. ويمثلهم الإعلامييون والمعلمون الذكور والإناث والمتقاعدون. 
المحور الثالث : أدوات الوسائل الرقمية الأكثر استخداما عند أفراد العينة لتحديد الوسيلة الأكثر تأثيرا. وفيما يتعلق بالوسيلة الأولى التي يفضلها أفراد المجتمع الأردني لممارسة سلوكاته التواصلية, من بين تقنيات الإعلام الرقيم, فقد اختار المجتمع الأردني، وكما هو موضح بالرسم البياني رقم(9):

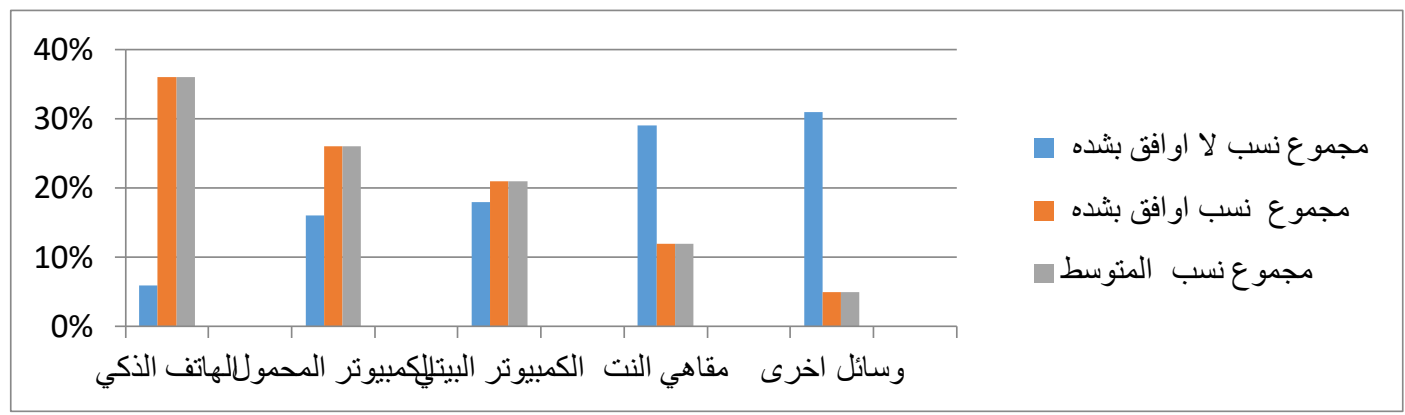

الرسم البياني رقم (10) لنسب المجموع التكراري واتجاهاته لسؤال: أكثر تقنيات أدوات الإعلام الرقمي استخداما

-الهاتف الذكي وسيلة أولى، إذ تستخدم للتواصل وإجراء الأعمال الإكترونية المعنية بنسبة 34\% وبمتوسط حسابي 3.1 وانحراف معياري 898. ومعظمهم من طلبة الجامعات والمدارس والمتقاعدين، في حين جاءت فقرة وسائل أخرى أقل الخيارات وبنسبة 5\% من التكرارات وبمتوسط حسابي 2,2, وانحراف 684. ومعظمه من الصحفيين. ومن خلال الدلالات الإحصائية وحسب مقياس كرنباخ التي تثير إلى أقل من> 5. مما يؤكد وجود علاقة بين الفقرات ويعزز التقارب حول آراء العينة حسب المتغيرات الديمغرافية, اختارت العينة الكمبيوتر المنزلي بنسبة 25\% وبمتوسط حسابي مقداره 2.8 وبأن حراف معياري 867. معظمهم من الموظفين وأساتذة الجامعات وجزء من المعلمين. وجاء خيار الكمبيوتر المحمول بنسبة 24\% وبمتوسط حسابي 2.1 وانحراف 853. معظمهم من أساذة الجامعات والمعمين والصحفيين. ثم جاء خيار مقاهي النت الخيار الرابع وبنسبة 12\%.

خامسًا : سؤال الدراسة الخامس: هل تعزز ثثقة أفراد العينة بتقنية تواصلية معينة مفاهيم التربية الإعلامية، ولا سيما قدرة الطلبة على النقد والاستجابة الإيجابية معها. وفرضيتها : ثقة أفراد العينة بتقنية تواصلية معينة تعزز مفاهيم التربية الإعلامية ولا سيما قدرة الطلبة على النقد والاستجابة الإيجابية. وللإجابة عن السؤال وفرضيته ومن خلال التحليل الاحصائي لتكرارات أفراد العينة وتطبيق الدلالات الأحصائية ومقياس كرنباخ فقد تبين أن المقياس ما دون 5. مما يؤكد وجود ارتباط إيجابي بين الفقرات، وقد تم الإجابة بالمحاور الآتية : - المحور الأول: نوع الوسيلة الأكثر قناعة لأفراد العينة بالمعرفة من خلال تحليل ونقد مضامينها وبالتالي الاستفادة منها. ووفقا للرسم البياني رقم(11)، فقد تبين أن :- التلفزة الخاصة تتمتع بالنسبة الأكبر وبنسبة 15\% وبمتوسط حسابي 2.9 وانحراف معياري 685. ومعظمه من المعلمين والموظفين والمتقاعدين الذكور خاصّة. في حين جاءت فقرة الإذاعة والتلفزة الرسمية الأقل اختيارًا وبنسبة 9\% وبمتوسط حسابي 2,1 وانحراف معياري 623. ومعظمهم من الإعلاميين والمعلمين الإناث. في حين جاءت فقرة الإذاعات الخاصة بنسبة 14\% وبمتوسط حسابي 2.7 وانحراف معياري 662. وجلهم من الموظفين والمتقاعدين الإناث كذلك. بينما اختار 11\% من أفراد العينة الصحف الإكترونية 
والصحف الورقية بالترتيب نفسه، وبمتوسط حسابي 2.6 وانحراف معياري 648. ويمثلهم المتقاعدون وأساتذة الجامعات

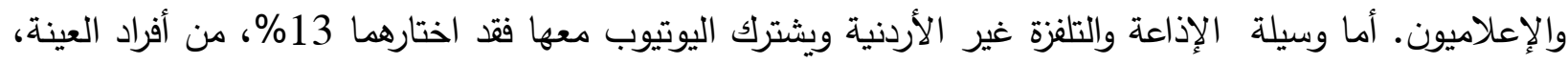
وبمتوسط حسابي 2,7 وانحراف معياري 658. وجلهم من أساتذة الجامعات وطلبة الجامعات والإعلاميين الذكور والإناث بالنسبة نفسها.

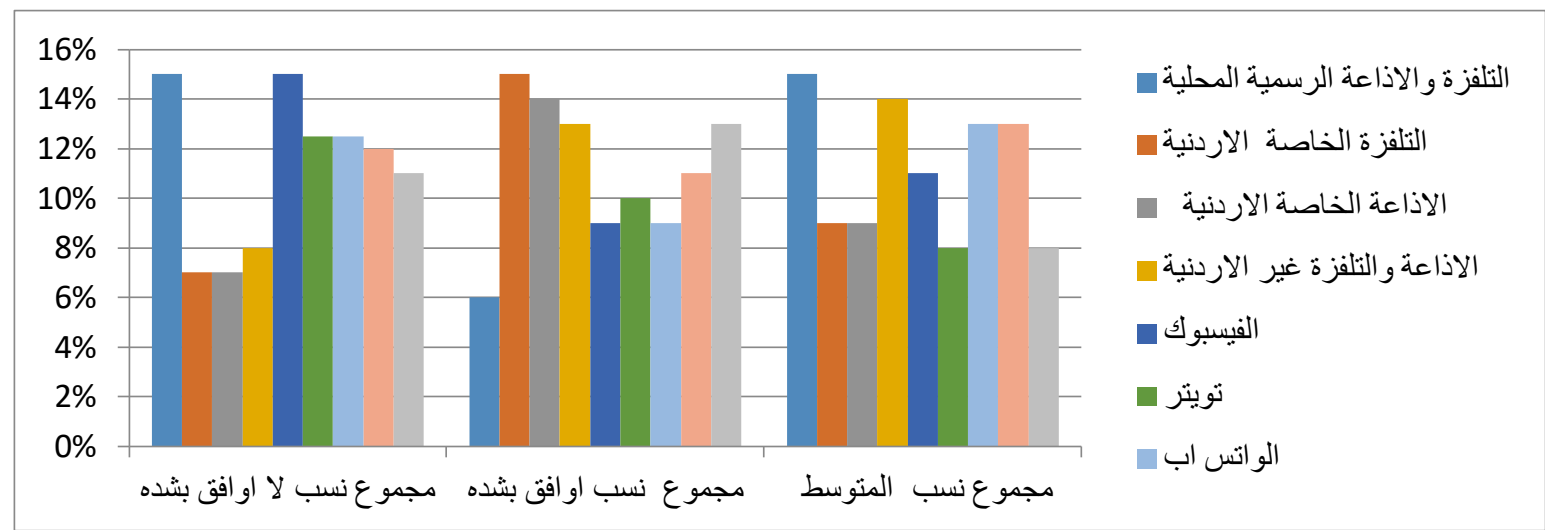

رسم بياني رقم (10) مجموع التكرارات ونسب آراء العينة للتقنية الأكثر مصداقية .

غير أن أفراد العينة وبنسبة 12\% اختاروا الهاشتاق، وجلهم من الموظفين الإناث والمعلمين والموظفين ولا سيما الإناث. ورأى 10\% من أفراد العينة أن التويتر يمثل لهم الوسيلة الأكثر قدرة للتعلم والمعرفة التي تمكنهم من النقد والتحليل وتصب في إطار إشباع الحاجات والإشباعات المعرفية والنقدية.

المحور الثاني: يتعلق بمضامين وسائل الإعلام الفضائية: ففي إطار سؤال الدراسة: هل تعزز ثقافة التربية الإعلامية باختيار الوسيلة الفضلى التي تمكنه من النقد والاستجابة الإيجابية، وفرضيتها، وفي إطار دور الفضائيات في تعزيز مهارة الفرد في النقد والاستجابة الإيجابية، وبالنظر إلى إلى الرسم البياني رقم(10) ومن خلا التحليل الإحصائي لتكرارات أفراد العينة تبين أن: وفير

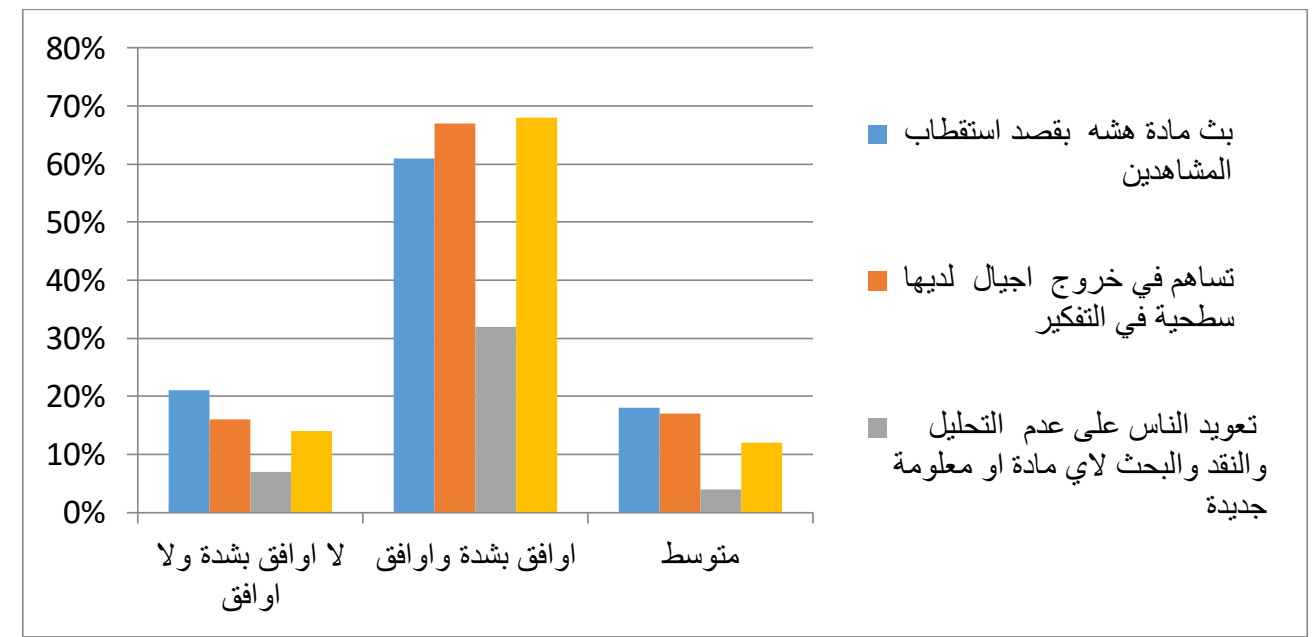

رسم بياني رقم (10) مدى دور الفضائيات في تعزيز مهارة الفرد في النقد والاستجابة الإيجابية 
- 31\% من أفراد العينة - وأغلبهم من الوسط التربوي التعليمي والمتقاعدين الإناث - يقرّون بأن الفضائيات لا تمكّن الثباب من التأقلم مع تغيرات التطور والتنمية التكنلوجية وبمتوسط حسابي 3.3، وانحراف معياري مقدارة 895. - - في حين جاءت فقرة (تعويد الناس على عدم التحليل والنقد والبحث عن أي معلومة متلقاه) في أدنى مستويات الاختيار وبنسبة 11\% وبمتوسط حسابي 2.1 وانحراف معياري 686. وتمثّل المتقاعدين وأساتذة المدارس والموظفات الإناث. وجاءت فقرة (أن التلفزة الفضائية العربية يقوم ببث مادة هشة وغير معمقة لاستقطاب المشاهدين) في الترتيب الثالث بنسبة 28\% من اختيار أفراد العينة ورأيهم بالفضائيات ودورها في إشباع رغبات أفراد العينة من دون فائدة حقيقية تذكر ، وبمتوسط حسابي 2.9 وانحراف معياري 865. - بينما أكد 30\% من أفراد العينة - وجلهم من أساتذة الجامعات وأساتذة التربية والمتقاعدين الإناث - أن الفضائيات تسهم بمضامينها في خروج أجيال ذات سطحية في التفكير والنقد التي قامت عليها مفاهيم التربية الإعلامية. وجاءت هذه الفقرة بالترتيب الثاني وبمتوسط حسابي مقداره 3 وانحراف معياري 844. المحور الثالث: سلبيات الإعلام الرقمي. ومن خلال التحليل الإحصائي لمجموع ونسب التكرارات المتعلق بالعينة، ومن خلا الدلالات الإحصائية واستخدام مقياس فيرنباخ >5. تبيّن أن العلاقة بين الفقرات ذات علاقة طردية متقاربة، والموضح بالرسم البياني رقم(11) وقد تمّ الأجابة عنه من خلال المحاور الآتية : تأثير التدفق المعلوماتي عبر الوسائل الرقمية على حياة الناس وأفكارهم. فقد تبين :

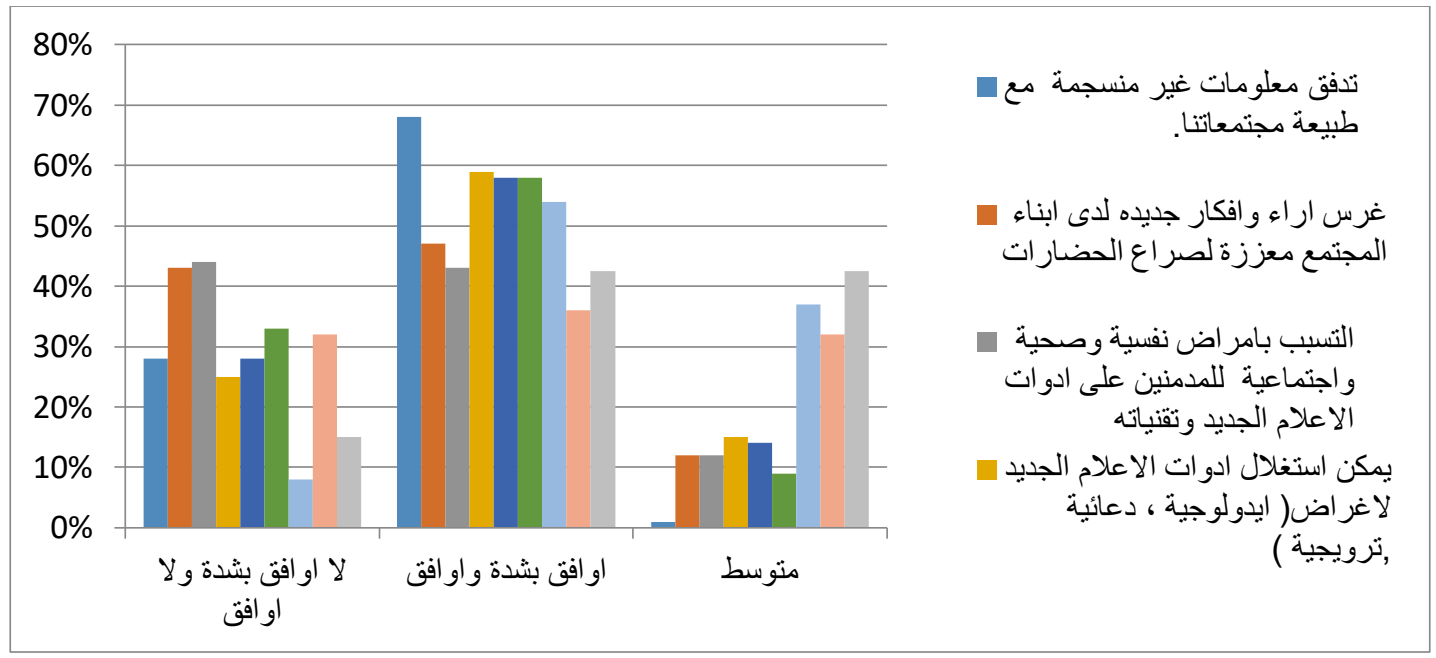

الرسم البياني رقم (11) مجموع التكرارات والنسب لسؤال يتعلق ب: سلبيات الإعلام الرقمي (الجديد)

وافق 19\% من أفراد العينة وبشدة على أن الإعلام الرقمي يسهم بتدفق معلومات غير منسجمة مع طبيعة مجتمعاتنا,

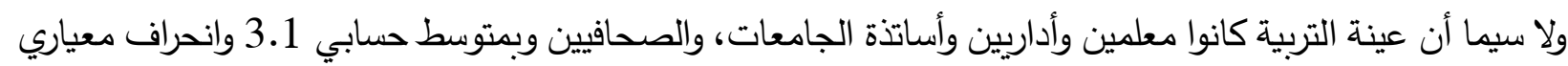
864. وهذا سينعكس سلبًا على أفكار وسلوكات الأفراد ولا سيما في مرحلة الدراسة المدرسية. في حين عارض هذا الرأي 28\% من أفراد العينة ولا سيما بعض الإعلاميين على أساس أن الوسائل الرقمية تعدّ مصدرًا معلوماتيًا كبيرًا ومصدر انفتاح على العالم الخارجي، وقد اختار 11\% من العينة خيار الوسط أي عدم اعطاء رأي . واختار 6\% من أفراد العينة فقرة التأثير على المناخ الأسري بمتوسط حسابي 2.1 وانحراف المعياري , لتأخذ بذلك على الترتيب الأخير • n و 
وأيد13\% من أفراد العينة بثدة فقرة (استخلال أدوات الإعلام الجديد لأغراض: أيدولوجية، دعائية, ترويجية)، ومثلهم الإعلاميون وأساتذة الجامعات ومعلمو المدارس والمتقاعدون. وبمتوسط حسابي 2.7 وانحراف معياري 822. في في حين لم يقبل هذا الرأي 25\% من أفراد العينة ولا سيما الموظفين وبعض الأساتذة الإناث , واختار 15\% خيار الوسط لعدم معرفتهم بهذه الأبعاد، وهم من بعض العضامة. ليليها مرتبة فقرة (التأثير على الواقع القيمي والعادات والتقاليد العامة) التي أيدها 12\% من أفراد العينة بمتوسط حسابي 2.6 وانحراف معياري 819. ومعظمه من القطاع التربوي ذكور وإناث، إضافة إلى أساتذة الجامعات والإعلاميين , بينما نجد أن 28\% من العينة لم يقبلوا هذه الفكرة، في حين لم يعِ 14\% منهم أي قرار أو رأي في ذلك. وأيد 11\% من عينة الدراسة فقرة (تعزيز السلوك المنحرف وجرائم العنف لدى المراهقين) بمتوسط حسابي 2.5 وانحراف

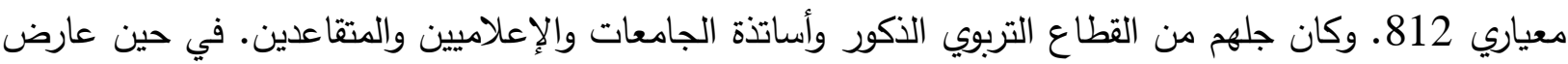
هذه الفقرة 33\% من أفراد العينة بحكم وعي الناس ومعالجة الآباء في الأسر لها. وقد اختار 9\% من أفراد العينة بثدة فقرة (الكثف عن المعلومات الثخصية التي يمكن استغلالها للسيطرة على توجهات صاحبها(سيكوماتركس)، بمتوسط حسابي 2.4 وانحراف معياري 810. من أفراد العينة، ولا سيما من الإعلاميين وأساتذة الجامعات والمهندسين • في حين غرس 15\% أفكارًا جديدة تسهم في تعزيز مفهوم صراع الحضارات بين الأفراد المتواصلين. وبمتوسط حسابي 2.9 وانحراف معياري 848. متمثلا بالأساتذة الجامعيين وطلبة الجامعات والإعلاميين. ونبّه 8\% من أفراد العينة إلى مسألة التسبب بأمراض نفسية واجتماعية وتربوية جراء الإدمان على النت. وبمتوسط حسابي 2.2 وانحراف معياري 782.

المحور الرابع : تصنيف الوسائل التي تأثر سلبا أكثر على أفراد العينة. بالنظر إلى الجدول والرسم البياني رقم(14) المتعلّق بمجموع التوزيع التكراري والنسب المئوية وباستخدام معايير النزعة

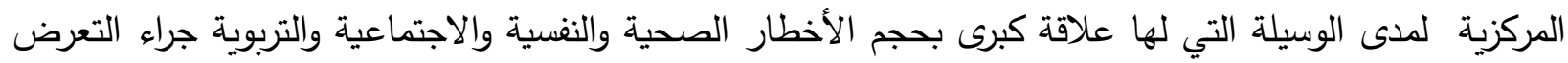

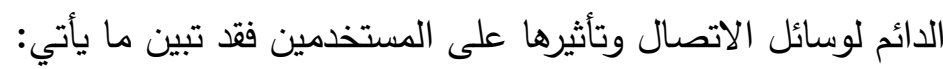

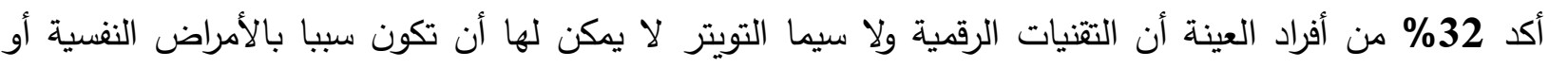
الأجتماعية وبمتوسط حسابي 2.9 وانحراف معياري 787. ومثلهم شريحة أساتذة الجامعات والصحفيين والمعلمين الذكور ، نظرًا للفائدة الكبرى التي تقدمه لأفراد المجتمع من معلومات ومعرفة متطورة وتكنلوجيا وتجارب, وأن الأمراض أساسًا تكون موجودة في نفسية المستخدم وليس من الإدمان على هذه التقنيات. وأقرّ 25\% من أفراد العينة بأن الماسنجر لا علاقة له بالأمراض النفسية والصحية التي يسببها الإدمان على وسائل الإعلام الرقمي، وهم من الطلبة وأساتذة الجامعات والمتقاعدين، بمتوسط حسابي مقدراه 2.5 وانحراف معياري 722. في حين أيّد 16\% من أفراد العينة علاقة التوتر بالأمراض النفسية والاجتماعية عند الأفراد المدمنين. وتمثل ذالك بآراء أساتذة الجامعات والإعلاميين والتربويين الإناث، بمتوسط حسابي 2 وانحراف معياري 635 وانئ ووجد 22\% من أفراد العينة أن اليوتيوب وما يوفره من برامج وأفلام تؤثّر في نفسية الأفراد وحالتهم الاجتماعية والصحية، بمتوسط حسابي 2.4 وانحراف معياري 722. كون اليوتيوب يحتاج إلى فترات زمنية أطول، إذ تزيد عن

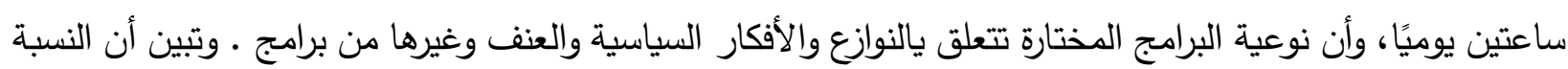
الأكبر من المؤيدين كانوا من أساتذة المدارس والإعلاميين والموظفين وأساتذة الجامعات، في حين رأى طلبة الجامعات والمدارس غير ذلك، حيث لم يوافق 28\% من أفراد العينة على هذا الطرح على أساس أن اليوتيوب وهذه التقنيات 
تعكس مدى الانفتاح والتزود المعرفي والتقني والبحثي. بينما وجد بأن 27\% من أفراد العينة لم يعطوا أي تفضيل، فاختاروا التوسط.

- - وبيّن 21\% من أفراد العينة أنّ الهاشتاغ يمثل خطرًا على الصحة النفسية والصحية والاجتماعية نظرًا لطبيعة تبادل الصور أو الإفصاح عن الكثير من الخصوصيات المتعلقة بالفرد وأسراره، وبالتالي إتاحة الاستغلال سريعًا أو استخدامها لاغراض مختلفة، بمتوسط حسابي 2,3 وانحراف معياري 716. غير أن 36\% من أفراد العينة لم يوافقوا على هذه الفرضية، ولا سيما طلبة المدارس والجامعات والإعلاميين نظرًا لأهمية تبادل الصور وتعليقاتها بالنسبة للإعلاميين، والطلبة وعلاقاتهم الثخصية والعملية. بينما اختار 20\% من أفراد العينة ومعظمهم من المتقاعدين الحيادة، بعدم اختيارهم أي أي فاختاروا التوسط.

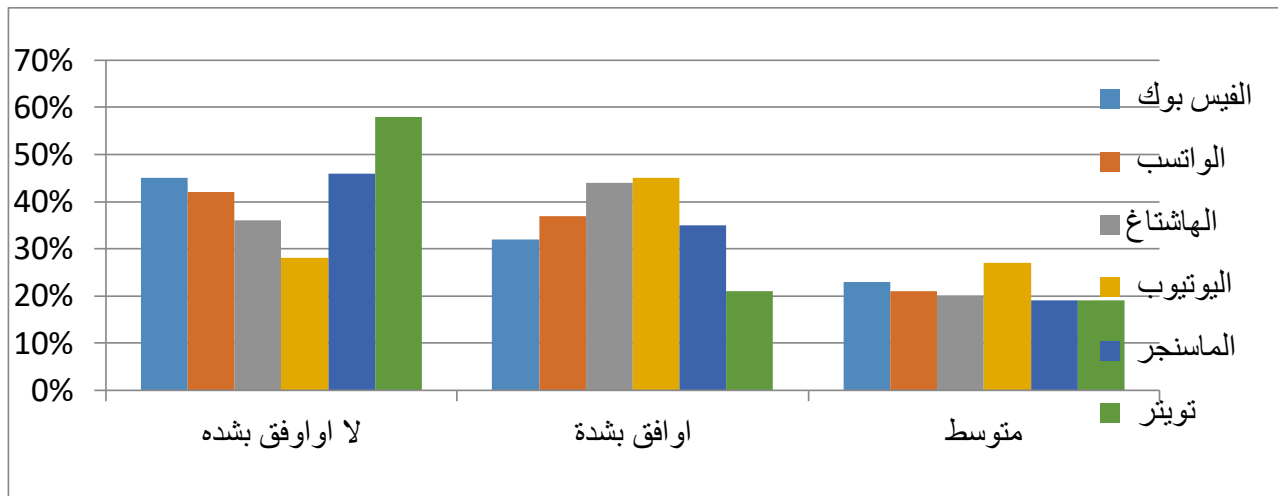

رسم بياني رقم (- )

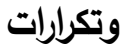
مجموع نسب سؤال الوسيلة التي لها علاقة كبرى بحجم الأخطار الصحية والنفسية والاجتماعية والتربوية. - - محور الأمراض والأثار الصحية والنفسية والاجتماعي ة المترتبة على الإدمان على وسائل النت: بالنظر إلى الرسم

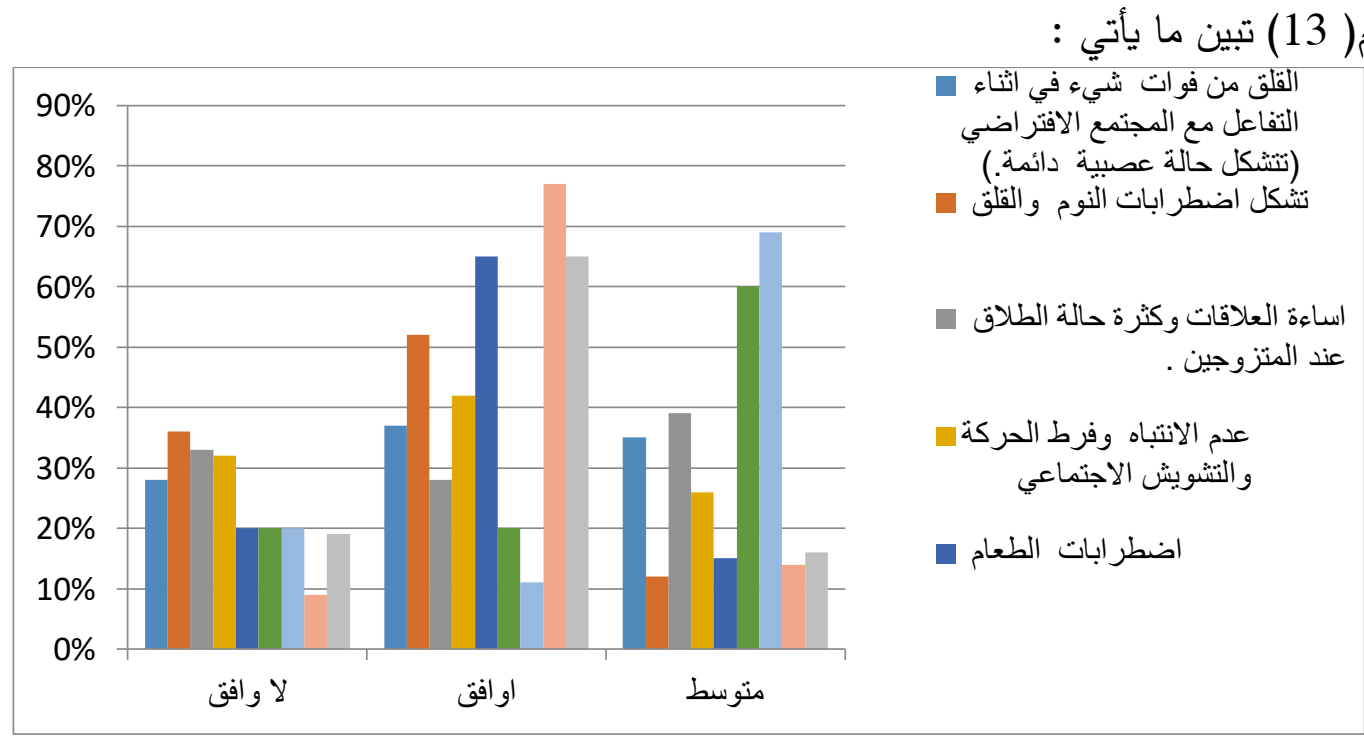

رسم بياني رقم(13) حالة وأعراض الأكتئاب النفسي والعزلة جراء الإدمان على النت ومستواها في الأردن 
- أقرّ 24\% من أفراد العينة في الأردن أن من الأمراض التي يصيب الفرد الأردني وقد بدأت بوادره تظهر جراء

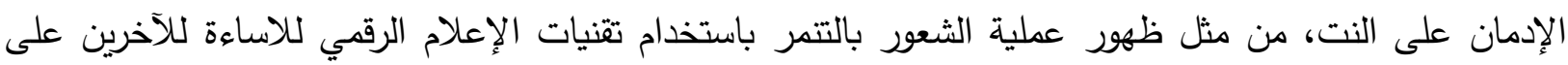
الأفراد والمؤسسات والإحساس بالاستقواء، وجاءت هذه النقرة بمتوسط حسابي 2.9 وانحراف معياري 823.

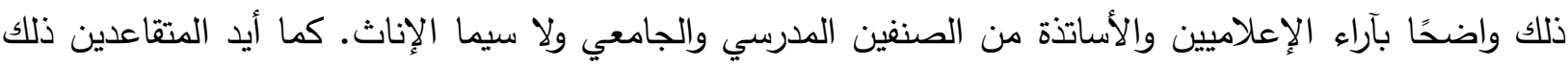

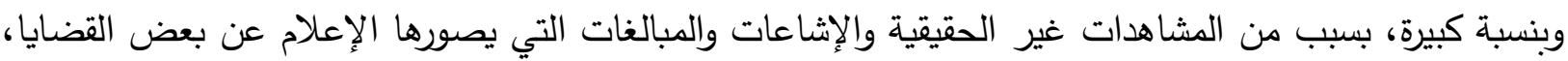

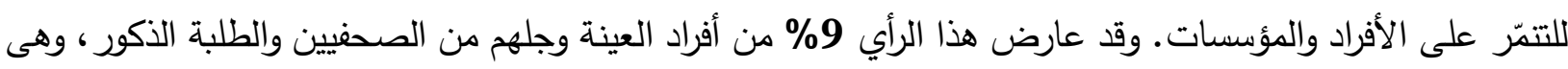

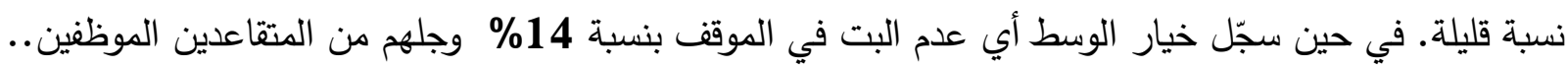

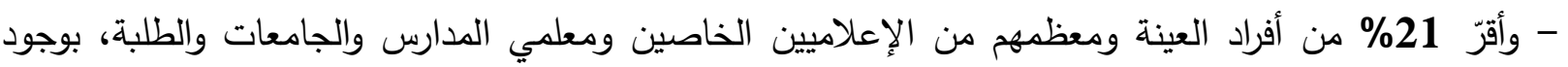

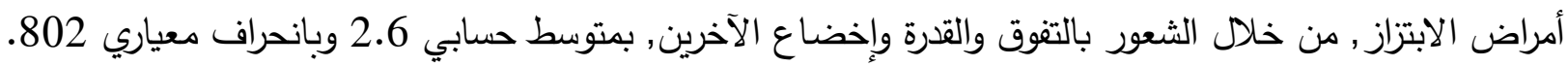

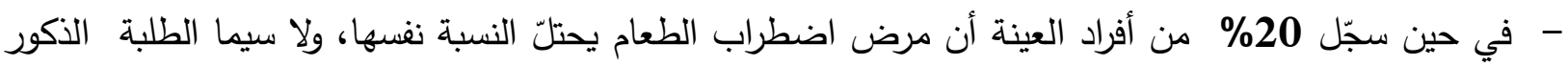

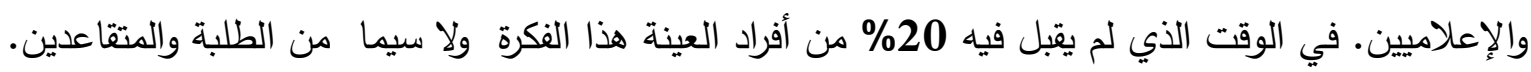

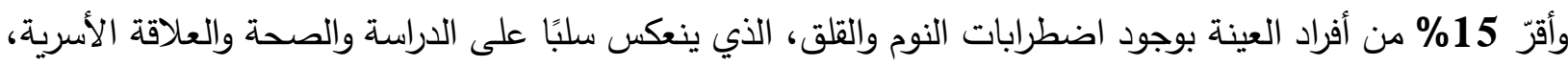

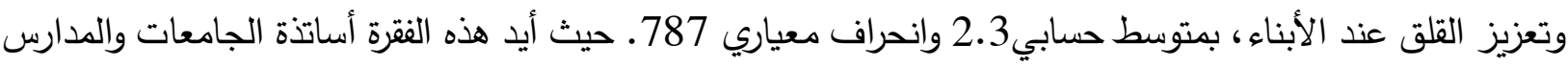

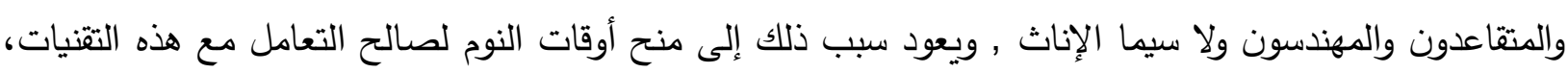

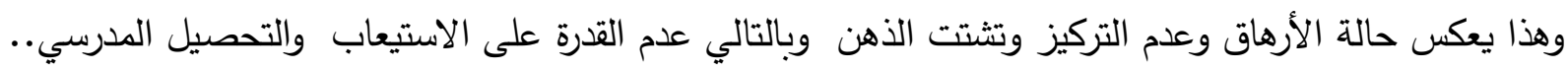

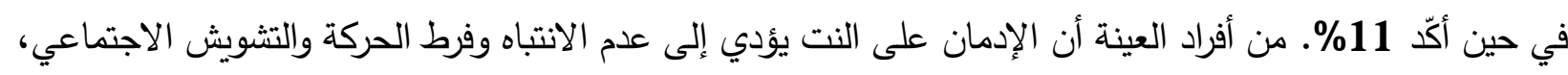

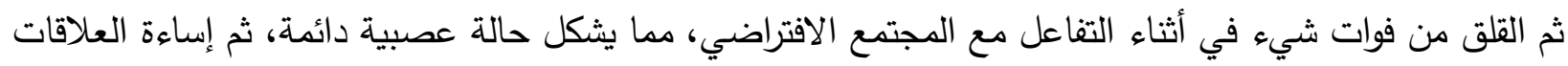

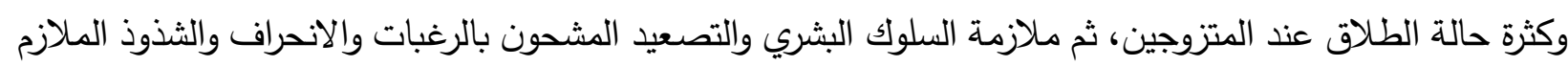

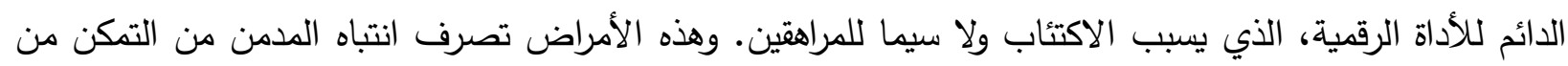

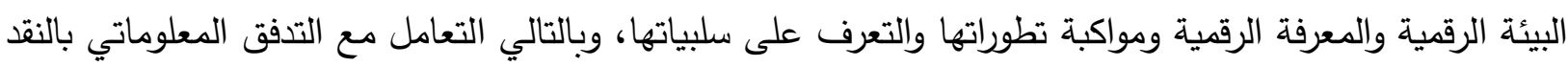
والتحليل واختيار الأفضل والملائم. وجاءت هذه الفترة بمتوسط حسابي 2.1 وانحراف معياري 772.

3-3-3 الخلاصة: أقرّت عينة الدراسة بضرورة تفعيل التثريعات الأممية للدفاع عن حقوق الإنسان من الدسيطرين على وسائل الإعلام

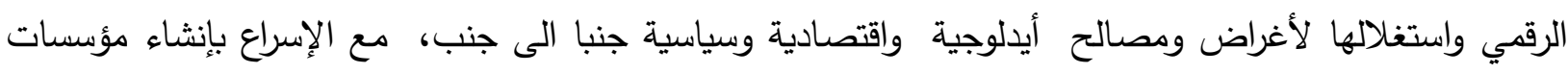
إعلامية كبرى تتبناها الأمم المتحدة؛ لتطبيق سياسات الإعلام الإنسانية وخلق توازن بين تدفقات الإعلام الدولي، وخلق

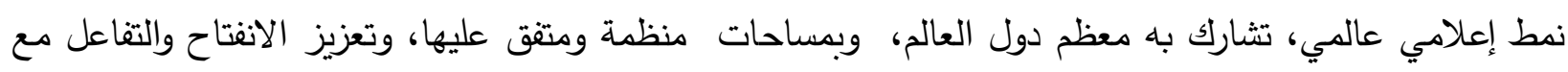

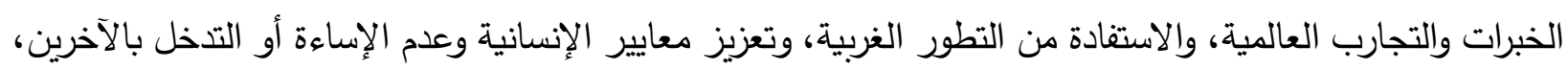

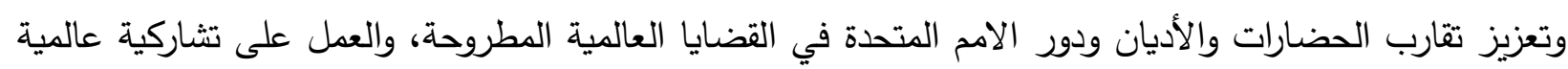
تجاه القضايا العالمية المشتركة.

لقد بينت نتائج الدراسة أن أفراد العينة أيدوا أن ثمّة استغلالًا لأدوات الإعلام الجديد لأغراض( أيدولوجية، دعائية,

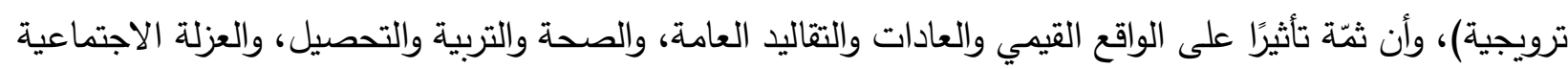


كما بينت ضرورة التعامل الموسع مع الوسائل الرقمية وضمن الأسس التربوية والصحية. وبينت النتائج أن الأردن ما زال خاليًا من حالات الإدمان التكنولوجي للنت، الذي يسببه الانكفاء الطويل على تقنيات الإعلام الرقمي وأدواته (النت), وما ينتج عنه من أمراض صحيّة كالاكتئاب والقلق والاضطراب النفسي، وقلة الحركة، والعزل الاجتماعي، وقلة الطعام، وقلق النوم , وضعف الثقة بالنفس والذات.

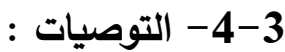

اعتماد التربية الإعلامية مقررًا للتدريس في مراحل العملية التعليمية المختلفة، ولا سيما في مراحل التعليم الابتدائي والثانوي والجامعي - (1)

دعوة المؤسسات التعليمية إلى التوظيف الأمثل لإمكانات مؤسسات الإعلام ووسائل الاتصال الجماهيرية في خدمة العملية التربوية التعليمية.

دعوة الإعلاميين والتربويين إلى التسيق بين قطاع التربية وقطاع الإعلام في تخطيط المحتوى الإعلامي التربوي،

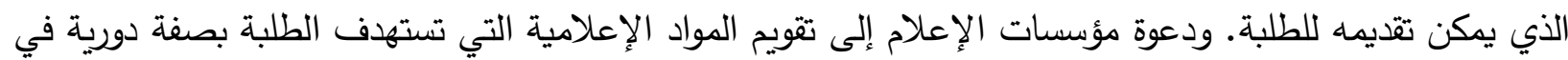
ضوء المعايير الإعلامية والتربوية والنفسية. تتمية التفكير الناقد، وإكسابهم المهارات التي تمكنهم من النظرة الموضوعية الفاحصة للأشياء والمواقف من خلال خطط وبرامج متخصصة في التربية الإعلامية، وبما يراعي القيم الدينية والثوابت الوطنية والأخلاقية، والتربية الإعلامية. تتمية الإحساس بالدين والوطن والانتماء؛ حتى يكون المتلقي ذا مناعة قوية أمام كل ما من شأنه أن يجرّده من انتمائه وأصوله وترسيخ المبادئ الأخلاقية في الإنسان. تفعيل دور الأسرة في الرقابة على الأبناء في حالات امتلاك الهواتف النقالة، لا سيما طلاب المدارس، وتوجيههم الوجهة الصحيحة أثناء استهلاك واستقبال ما تتتجه هذه الوسائل. ومنح الثقة بشكل معقول للثاب أو الفتاة، وتحديدًا في المرحلة العمرية فئة الثباب التي تعزز الثقة بالنفس وتمنحهم مستوى النقد والتحليل وحماية قيمهم وثقافتهم. على الآباء والأسر القيام بدور الإشراف الاقيق على ما تحويه هواتف أبنائهم من رسائل وصور وأرقام بالوسيلة التي يرونها مناسبة للسيطرة على الوضع، وتربية الأبناء على الحياء ومراقبتهم، والتثبت من الأخبار والأحكام قبل الإرسال، قبل ان تصبح شائعة.

\section{المصادر والمراجع}

البدراني، فاضل ، 2011، الثقافة الإعلامية العميقة”، والتربية الإعلامية والرقمية ، بغداد، مركز دراسات الوحدة العربية التقريرالسنوي، هيئة الاتصالات الأردنية, 2018 البنا، شيرين، الطويسي، باسم، التربية الإعلامية والمعلوماتية في الأردن، 2016 ، معهد الإعلام الأردني ، الأردن. جاك غولد سميث, متيم ، 2009، من يحكم الإنترنت أوهام بلا حدود، ط1، ترجمة فاطمة أبو غنيم ،هيئة أبو ظبي للثقافة والفنون. جنيف سويسرا. الاتحاد الدولي للاتصالات ، أدوات الماهرات الرقمية ،استراتيجية،2018. الخالدي، هاشم،2012, مدير عام وكالة أنباء سرايا، مقابلة مع الباحث، 19 ديسمبر/كانون الأول . 
http://elsada.net/67350/الخيول ،حارث محمد، تأثير تدريس التربية الإعلامية كمنهج للتتريس ، 2016، الإطلاع 2020/3/22

• الخطيب محمد، دور المدرسة في التربية الإعلامية"، المؤتمر الدولي الأول للتربية الإعلامية، وزارة التربية والتعليم

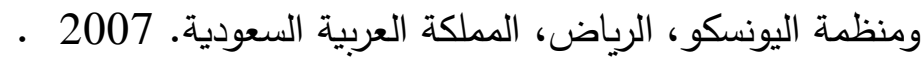

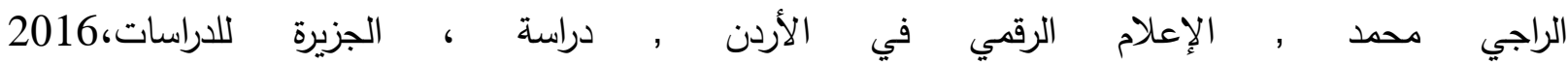

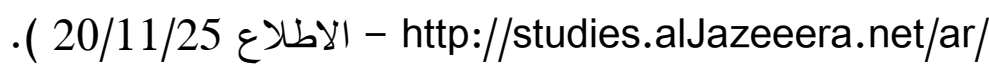

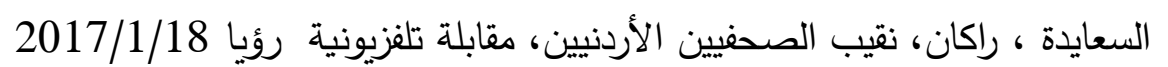
-https://www.almaany.com/ar/dict الثيرازي مجد الدين/متوفى 817 هـ، مفهوم التربية، قاموس المحيط، 20/3/26 الاطلاع في 2020/3/23) الإطلاع

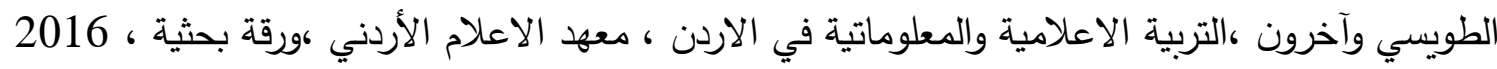

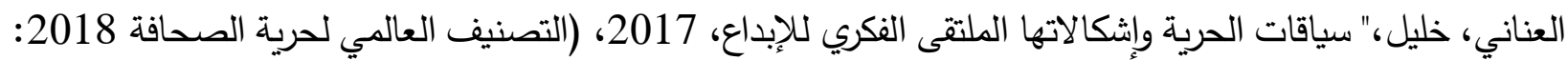
كراهية الصحافة تهدد الديمقراطيات"، مراسلون بلا حدود

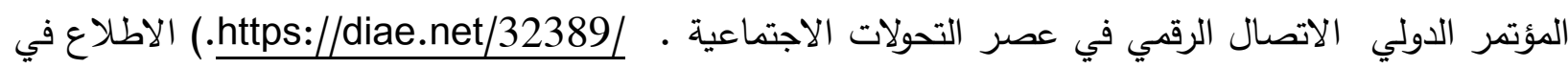
2020/3/22

عبد الحميد، محمد، الاتصال والإعلام على شبكة الإنترنت، عالم الكتب، القاهرة، 2007، ط 1، ص 30.

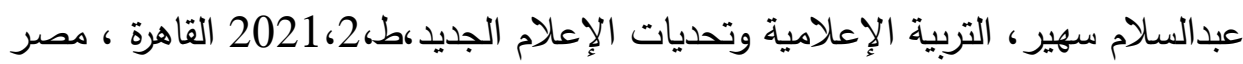

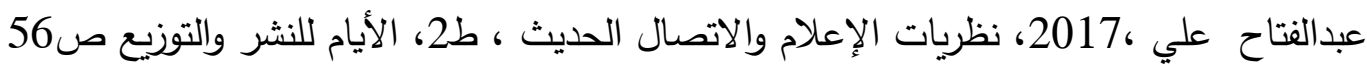

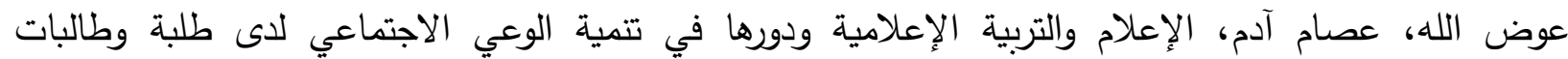

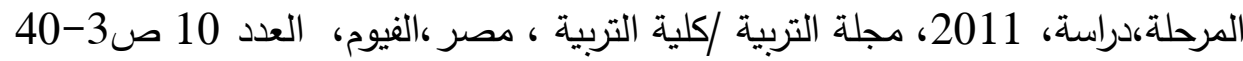

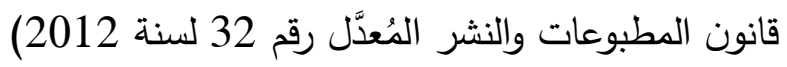
قانون التربية والتعليم 2020/11/25 الاطلاع 2http//:www; mohe.gov.jo/ar/gov,2018 المؤتمر الدولي الاتصال الرقمي في عصر التحولات الاجتماعية ،جامعة التكنولوجيأ ،الامارات ، عجمان -

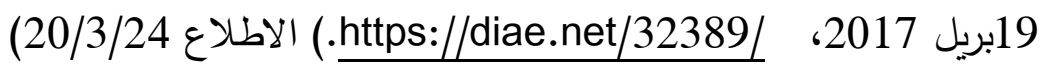

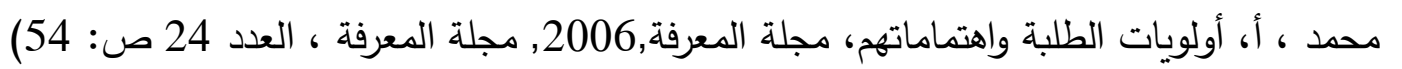

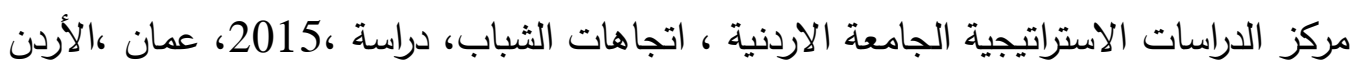

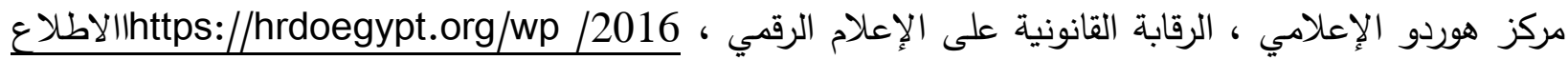
$\underline{20 / 11 / 22}$

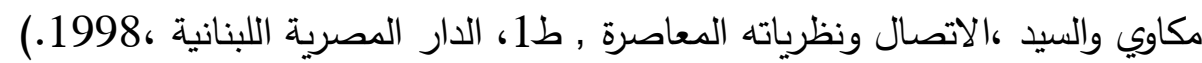

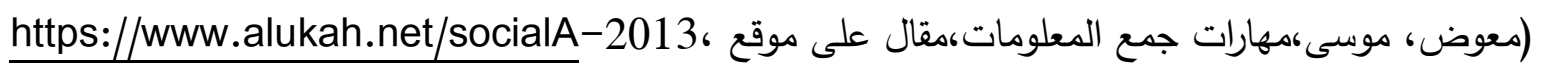

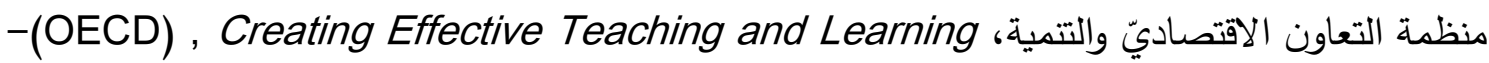
Environments موقع العرب، تعديلات قانون الصحافة ، 2020/3/24 https://alarab.co.uk2018/6/29 : - الاطلاع 2020) 
النذير، محمد ، الإعلام التربوي و التربية الإعلامية الرقمية ، دراسة مقاربة نسقية مفاهيمية ، مجلة الدراسات

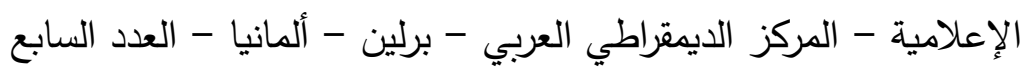

htt://www.interntworldststs.com/stst5.htm 2017, وزارة تكنولوجيا المعلومات, التقرير السنويك

$$
\text { 20/3/25: الاطلاع }
$$

وكالة سرايا مراقبون: عام سيء للحريات الإعلامية"،2015 ، 13 ديسمبر/كانون الأول 2015، ،تاريخ الدخول:

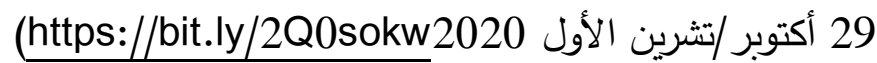

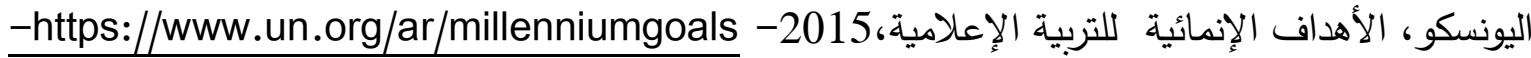

20/3/25 الاطنلاع

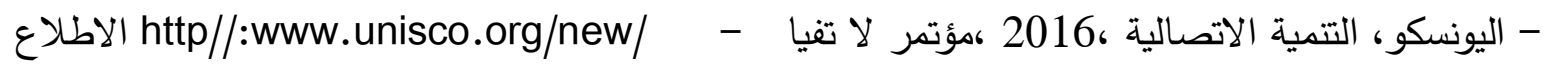
$20 / 3 / 24$

اليونسكو، بيان براغ ، التربية الإعلامية، 2003 -whttp //:www.unisco.org/education/media،- الاطلاع $20 / 3 / 24$

اليونسكو تقرير ، الدراية الإعلامية المعلوماتية

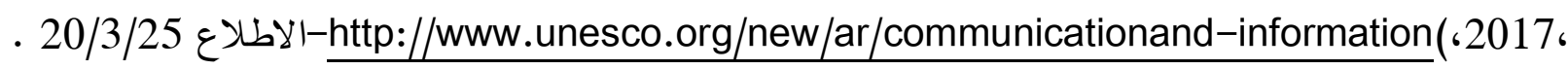
اليونسكو ، تقرير التربية الرقمية والمكتبات العامة ، مفهوم التربية الرقمية 201620/3/22-https://ar.unesco.org/themes/higher-education

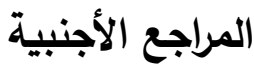

- Caroll, Jim. 2007. Ready, Set, Done. How to Innovate When Faster /s the New Fast.sandigo- us.

- E,Vitika, Ministry of Education and Culture (Finland). The New Core Curriculumm 201. HaylesJone, mediaecologies.wordpress,2018,sanuni,us.

- Gill, John.. 'When only Digital Delivery Will Do.' Times Higher Education2016.

- Jack g.shaheen, 1984, Arab TVAnimation and its impact on youth, university of ohio,p21

- UNESCO IPCD . 2015,Assessment of media a development in Jordan indenture IMD 